\title{
A Macroeconomic Framework for Quantifying Growth and Poverty Reduction Strategies in Niger
}

\author{
Emmanuel Pinto Moreira* and Nihal Bayraktar**
}

\begin{abstract}
This paper applies the dynamic macro framework developed by Agénor, Bayraktar, and El Aynaoui (2004) to Niger. As in the original model, linkages between foreign aid, public investment (disaggregated into education, infrastructure, and health) and growth are explicitly captured. Although the nominal exchange rate is fixed, the relative price of domestic goods is endogenous, thereby allowing for potential Dutch disease effects associated with increases in aid. The impact of policy shocks on poverty is assessed by using partial growth elasticities. Various policy experiments are performed, including an increase in the level of foreign aid, a reallocation of public investment toward infrastructure, and neutral and non-neutral cuts in tariffs. The simulations illustrate the dynamic trade-offs that these policies entail with respect to growth and poverty reduction in Niger.
\end{abstract}

*World Bank; and ${ }^{* *}$ Penn State University and World Bank. We are very grateful to PierreRichard Agénor for his assistance in developing the analytical structure presented in this paper, to Hinh Dinh for advice, discussions and suggestions, and to Samba Mamadou for helping us collect the data used in this study. The Policy Research Working Paper Series disseminates the findings of work in progress to encourage the exchange of ideas about development issues. An objective of the series is to get the findings out quickly, even if the presentations are less than fully polished. The papers carry the names of the authors and should be cited accordingly. The findings, interpretations, and conclusions expressed in this paper are entirely those of the authors. They do not necessarily represent the view of the World Bank, its Executive Directors, or the countries they represent. Policy Research Working Papers are available online at http://econ.worldbank.org. 


\section{Table of Contents}

I. Introduction

II. Country Background

III. The Model

1. Production of Goods

2. Education and Labor Supply

3. Income and Expenditure

4. Aid, Government Budget, and GDP at Market Prices

5. Balance of Payments and Foreign Debt

6. Market Equilibrium and Prices

7. Deficit Financing and Private Savings

8. Poverty Analysis

IV. Parameter Estimates and Calibration

1. Parameter Estimates

2. Calibration and Baseline Solution

V. Policy Experiments

1. Increase in Foreign Aid

2. Change in the Allocation of Public Investment

3. Cut in Tariffs

VI. Conclusions

References

Appendix A-List of Equations

Appendix B-Definition of Variables and Parameter Estimates

Figures and Tables 


\section{INTRODUCTION}

In a number of low income countries (LICs), Poverty Reduction Strategy Papers (PRSPs) have become a strategic framework for designing policies and actions for fighting poverty. They also serve as an anchor and framework for guiding donor assistance to LICs. However, many existing PRSPs have suffered from the lack of a quantitative analytical framework to assess the effects of poverty reduction strategies and evaluate progress in implementing them. Indeed, one of the key weaknesses identified in Niger's PRSP and its first PRSP Progress Report is the lack of a quantitative framework for analyzing the impact of policies implemented on growth and poverty, trade-offs entailed by alternative policy choices, and the potential impact of foreign aid on the economy.

This paper applies the dynamic macroeconomic framework developed by Agénor, Bayraktar, and El Aynaoui (2004) to Niger. As in the original model, key features of the present framework are the fiscal and supply-side effects of aid, as well as the stock and flow effects of public investment (disaggregated into education, infrastructure, and health). Public capital in health and infrastructure has a direct effect on output and the marginal productivity of inputs used in private production. Public capital in education also plays an indirect role in the production process, given that "raw" labor must be educated to become productive. At the same time, potential congestion effects associated with the use of public services are accounted for. The domestic (composite) good is imperfectly substitutable with the foreign good, and its relative price is endogenous. As a result, the model allows us to analyze potential Dutch disease effects that may be associated with large aid flows in a fixed-exchange rate economy such as Niger (through increases in domestic prices), in both the short and the long run. In addition, the model captures explicitly the link between aid and public investment, and possible adverse effects of large inflows of foreign assistance on tax effort. In the absence of a new household survey for Niger, the impact of policy shocks on poverty is assessed by using partial elasticities relating consumption growth to poverty, using a range of plausible estimates and the distribution-adjusted formula proposed by Ravallion (2004). The model (whose structure is summarized in Figure 1) is used to simulate a variety of policies that could be important for helping 
Niger design and quantify a medium-term strategy aimed at fostering economic growth and reducing poverty.

The remainder of the paper is organized as follows. Section II presents some background economic data on Niger. Section III describes the model. Section IV presents parameter estimates and the calibration procedure. Section $\mathrm{V}$ presents three sets of simulation results associated with an increase in foreign aid, a reallocation of government investment toward infrastructure, and a reduction in tariff rates. Section VI summarizes the main policy lessons of the analysis.

\section{COUNTRY BACKGROUND}

With a GNP per capita of US $\$ 200$ in 2003 , Niger is the second poorest country in the world. Poverty is widespread and according to the latest household survey available (1989-93), two-thirds (or 63 percent) of the population live below the poverty line, and one-third (34 percent) can be considered extremely poor. Social indicators and living conditions are extremely fragile and precarious (see Table 1). The UNDP Human Development Index ranked Niger $174^{\text {th }}$ out of 175 countries in 2003.

The economic structure is dominated by agriculture and uranium exports. The agriculture sector, which employs more than 80 percent of the economically active population, generates more than 40 percent of GDP and is highly vulnerable to periodic droughts and progressive desertification. In this context, economic growth and income are highly volatile (see Figure 2). Domestic savings, at slightly above 3 percent of GDP (the lowest within the WAEMU region) in 2003, are too low to meet Niger's enormous investment needs. The tax base is very thin and revenue amounted to 9.9 percent of GDP in 2003, one of the lowest in the region and far from the WAEMU target of 17 percent. Niger is thus highly dependent on foreign grants and loans, which on average were equal to more than 90 percent of domestic fiscal 
revenue between 2001-2003 ${ }^{1}$. Foreign borrowing and foreign aid (measured in percentage of GDP) have been volatile over the last decade, reflecting the political circumstances. They increased throughout the1990s and declined sharply in 19992000 as a result of political turmoil, and then resumed in 2001 following the restoration of democracy and donor reengagement.

During most of the 1970s, Niger experienced a sustained economic boom and prosperity owing to substantial increases in revenue from uranium sales and a sharp rise in aid disbursement. Real GDP growth reached around 14 percent in 1978. However, large declines in world uranium prices in the early 1980s, compounded by severe droughts, poor public finance management, and economic turmoil in Nigeria (Niger's main trading partner) brought on a serious economic crisis during most of the 1980s and the early 1990s. Uranium export earnings fell by half from a peak of CFAF110.0 billion in 1983 to CFAF50.3 billion in 1992, a decline equivalent to 9.0 percent of GDP in 1992. Real GDP growth fell from nearly 7 percent to -6.5 percent in 1992.

Against this background, the devaluation of the CFAF franc in January 1994 restored some degree of competitiveness to the economy. In this context, the authorities undertook a comprehensive reform program supported by an IMF Standby Agreement (1994-95) and a World Bank Economic Recovery Credit (1994). On the macroeconomic front, the program aimed at raising the revenue-to-GDP ratio, reducing the wage bill in proportion of revenue, and increasing the investment-toGDP ratio. On the structural front, the program focused on restructuring key public enterprises (electricity, water, and telecommunications), liberalizing the labor market, and continuing efforts to restructure the banking system. The outcomes of this reform program were not satisfactory. Although real GDP growth reached 4 percent in 1994, consumer prices, on an end-year basis, increased by 40.5 percent (as a direct result of the devaluation), and the external current account deficit (excluding official grants) deteriorated by over 6 percentage points, to 13.8 percent of GDP. In the budgetary

\footnotetext{
${ }^{1}$ Total foreign grants and loans amounted to CFAF139.1 billion on average over the period
} 
area, the revenue-to-GDP ratio fell from 7.3 percent in 1993 to an all-time-low of 6 percent in 1994. New arrears on internal and external payments were accumulated and there was a substantial overrun in the wage bill. Progress in the public enterprise sector was slow and the liberalization of the labor market was limited and the restructuring of the banking sector stalled.

The new military regime committed itself to restoring macroeconomic stability and speeding up the structural reform agenda. The reform program was backed by a new three-year loan under the IMF-enhanced structural adjustment facility (ESAF) covering the period 1996-99 (signed in June 1996) and two successive World Bankadjustment credits, the Public Sector Adjustment Credit (signed in March 1997), and the Public Finance Reform Credit (signed in October 1998). The results of this reform program were broadly satisfactory. Real GDP increased in 1996 and 1997 albeit at rates below that of population growth (mainly due to inadequate rainfall in many areas of the country). GDP growth rebounded to 10.4 percent in 1998, reflecting favorable weather conditions. Inflation remained moderate, in part because of food imports. On the fiscal front, the revenue-to-GDP ratio rose by a yearly average of 0.6 percentage point, reaching 8.9 percent in 1998, due to the successful implementation of important tax measures included in the program. Against the backdrop of improved control over spending, this revenue performance helped to reduce the overall budget deficit to an annual average of 7 percent of GDP during 1996-99, down from 9.4 percent in 1994-95. The external current account deficit (on a commitment basis, and excluding official transfers) declined in 1996-98 to an annual average of 6.5 percent of GDP, from 7.1 percent during 1994-95. A number of structural reforms were initiated in 1997, including the rationalization of the civil service and the payroll system. However, public enterprise reform was slow, mainly due to the resistance of powerful trade unions, weak technical and administrative capacities.

The macroeconomic situation deteriorated after the April 1999 coup. Real GDP growth fell to -0.6 percent in 1999. The overall fiscal deficit (cash basis, excluding grants) stood at 6.0 percent of GDP. The wage bill could not be contained

2001-03 while total domestic revenue during the same period was on average CFAF150.1 billion. 
and the Government accumulated large external and domestic arrears. The stock of domestic payment arrears amounted to CFAF295 billion (23.7 percent of GDP) atend $1999^{2}$.

It is in this context that the new democratically elected government took office in late 1999. It moved quickly in implementing a stabilization and structural reform program supported by a three-year IMF-PRGF facility and the World Bank Public Finance Recovery Credit (PFRC, September, 2000) followed by the first Public Expenditure Adjustment Credit (PEAC I, October 2001). The outcomes of the reform program were positive. In 2001, real GDP grew by 7.1 percent, spurred by exceptionally favorable weather conditions. Inflation was stabilized at 4.0 percent and the current account deficit (excluding grants) declined from 7.5 to 6.7 percent of GDP in 2002. The reform agenda aimed also at reducing poverty. To this end, an Interim PRSP was prepared and Niger reached the Decision Point under the Enhanced HIPC Initiative in 2000. This enabled the country to receive debt relief of the amount of US $\$ 520$ million in net present value (NPV) terms.

Since 2000, the Government's efforts have continued. In January 2002, a full PRSP was prepared as a strategic framework for the fight against poverty. The PRSP confirmed the Government's commitment to reducing the proportion of the population living in poverty by half by 2015 , as called for under the Millennium Development Goals adopted by the United Nations in 1999. The donor community endorsed the PRSP as a credible framework for their development assistance. The implementation of the PRSP has been satisfactory, as indicated by the Bank and Fund Joint Staff Assessment. Also, in April 2004, Niger reached the Completion Point under the Enhanced HIPC Initiative and benefited from an additional and exceptional debt relief (topping-up) in the amount of US\$142 million in NPV terms.

Economic growth has been sustained since 2000. Real GDP grew at an annual average of 5.1 percent over 2001-2003, with a strong recovery of 7.1 percent

\footnotetext{
${ }^{2}$ This figure represents the estimate of the Nigerien authorities. IMF staff estimated the stock of domestic arrears at CFAF124 billions at end-1999. The difference between the estimates is mainly due to definitions of arrears. A reconciliation exercise of the stock of domestic arrears will be carried out jointly between the Nigerien authorities and IMF staff in 2005.
} 
in 2001 compared with -1.0 percent over 1999-2000. It is worth noting that the solid growth performance was due not only to good weather conditions but also to the improvement in public finances, the increase in capital expenditure on infrastructure, and the implementation of structural measures to promote growth. Inflation, on a 12month basis, fell from 4.0 at end-2001 to 2.7 percent at end-2002 and -1.6 percent at end-2003 as a result of the implementation of continued prudent monetary policies at the regional level of BCEAO, tight fiscal policies, and the growth performance.

However, the current account deficit (excluding grants for budgetary assistance) has remained relatively high and stood at an annual average of 7.4 percent of GDP over 2001-03. In addition, the expected poverty-reducing effect of growth has not materialized. With a growing population rate of 3.1 percent (the highest in the world), income per capita barely increased by 1 percent. Poverty remains widespread. Available data indicate that the poverty headcount index was 63 percent in recent years. In the same time, inequality has not changed, with a Gini coefficient of 50.5 percent in $2001 .^{3}$

Foreign aid, measured by the levels of total net Official Development Assistance received by Niger over the past three decades has been volatile, reflecting changes in economic and political circumstances of Niger. Figure 3 displays the evolution of aid per capita to Niger since the 1960s. The figure shows that ODA per capita increased steadily during the decade of the 1960s and the first half of the 1970s. However, the levels of ODA were relatively marginal, reaching US $\$ 4$ per capita in 1965 and barely US $\$ 10$ per capita in 1972. During the mid-1970s and early 1980s, Niger received substantial flows of ODA. ODA per capita reached US $\$ 43$ in 1982 and then declined the following two years (1983-84), cut by more than 40 percent in 1984 compared to 1982, on account of the failure of the adjustment program. The flows of ODA increased during the second half of the 1980s, reaching a peak of US $\$ 52$ per capita in 1988 and US $\$ 51$ in 1990, a period marked by the Government's substantial efforts to adjust and carry out a

\footnotetext{
${ }^{3}$ It should be noted that there is significant uncertainty as to the exact measures of inequality and poverty in Niger. For instance, Milanovic (2003, p. 44) reports a Gini coefficient of 40.2, compared to the value of 50.5 cited in the text.
} 
comprehensive reform program supported by donors' assistance. Niger has then experienced a drop in external aid received, as evidenced by a sharp decline in net ODA per capita occurring in 1996 and 1999, as a result of political instability. ODA per capita reached a level of US\$17.8 in 1999, the lowest since 1973, reflecting the consequences of the April 1999 coup and the withdrawal of major donors from the country. Although external assistance has resumed since 2000, ODA provided to Niger has remained far lower than the 1980s and 1990s levels. Aid flows also remain extremely volatile and unpredictable. Overall, during the past three decades (19752002), Niger received a total of US $\$ 7,278.8$ million of ODA equivalent to about US $\$ 260$ million of ODA per year on average (of which US\$214.6 million or around 82 percent in the form of grants and the rest in the form of loans at concessional terms).

With regard to the composition of aid, food aid provided to Niger has been relatively modest and fluctuated sharply over the last three decades (see Figure 4). It averaged annually US\$13.1million over $1973-1980$ and then declined to US $\$ 11.2$ million during 1981-1990 and further declined to US\$8.0 million over 1991-2002. The share of food aid amounted to 5.0 percent of total ODA during the period 1973-2002 or a total amount of US $\$ 304.8$ million, equivalent to less than 1 dollar per capita on average over the past three decades. As a result, the share of nonfood aid, defined as total ODA grants excluding food aid, was about 95 percent of total ODA provided to Niger over the same period. It amounted to about US $\$ 5.9$ billion over this period, equivalent to US\$18 per capita on average over 1973-2002. It is worth noting that food aid has increased during the past three years, accounting for more than 7 percent of total ODA grants on average during 2000-2002, whereas nonfood aid has declined in particular in 1999, reflecting political and social turmoil. Despite this, nonfood aid has continued to be the largest share of ODA grants. ODA loans amounted to US $\$ 1,333.8$ million during the period $1960-2002$, equivalent to barely US $\$ 3$ per capita over the period for a total amount of ODA of US\$7,746.9 million (equivalent to US\$16.4 per capita) over the period.

A key feature of Niger's economy is the extreme dependence of the Government's resources on foreign aid. Figure 5 displays the evolution of foreign aid in percentage of tax revenue and government final consumption expenditure during 
the period 1975-2002. Two outstanding patterns emerge from the trends and relationships between these variables. First, aid in percentage of tax revenue has been extremely volatile over the last three decades, reflecting mainly the high variability of external assistance provided to Niger (as noted earlier). The ratio increased steadily over the period 1975-1984, reaching about 94 percent on average over the period. Over the period 1986-1993, net ODA further increased to account for more than 200 percent of tax revenue on average over the period. It has declined to a level of 174 percent of tax revenue on average over 1995-2002. However, given the relatively low level of tax revenue in Niger, foreign aid continues to play a key role in government spending and resources. Second, although foreign aid declined over the last three years compared with the early 1990s, since 2000 it accounts for more than 140 percent of tax revenue (143 percent in 2002) and more than 90 percent of government consumption. In addition, capital expenditure is mostly financed by external assistance: 75 percent of total capital expenditure (CFAF 80.1 billion) on average over the period 2000-2003 are financed by foreign aid. A critical issue to address is thus whether the strong reliance on external aid has led to a decrease in taxation efforts, creating a moral hazard problem, as discussed in the literature on fiscal response models (see Franco-Rodriguez (2000)). This question is particularly important given that an important part of agriculture sector has been "de-fiscalized", meaning that it operates tax-free. However, since 1994, the authorities have introduced several revenue-enhancing measures, which have resulted in a doubling of tax revenue in seven years from CFAF62.1 billion in 1995 to CFAF144.6 billion in 2002. As a result, the revenue-to-GDP ratio increased by more than 3 percentage points from 7.2 percent of GDP in 1995 to 10.6 percent in 2002. Yet, Niger's revenue performance remains weak and its revenue-to-GDP ratio continues to be the lowest within the WAEMU region. At 10.6 percent of GDP in 2002, it stood at 5 percentage points lower than the WAEMU average of 15.6 percent, and 7 percentage points lower than Benin's and Mali's performance, 17.1 percent and 17.2 percent, respectively (see Table 2).

During the 1970s, public and private investment increased sharply (particularly in mining, manufacturing, and construction), reflecting the launch of the exploitation 
of uranium deposits and the start of the uranium era. Huge investment flows were directed to mining operations ${ }^{4}$. Apart from a significant increase in the mid-1970s, from 3.9 percent of GDP in 1975 to nearly 14 percent of GDP in 1977, public investment has been declining in proportion of GDP over the period 1974-2002 (see Figure 6). It fell from 8.5 percent of GDP over the period 1975-1990 to barely 5 percent during 1991-2002, owing mostly to political instability (1996 and 1999), the use of government revenue to pay debt service obligations, and the shortfall in donor assistance. With regard to its composition, much of public investment goes to investment in infrastructure, that is, transportation, energy, and telecommunications (see Figure 8). Over the period 1970-75, public investment in infrastructure accounted for nearly 70 percent of total investment, while a marginal part of government investment efforts were directed to education and health sectors, with an average over the period of 9.5 percent and 6.4 percent, respectively, of total public investment.

The Government's investment policy relied mainly on continuous planning under which a four-year investment program was prepared annually. This policy placed heavy emphasis on the development of a transportation and communications network (mostly roads and bridges), with a view to strengthen the economic and administrative integration of the country and establish efficient access routes to the sea. ${ }^{5}$ The first half of the 1980s witnessed a shift in investment policy towards investment in education, which doubled in proportion of total investment from nearly 10 percent over 1970-75 to 20 percent over the period 1979-84. Investment in infrastructure has continued to decline throughout the period 1985-2002 mainly in favor of the health sector. The authorities' efforts to improve education and cope with precarious health conditions have continued over the past four years, supported by

\footnotetext{
${ }^{4}$ The mining operations were carried out by SOMAIR (Société des Mines de l'Aïr). Total investment of SOMAIR to launch mining operations at Arlit was estimated in 1970 to CFAF 13.5 billion, including costs of constructing the town at Arlit.

${ }^{5}$ The Government's investment program for 1970/71 and 1973/74 provided for total expenditure of CFAF 47.6 billion of which nearly 61 percent was allocated to transportation and communications, 15 percent to agriculture and livestock and barely 11 percent to public health and education. As a policy response to a General Survey of the transportation sector carried out in 1970, the Government designed a long-term program of actions aiming at building large roads, including the Unity Road (linking Niamey with Lake Chad) as well as making the Niger River navigable as far north as Niamey.
} 
donors' assistance and the use of HIPC resources for social sectors. In this context, investment in education and health has increased, accounting, respectively, for around 9 percent and 24.5 percent of total investment on average over the period 1999-2002. The Government's efforts to address supply-side constraints on schooling have resulted in improved basic education. Primary enrollment has increased, with the gross enrollment rate moving from 27 percent in 1995 to 42 percent in 2002. A number of new classrooms have been recently built, most of which are in rural areas and new teachers recruited. ${ }^{6}$ With regard to health conditions, the Government's efforts resulted in an improvement of both the quality and coverage of basic health care. The share of people living within 5 kilometers of a health care facility increased from 32 percent in 1994 to 47 percent in 2000. Despite this progress, education and health conditions still remain very precarious. Niger's literacy rate of 15 percent is one of the lowest in the world. Classrooms are overcrowded. The infant mortality rate is 156 deaths per 1,000 births, and the average life expectancy at birth is only 46 years. Barely 60 percent of the population has access to potable water, only 5 percent of the rural population has access to sanitation facilities, and less than half of the population has access to health services (see Table 1).

With regard to infrastructure, although it still accounts for the highest share of total public investment (40 percent on average over 1985-2002) the quality of infrastructure has remained quite low. Connectivity remains underdeveloped. All infrastructure networks (telecommunications, roads, energy, and water) are underdeveloped with coverage below sub-Saharan averages. A key issue is therefore how greater priority to public investment in basic infrastructure can foster growth and accelerate poverty reduction, while at the same time improve access to education and health services.

Private investment has followed the trend of public investment, declining over the first half of the 1980s, reflecting the end of the boom of the uranium sector and

${ }^{6}$ Between 2001 and 2002, more than 2,000 new classrooms were built, of which 86 percent are located in rural areas and 3,701 contractual teachers were hired in the context of the "volunteer" teacher program. 
the economic crisis that Niger experienced during that period. Declining investment opportunities in the mining sector resulted in reduced investors' interest. A slight increase in private and public investment has been observed since 2000, reflecting economic recovery, increased private capital inflows, and resumption of donors' financing of public capital expenditure. Nevertheless, both public and private investment have since then remained relatively flat (see Figure 7). Niger's economy still attracts very little foreign direct investment as the country remains a hard place to do business. The structural characteristics of the country constitute major impediments to business opportunities, including long distance from the sea and high cost of imports, lack of international competitiveness and vulnerability to external shocks, limited financial intermediation, low levels of human and institutional capacity, and poorly developed public sector institutions.

This review suggests that, despite improvements in living standards during the second half of the 1990s and early 2000s, reducing poverty remains a big challenge for Niger. Levels of human and infrastructure capital remain low. Given the low revenue mobilization and low levels of domestic savings, Niger can meet its dire need to increase investment to improve social conditions and reduce poverty only by recourse to foreign aid. In this regard, a key issue to address then is the role that foreign aid, and aid-funded increases in public investment, can play to accelerate growth and foster private investment (through "crowding in" effects). Related issues to consider are the possible trade-offs that may arise regarding the allocation of public investment between education, health, and infrastructure and the adverse incentive effect on tax collection and Dutch Disease effects associated with increases in foreign assistance. The model presented in the following section can be used to address this type of questions and derive policy recommendations regarding the "best use" (in a macroeconomic sense) of foreign aid. 


\section{THE MODEL}

As noted earlier, the framework that we develop for Niger in this paper follows in many essential aspects the model presented in Agénor, Bayraktar, and El Aynaoui (2004). As in the original formulation, we specify a one-sector, two-good model that accounts for the fiscal and supply-side effects of aid, as well as the supply- and demand-side effects of public capital formation. We, however, amend the original specification to better reflect some of the important characteristics of Niger's economy-such as a fixed nominal exchange rate as well as other relevant changes, such as a disaggregation of domestic taxes into direct and indirect taxes. We also drop the distinction between food aid and nonfood aid, given that the former component is a relatively small fraction of the external assistance received by Niger in recent years.

We begin by describing the production side, as well as population growth, the education technology, and the determination of labor supply. We then describe components of aggregate demand (consumption, investment, and imports), aid and the government budget, the balance of payments and foreign debt, the equilibrium condition of the market for domestic goods, the savings-investment balance, and the procedure that we follow (in the absence of an updated household survey) for assessing the effect of policy experiments on the poverty rate. A complete list of the model's equations is provided in Appendix A. A list of endogenous and exogenous variables, as well as parameter values, is provided in Appendix $B$.

\section{Production of Goods}

The economy produces one (composite) good, which is imperfectly substitutable to an imported good. Abstracting from intermediate input requirements, domestic production requires land, in quantity LAND, educated labor (which is defined below), LE infrastructure, KGhea and KGinf, respectively: 


$$
Y=Y(\text { LAND, LEP, KP, KGhea, KGinf), }
$$

where $\mathrm{Y}$ is net domestic output.

The area of land allocated to production is fixed and normalized to unity. Public capital in infrastructure (roads, telephone lines, electricity, and so on) improves the productivity of the private factors used to generate output, because it facilitates the production process. Public capital in health improves the quality of labor employed in production.

In order to account for differences in the degree of substitutability between inputs, we adopt a nested CES production structure. At the lowest level, the quantity of educated labor used in production, $\mathrm{LE}_{\mathrm{P}}$, and the stock of public capital in health, KGhea, are used to produce the composite input T, which is defined as "effective" labor:

$$
T\left(L_{P}, K G h e a, P O P\right)=A T \cdot\left[\beta T \cdot L^{-\rho T}+(1-\beta T)\left(K G h e a / P O P^{\theta H}\right)^{-\rho T}\right]^{-1 / \rho T},
$$

where $\theta H \geq 0$ and $\sigma T=1 /(1+\rho T)$ is the elasticity of substitution between $L_{P}$ and $\mathrm{Kghea} / \mathrm{POP}^{\theta \mathrm{H}}$. The stock of public capital is divided by the size of the population, $\mathrm{POP}$, to account for congestion effects in the provision of health services.

At the second level, "effective" labor is used, together with private capital, KP, to produce the composite input $\mathrm{J}$ :

$$
J(T, K P)=A J \cdot\left[\beta J \cdot T^{-\rho J}+(1-\beta J) K P^{-\rho J}\right]^{-1 / \rho J},
$$

where $\sigma \mathrm{J}=1 /(1+\rho \mathrm{J})$ is the elasticity of substitution between $\mathrm{T}$ and $\mathrm{KP}$.

At the third level, the composite input $\mathrm{J}$ and public capital in infrastructure, KGinf, are combined to give net domestic output: 


$$
Y\left(J, K g i n f, Y_{-1}\right)=A Y \cdot\left[\beta Y \cdot J^{-\rho Y}+(1-\beta Y)\left(K G \inf / Y_{-1}{ }^{\theta 1}\right)^{-\rho Y}\right]^{-1 / \rho Y},
$$

where $\theta I \geq 0$. The lagged value of output, $Y_{-1}$, is used here as an indicator of the intensity of use of public services in infrastructure. For a given value of $\theta \mathrm{I}$, the higher the scale of production, the greater the potential for congestion effects. A high degree of complementarity between the "congestion-adjusted" stock of infrastructure capital and private inputs in the production process can be obtained by imposing a low value for the elasticity of substitution $\sigma \mathrm{Y}=1 /(1+\rho \mathrm{Y})$.

Domestic output is allocated between exports, $\mathrm{X}$, and domestic sales, DOM, according to a constant elasticity of transformation (CET) function:

$$
Y=A D E \cdot\left[\beta D E \cdot X^{\rho D E}+(1-\beta D E) D O M^{\rho D E}\right]^{1 / \rho D E},
$$

where $\sigma D E=1 /(\rho D E-1)$, with $1<\sigma D E<\infty$ measuring the elasticity of transformation between exports and domestic sales.

The value of production is given by

$$
P Y \cdot Y=P D \cdot D O M+P X \cdot X
$$

where PD denotes the price of the domestic good, PX the domestic-currency price of exports, and PY the net output deflator.

Given these two equations, standard efficiency conditions imply that the ratio of exports to domestic sales is given by

$$
X / D O M=\{(P X / P D) \cdot[(1-\beta D E) / \beta D E]\}^{\sigma D E},
$$




\section{Population and Labor Supply}

Population grows at the constant exogenous rate, $\mathrm{n}$ :

$$
\mathrm{POP}=(1+n) \cdot \mathrm{POP}_{-1}
$$

Educated labor is produced from "raw" labor, LR, which grows at the same rate as total population, $\mathrm{n}$ :

$$
L R=(1+n) \cdot L_{-1}
$$

We specify a two-level nested CES structure to show the transformation of raw labor into educated labor. At the first level, the number of teachers on the government's payroll, $\chi \cdot \mathrm{LE}_{\mathrm{G}}$, and the stock of public capital in education, KGedu, are used to produce a composite public education input, $Z$, which is defined as:

$$
Z\left(L E_{G}, K G e d u\right)=A Z \cdot\left[\beta Z \cdot\left(\chi \cdot L E_{G}\right)^{-\rho Z}+(1-\beta Z) K G e d u^{-\rho Z}\right]^{-1 / p Z},
$$

where $\chi$ is the share of teachers in total educated labor in the public sector and $\sigma Z=$ $1 /(1+\rho Z)$ is the elasticity of substitution between $\chi \cdot \mathrm{LE}_{G}$ and KGedu.

At the second level, the transformation of raw labor into educated labor, LE, takes place through the education system, access to which is free of charge. The "production function" for newly-educated workers, $\Delta \mathrm{LE}_{\mathrm{N}}$, depends on the quantity of raw labor in the economy in the previous period, $\mathrm{LR}_{-1}$, as well as the composite public education input, Z:

$$
\Delta L E_{N}=A E \cdot\left[\beta E \cdot\left(L R_{-1}\right)^{-\rho E}+(1-\beta E)\left\{Z /\left(L R_{-1}\right)^{\theta E_{2}}\right\}^{-\rho E}\right]^{-1 / \rho E},
$$

where $0<\theta G<1$, and $\sigma E=1 /(1+\rho E) \geq 0$. The public education input is divided by the term $\left(L_{-1}\right)^{\theta E}$ in order to capture congestion effects (overcrowded classrooms, inadequate training and learning support, and so on) in the education system (see 
Agénor (2004b)). As long as $\theta \mathrm{E}>0$, raw labor has an indirect, negative effect on the production of educated labor.

Given the flow equation above, the total quantity of educated labor available in the economy, LE, is given by

$$
\mathrm{LE}=\mathrm{LE}_{-1}+\Delta \mathrm{LE}_{\mathrm{N}}
$$

With $L_{G}$ denoting the number of educated workers employed in the public education system, the stock of educated labor in production is thus

$$
L E_{P}=L E-L E_{G} \text {. }
$$

We also assume that wages are flexible, so that there is no open unemployment of educated labor. This assumption is consistent with much of the evidence for low-income Sub-Saharan African countries, which suggests that wages tend to be highly flexible, except in the public sector (see, for instance, Dabalen (2002)). ${ }^{7}$ To a large extent, this reflects the importance of the informal sector in these economies. Dorosh, Nssah, and Samba-Mamadou (1996), and Dorosh and Sahn (2000), also assume that (real) wages are fully flexible in their Computable General Equilibrium (CGE) models of Niger.

\section{Income and Private Expenditure}

Income from production accrues entirely to a representative household, who holds the totality of domestic public debt and receives interest payments on it. It also receives government wages and salaries (from educated workers employed in the education system), unrequited transfers from abroad, and pays interest on its foreign debt. Total income before taxes, YTOT, is thus:

\footnotetext{
${ }^{7}$ We account for the lack of wage flexibility in the public sector by treating both employment and (real) wages in that sector as exogenous (see below).
} 


$$
\text { YTOT }=\mathrm{PY} \cdot \mathrm{Y}+\mathrm{WG} \cdot \mathrm{LE}_{\mathrm{G}}-\mathrm{RP}^{*} \cdot \mathrm{ER}^{\mathrm{F}} \cdot \mathrm{FdebtP}_{-1}+\mathrm{RD} \cdot \mathrm{DdebtG}_{-1}+\mathrm{ER} \cdot \mathrm{UTR} \$ \text {, }
$$

where $\mathrm{RP}^{*}$ is the interest rate on private foreign borrowing, FdebtP the stock of private foreign debt, DdebtG the stock of domestic public debt, RD the interest rate on that debt, \$UTR the foreign-currency value of private unrequited transfers (assumed exogenous), and ER the nominal exchange rate, which is taken as fixed.

Disposable income in nominal terms, Ydisp, can be defined as

$$
\text { Ydisp = YTOT }- \text { DITAX, }
$$

where DITAX denotes direct tax revenue. ${ }^{8}$

Total private consumption in real terms, $\mathrm{CP}$, is defined as a constant fraction of disposable income:

$$
\mathrm{CP}=(1-\mathrm{s}) \cdot \mathrm{Ydisp} / \mathrm{PQT},
$$

where $0<s<1$ is the savings rate and PQT the tax-inclusive composite market price of goods sold domestically.

Private investment (as a share of GDP) is taken to depend on the rate of growth in net domestic output (to capture an accelerator effect), private foreign capital inflows (measured as a proportion of nominal GDP, NGDP), ER·FP/NGDP, and the stock of public capital in infrastructure, relative to output, $K G i n f / Y$, to capture complementarity effects: ${ }^{9},{ }^{10}$

\footnotetext{
${ }^{8}$ Production units in the model are owned by the aggregate household and are not accounted for explicitly. We therefore assume, for simplicity, that corporate income taxes are paid by the household as well. Thus, DITAX corresponds to the sum of personal and business income taxes.

${ }^{9} \mathrm{We}$ also tested for a possible debt overhang effect, by introducing in preliminary regressions the economy's total foreign debt over GDP, ER.FdebtTot/NGDP. This effect is potentially important for low-income countries. For instance, Pattillo, Poirson, and Ricci (2004) found a negative relationship between external debt and private capital formation in developing countries. However, the variable did not prove to be statistically significant for Niger.

${ }^{10}$ See Agénor (2004a, Chapter 2 ) for a review of the evidence on the complementarity between public investment and private capital formation.
} 


$$
P Q T \cdot I P / N G D P=I P\left(\left(\Delta Y / Y_{-1}\right)_{-2}, K G i n f / Y, E R \cdot F P / N G D P\right),
$$

where IP is real private investment, and the accelerator effect is assumed to operate with a two-year lag (see the estimation results below).

The stock of private capital evolves over time according to

$$
\mathrm{KP}=\mathrm{IP}_{-1}+(1-\delta \mathrm{P}) \cdot \mathrm{KP} \mathrm{P}_{-1}
$$

where $\delta \mathrm{P}$ is a constant rate of depreciation.

Abstracting from intermediate consumption and changes in stocks, total demand for goods sold on the domestic market, Qd, is given by the sum of private and public spending on final consumption and investment:

$$
Q d=(C P+C G)+(I P+I G),
$$

where $C G$ and IG denote real current non-interest government spending and investment outlays, respectively.

In standard Armington fashion, goods bought and sold on the domestic market, $\mathrm{Q}$, are aggregated through a CES combination of imports, $\mathrm{M}$, and domestic sales of the domestically-produced good, DOM:

$$
Q=A D M\left[\beta D M \cdot D O M^{-\rho D M}+(1-\beta D M) M^{-\rho D M}\right]^{-1 / \rho D M},
$$

where $\sigma D M=1 /(1+\rho D M)$ is the elasticity of substitution between domestic and imported goods.

The spending identity is given by 


$$
P Q \cdot Q=P D \cdot D O M+P M \cdot M
$$

where $P Q$ is the price of the composite good before taxes, and PM the domesticcurrency price of imports.

Given these two equations, first-order conditions imply that the demand for goods sold domestically is allocated between demand for domestically-produced goods and demand for imported goods according to

$$
M / D O M=\{(P D / P M) \cdot[(1-\beta D M) / \beta D M]\}_{D M}^{\sigma} .
$$

\section{Aid, Government Budget, and GDP at Market Prices}

The government collects taxes (on income, imports, and domestic sales of goods and services), and spends on salaries, goods and services, and interest payments. It also invests in education, health, infrastructure, and other items (such as research and development). It receives foreign aid, the grant component of which is accounted for "above the line" as a source of revenue for the government. The deficit is financed by domestic borrowing and foreign borrowing (concessional or not).

Total government spending in nominal terms, GTOT, is defined as

$$
\text { GTOT }=W G \cdot \mathrm{LE}_{G}+\mathrm{PQT} \cdot(\mathrm{CG}+\mathrm{IG})+\mathrm{RG} \cdot \mathrm{ER}^{\mathrm{F}} \cdot \mathrm{FdebtG}_{-1}+\mathrm{RD} \cdot \mathrm{DdebtG}_{-1} \text {, }
$$

where WG.EG is the government wage bill (where WG is the average or effective nominal wage and EG public employment of educated workers), CG is current noninterest expenditure on goods and services (excluding wages), IG is total public investment, FdebtG is the stock of foreign debt, $R^{*}$ the interest rate on foreign debt, DdebtG the stock of domestic public debt, and RD the interest rate on that debt. Both $R G^{*}$ and $R D$ are assumed exogenous. 
The government budget balance, GBAL, is given by

$$
\text { GBAL = TAX + AID - GTOT, }
$$

where TAX is total tax revenue in nominal terms and AID is foreign grants measured in domestic-currency terms. TAX is defined as

$$
\text { TAX }=\text { DITAX + INDTAX + tm·ER } \cdot \mathrm{PM}^{*} \cdot \mathrm{M}
$$

where DITAX (respectively INDTAX) denotes direct (respectively indirect) taxes, and tm is the tariff rate.

AID is defined as

$$
A I D=E R \cdot A I D \$
$$

where AID $\$$ is the foreign-currency value of foreign grants.

The stock of domestic debt is defined as

$$
\text { DdebtG }=\mathrm{DB}+\text { DdebtG }_{-1}
$$

where DB is the flow of domestic borrowing, assumed exogenous.

Total public investment, IG, is defined as the sum of investment in health, education, infrastructure, and "other" investment spending, IGoth, which represents (as noted earlier) outlays on items such as research and development:

$$
I G=I G e d u+I G h e a+I \text { inf }+ \text { IGoth } .
$$

Each component is given as a fixed fraction of total investment: 


$$
I G h=\kappa h \cdot I G,
$$

with $\mathrm{h}=\mathrm{edu}$, hea, inf, oth, and $\Sigma \kappa \mathrm{h}=1$.

Direct tax revenue is given by an "effective" tax rate times the tax base, which is total household income, YTOT. Moreover, the effective tax rate, DITXR, is taken to depend on its lagged value; the ratio of total government expenditure, GTOT, to nominal GDP, NGDP; and, in line with fiscal response models, on the ratio of aid to nominal GDP, in order to capture a possible adverse effect of aid on fiscal effort: ${ }^{11}$

$$
\text { DITAX = DITXR[DITXR }{ }_{-1},\left(\text { GTOT/NGDP) }{ }_{-1},\right. \text { AID/NGDP, (AID/NGDP)^2]·YTOT. }
$$

To capture a possible nonlinear effect of aid on tax effort, we introduce also a quadratic term in the aid-GDP ratio. For instance, if the coefficient of the linear term is positive, and that of the quadratic term negative, an increase in aid would at first raise the effective tax rate, but would eventually reduce it. Aid would therefore entail decreasing marginal returns, in terms of its impact on overall resources available to the government.

Indirect tax revenue is also given by an "effective" tax rate times the tax base, domestic sales, $P Q \cdot Q$. The effective tax rate, INDTXR, depends on its lagged value and (again in line with fiscal response models), the ratio of aid to GDP: ${ }^{12}$

$$
\text { INDTAX }=\text { INDTXR(INDTXR }-1, \text { AID/NGDP }) \cdot P Q \cdot Q .
$$

Current non-interest expenditure on goods and services, CG, is assumed to be constant as a proportion of GDP. ${ }^{13}$ Total public investment, also as a share of

\footnotetext{
${ }^{11}$ See Franco-Rodriguez (2000) for a review of fiscal response models. Gupta, Clements, and Tiongson (2003) studied the impact of aid flows (both grants and concessional loans) on government revenue in a group of 107 developing countries during the period 1970-2000. They found that grantsin contrast with concessional loans-tend to have an adverse effect on revenue mobilization.

${ }^{12}$ Preliminary regressions did not indicate a nonlinear effect of the aid-to-GDP ratio on the indirect effective tax rate; we found also no significant effect of the government spending-to-GDP ratio. We therefore excluded them from Equation (29).
} 
GDP, is taken to depend positively on the lagged value of the tax ratio (a measure of the government's capacity to raise domestic resources) and aid as a share of domestic output: ${ }^{14}$

$$
P Q T \cdot I G / N G D P=\operatorname{ig}\left[(T A X / N G D P)_{-1}, \text { AID/NGDP, }(A I D / N G D P)^{\wedge} 2\right] .
$$

We again introduce a nonlinearity in the relationship between aid and public investment, by adding the squared value of the ratio of the former variable to output in the equation. To the extent that the coefficient of the linear term is positive and that of the quadratic term is negative, foreign assistance would be positively related to public investment outlays only up to a certain level of aid, and would be negatively related thereafter. This specification allows us to capture (albeit in a rather mechanical way) the absorptive constraints that a large increase in aid may create in the institutional environment that is typical of many poor countries.

Stocks of public capital in education, health, and infrastructure are given by ${ }^{15}$

$$
K G h=I G h_{-1}+(1-\delta h) K G h_{-1}, \quad h=\text { edu, hea, inf }
$$

where $0<\delta h<1$ is a constant depreciation rate. ${ }^{16}$

${ }^{13}$ In preliminary regressions, we tried to relate CG to variables such as the tax-to-GDP ratio, aid as a share of domestic GDP (as suggested by fiscal response models), as well as the share of depreciation of the public capital stock in GDP, to account for maintenance outlays. However, we were unable to find a robust and stable relationship between these variables and CG. We therefore kept it exogenous.

${ }^{14}$ Clements et al. (2003), in a study of low-income countries, found that public investment is negatively related to the ratio of foreign debt service to domestic output, and that this adverse effect is nonlinear. They also found that urbanization and trade openness have a positive effect on the ratio of public investment to GDP in these countries. However, preliminary regressions indicated that none of these variables proved significant in the case of Niger.

${ }^{15}$ Note that, in the model, the category "other" public investment is not converted into a stock variable; as a result, it has only demand-side effects, unlike the other components of public capital formation. The reason for doing so is a practical one-in the data the category "other" consists of a highly heterogeneous set of outlays.

${ }^{16}$ In preliminary regressions, we attempted to link government spending on goods and services, CG, to "required" spending on maintenance of public capital, with the latter assumed to be proportional to depreciation, as measured by DEPR $=P Q \cdot \Sigma_{h} \delta h \cdot K G h_{-1}$. However, as noted earlier, we were unable to find a stable relationship relating CG to DEPR or other variables. 
From standard national accounts identities, nominal GDP at market prices is also given by

$$
\text { NGDP }=P Y \cdot Y+I N D T A X+t m \cdot E R \cdot P M^{*} \cdot M+P Q \cdot\left(\delta P \cdot K P_{-1}+\Sigma_{h} \delta h \cdot K G_{-1}\right)
$$

where the last term measures depreciation (at current prices) on private and public capital stocks. ${ }^{17}$

\section{Balance of Payments and Foreign Debt}

Measured in foreign-currency terms, the balance of payments is given by

$$
\begin{gathered}
\mathrm{PX}^{*} \cdot \mathrm{X}-\mathrm{PM}^{*} \cdot \mathrm{M}-\mathrm{RG}^{*} \cdot \mathrm{FdebtG}_{-1}-\mathrm{RP}^{*} \cdot \mathrm{FdebtP}_{-1}+\mathrm{UTR} \$ \\
+\mathrm{AID}+\mathrm{FG}+\mathrm{FP}-\Delta \mathrm{NFA}=0,
\end{gathered}
$$

where FP denotes private capital inflows (assumed exogenous) and $\triangle \mathrm{NFA}$ the change in net foreign assets of the central bank. The foreign-currency value of the stock of private foreign debt, FdebtP, is thus defined as

$$
\text { FdebtP }=F P+F_{\text {debtP }} \text {, }
$$

whereas the foreign-currency value of the stock of external public debt, FdebtG, is given by

$$
\text { FdebtG }=F G+\text { FdebtG }_{-1}
$$

with FG denoting the flow of government borrowing abroad. Total external debt, FdebtTot, is thus given by

${ }^{17}$ Our definition in equation (32) is somewhat of an approximation, because we do not account explicitly for subsidies and our depreciation rates are estimates. Nevertheless, it is consistent with the structure of the model. 


$$
\text { FdebtTot }=\text { FdebtP }+ \text { FdebtG } \text {. }
$$

Given that the nominal exchange rate is fixed, the balance of payments clears through adjustment in official reserves.

\section{Market Equilibrium and Prices}

Market equilibrium requires the equality between the total supply of goods on the domestic market and aggregate demand for these goods. This equilibrium condition therefore boils down to equality between supply and demand for the composite good, that is, equations (18) and (19):

$$
Q=Q d
$$

The price of the composite good before taxes, $P Q$, is a CES aggregation of the price of the domestically-produced good and the price of imports:

$$
\left.P Q=\left[\beta D M \cdot P D^{1-\sigma} D M+(1-\beta D M) \cdot P M^{1-\sigma} D\right]^{1 /(1-\sigma} D^{\prime}\right) .
$$

The tax-inclusive price of the composite good is thus given by

$$
P Q T=(1+I N D T X R) \cdot P Q .
$$

The domestic-currency price of exports, PX, is given by

$$
P X=E R \cdot P X^{*},
$$

where $\mathrm{PX}^{*}$ is the world price of exports (assumed exogenous).

The domestic-currency price of imports, PM, is defined as the product of the nominal exchange rate and the world price of imports, $\mathrm{PM}^{*}$ (assumed exogenous), inclusive of tariffs: 


$$
P M=(1+t m) \cdot E R \cdot P M^{*},
$$

where $0<\mathrm{tm}<1$ is the tariff rate.

Equations (5), (20) and (38) imply that

$$
P Y \cdot Y=P Q \cdot Q+P X \cdot X-P M \cdot M .
$$

\section{Deficit Financing and Private Savings}

The financing constraint of the government implies that

$$
-\mathrm{GBAL}=\mathrm{DB}+\mathrm{ER} \cdot \mathrm{FG},
$$

where GBAL is the government budget balance, given by equation (23). In the simulations reported below, we assume that the government finances its deficit through foreign borrowing, at the average interest rate $R G^{*}$. We therefore solve the above equation for $\mathrm{FG}$.

From the household budget constraint, private savings, SP, is given by

$$
\mathrm{SP}=\mathrm{Ydisp}-\mathrm{PQT} \cdot \mathrm{CP}=\mathrm{s} \cdot \mathrm{Ydisp} .
$$

Using equations (5), (13), (14), (15), (20), (22) to (24), (34), (44) and (45), it can be shown that the model imposes equality between private investment and private savings. This equation, however, is not independent from the rest of the system. It can therefore be either eliminated or used for consistency checks. 


\section{Poverty Analysis}

As noted earlier, there is not a recent household survey for Niger at the present time. Thus, the procedure proposed in the context of the Integrated Macroeconomic Model for Poverty Analysis (see Agénor, Chen, and Grimm (2004)) to link changes in consumption to poverty and assess the effects of policy shocks on the poor cannot be implemented. We therefore follow the methodology adopted by Agénor, Bayraktar and El Aynaoui (2004), which consists of relating directly the poverty rate (estimated for some base period) to the growth rate of consumption per capita, as derived from the model. We use three partial elasticity values: a "neutral" or central value of -1 , a value of -0.5 , and a value of -1.5 . In addition, we also use the "adjusted" elasticity formula proposed by Ravallion (2004, pp. 12-13). With a Gini coefficient equal to 50.5 (as reported earlier), this formula gives a partial growth elasticity of $-9.3^{*}(1-\text { Gini })^{\wedge} 3=-1.13$. Values above or below unity allow us to capture the case where growth is or is not distribution neutral--albeit in a crude way (it implies, in particular, constancy of the distributional effects over time). For instance, with a partial elasticity of -1.5 , a 2 percent growth rate in real consumption per capita with no change in distribution and with an initial poverty headcount index of 63 percent would lead to a fall in poverty by 3 percent per year, or by about 1.9 percentage points in the first year; the poverty rate will be halved in $n$ years, where $n$ is the solution of $63^{*}(1-0.019)^{\wedge} n=31.5$, that is, $n=36$ years. By contrast, with a "neutral" elasticity of -1.0 it would take 55 years, and with an elasticity of -0.5 it would take more than a century.

\section{PARAMETER ESTIMATES AND CALIBRATION}

In this section we report econometric estimates of some of the behavioral equations of the model and describe some features of the calibration procedure. 


\section{Parameter Estimates}

Using annual time series, we estimated the three "fiscal" regressions-those linking the effective direct rate to its lagged value, the government spending-to-GDP ratio, the aid-to-GDP ratio, and its squared term; the effective indirect tax rate to its lagged value and the aid-to-GDP ratio; and public investment to the tax revenue-toGDP ratio, the aid-to-GDP ratio and its squared term (equations (A29), (A30), and (A31) in Appendix A). The estimated coefficients are reported below. Student-t statistics are given in parentheses. In order to correct for serial correlation, we estimated these equations with autoregressive processes of order one and/or two, denoted $A R(1)$ and $A R(2)$ below, where needed. These coefficients are reported as well. All regressions are based on annual data for the period 1982-2002.

The regression with the effective direct tax rate as the dependent variable gives

$$
\begin{aligned}
\text { DITXR }= & -0.001+0.908^{*} \mathrm{DITXR}_{-1}+0.003^{*}(\mathrm{GTOT} / \mathrm{NGDP})_{-1}+0.052^{*} \mathrm{AID} / \mathrm{NGDP} \\
& (-0.139)(6.311) \quad(0.104) \\
& -0.279^{*}(\mathrm{AID} / \mathrm{NGDP})^{\wedge} 2 \\
& (-1.504)
\end{aligned}
$$

Adjusted $R^{2}=0.793 ;$ Durbin-Watson statistic $=1.912$

$A R(1)=-0.606(-2.829) ; A R(2)=-0.900(-3.888)$

These results indicate that the aid-to-GDP ratio itself does not have a highly significant positive effect on direct tax effort, but its squared term has a negative sign. This indicates that after some point, the effect of the ratio of aid to nominal GDP on the direct tax rate tends to fall. Even though the coefficient of the government spending-to-GDP ratio is not statistically significant, we included this variable because it has an expected positive sign. The coefficient of the lagged value of the 
effective direct tax ratio was found to be highly significant and relatively large, at 0.908 .

The estimated regression equation with the effective indirect tax rate as the dependent variable yields

$$
\begin{aligned}
\text { INDTXR }= & 0.008+0.706 * \text { INDTXR }_{-1}-0.029 * \text { AID/NGDP } \\
& (2.865)(7.717)
\end{aligned}
$$

Adjusted $\mathrm{R}^{2}=0.742 ;$ Durbin-Watson statistic $=1.861$

$$
\operatorname{AR}(1)=-0.350(-1.347)
$$

These results indicate that the lagged value of the dependent variable has a highly significant coefficient, which is also relatively large. The aid-to-GDP ratio has a negative and significant effect on the indirect tax rate, a result that appears to be consistent with an adverse effect of foreign assistance on collection effort. ${ }^{18}$

The regression equation with the share of public investment in percent of GDP as the dependent variable gives

$$
P Q T \cdot I G / N G D P=-0.174+1.449^{*}(\text { TAX/NGDP })_{-1}+1.549^{*} \text { AID/NGDP }
$$

\section{$-4.261^{*}(\mathrm{AID} / \mathrm{NGDP})^{\wedge} 2$}

$$
(-2.175)
$$

Adjusted $\mathrm{R}^{2}=0.553 ;$ Durbin-Watson statistic $=1.888$

$$
\operatorname{AR}(1)=0.527(1.762) ; A R(2)=-0.420(-1.679)
$$

\footnotetext{
${ }^{18} \mathrm{We}$ also tested for a nonlinear effect of aid. The coefficient associated with the squared term was found to be insignificant and was dropped from the final results.
} 
These results indicate that the tax revenue-to-GDP ratio and the ratio of aid to GDP have a positive and significant effect on the public investment-to-GDP ratio. Both coefficients are greater than unity. The coefficient associated with the squared value of the aid-to-GDP ratio is negative and also significant. Thus, foreign aid appears to be positively related to public capital formation only up to a certain level of aid, and is negatively related thereafter.

The last equation that we estimated relates to the share of private investment in percent of nominal GDP. The regression results are as follows:

$\begin{aligned} \mathrm{PQT} \cdot \mathrm{IP} / \mathrm{NGDP}= & 0.001+0.056^{*}\left(\Delta \mathrm{Y} / \mathrm{Y}_{-1}\right)_{-2}+0.083^{*} \mathrm{KGinf} / \mathrm{Y}+0.033^{*} \mathrm{ER} \cdot \mathrm{FP} / \mathrm{NGDP} \\ & (0.058)(2.099) \quad(1.413) \\ & -0.028^{*} \text { Dummy87 }-0.027^{*} \text { Dummy92_95 } \\ (-3.871) & (-4.042)\end{aligned}$

Adjusted $\mathrm{R}^{2}=0.710 ;$ Durbin-Watson statistic $=1.893$

$\operatorname{AR}(1)=0.829(2.723) ; \operatorname{AR}(2)=-0.353(-1.271)$

These results show that the rate of growth of real output (lagged two periods) and the ratio of the public capital stock in infrastructure to GDP have a positive effect on private investment. Thus, the data provide evidence of a complementarity effect of public capital in infrastructure on private capital formation. The ratio of private capital inflows to GDP is not significant but has the correct sign. We also included two dummy variables to capture the effects of sharp drops in private investment in Niger during the estimation period. Dummy87 is equal to 1 in the year 1987 and 0 otherwise, and Dummy92_95 is equal to 1 between 1992 and 1995 and 0 otherwise. Both of these dummy variables are statistically significant. ${ }^{19}$

\footnotetext{
${ }^{19}$ We tested for the effect of the current and lagged values of the external debt-GDP ratio, using linear and quadratic terms (to capture a possible nonlinear relationship), but both variables turned out to be either insignificant or to have an incorrect sign. They were therefore dropped from the final specification.
} 
All other parameters were determined either by using shares for the base period, by dwelling on the scant literature for Niger, or (when country-specific data were not available) by using plausible values for low-income developing countries in general-including the estimates compiled by Agénor, Bayraktar, and El Aynaoui (2004) for Ethiopia in a similar setting. The elasticities of substitution on the production side were kept at relatively low values. For instance, the elasticity of substitution between $\mathrm{T}$ and $\mathrm{KP}, \sigma \mathrm{J}$, was set to 0.3 ; the elasticity of substitution between LE and Kghea/POP ${ }^{\theta H}, \sigma \mathrm{T}$, was set to 0.3 ; and the elasticity of substitution between $\mathrm{J}$ and KGinf, $\sigma \mathrm{Y}$, was set to 0.4 . The elasticity of substitution between $\mathrm{LE}_{\mathrm{G}}$ and $\mathrm{KGedu}_{-1}, \sigma Z$, is equal to 0.2 . The shares of $\chi \cdot \mathrm{LE}_{\mathrm{G}}$ and $\mathrm{KGedu}_{-1}$ in the production of $Z$ are assumed to be equal to each other, thus $\beta Z$ is 0.5 .

Measures of congestion effects were difficult to estimate, given the lack of information for developing countries in general and Niger in particular. As a result, we used relatively low values to avoid putting undue weight on these parameters. Specifically, for the parameter capturing congestion effects in the education system, $\theta \mathrm{E}$, we chose a value of 0.4 ; for the parameter determining the strength of congestion effects in the provision of health services, $\theta \mathrm{H}$, we chose a value of 0.4 ; and for the parameter capturing congestion effects in infrastructure capital, $\theta \mathrm{I}$, we chose a value of $0.3 .^{20}$ Relatively small values were also chosen for the depreciation rates of the various capital stocks. For lack of better values, the rate of depreciation of public capital (education, health, infrastructure, and other), $\delta$, was set uniformly at 0.025 . The depreciation rate of the private capital stock, $\delta P$, was set at 0.04 , a common estimate in the literature.

The long-run elasticity of transformation in domestic production was set at 0.3 , whereas the long-run elasticity of substitution between domestic and imported goods was set at 0.4 . We also assumed that the allocation of private expenditure between these goods occurs gradually, with an adjustment parameter that captures a low propensity to substitute between domestic and imported goods in the short run. This 
can be viewed as a way of capturing "habit persistence". Similarly, total output and real private consumption were also assumed to follow a partial adjustment process.

\section{Calibration and Baseline Solution}

We calibrated the model for 2003 , the most recent year for which we were able to construct a complete set of macro accounts. Data on national accounts, fiscal accounts, balance of payments (based on IMF estimates), and OECD data were combined to produce a consistent set of estimates. ${ }^{21}$ Significant discrepancies appeared in the aid data between national sources, the OECD's DAC database, and the fiscal and balance-of-payments accounts provided by the IMF; we chose to use the OECD data, which are the most comprehensive, and adjusted the other information accordingly while keeping intact major equilibrium relationships. Capital stock data (both public and private) were derived using the perpetual inventory method, using the depreciation rates indicated earlier. In solving the model, we use the nominal exchange rate as the numéraire, and therefore keep its value fixed in all the experiments that are reported below.

Conducting policy experiments with the model requires building a baseline scenario. Given that the model uses 2003 as its base period, this requires in turn making a series of assumptions for the policy and other exogenous variables, over the period 2004-2015. The stock of land is assumed constant and normalized to unity. Population and the supply of raw labor are assumed to grow at the constant rate of 3.1 percent, in line with recent estimates of demographic trends in Niger. The quantity of educated labor employed by the public sector in the education system is assumed to remain equal, as a share of total educated labor, to the value observed in 2003. The shares of public investment in infrastructure, health, education, and other spending are also kept constant at their base period values (about 37 percent, for instance, for infrastructure). Domestic borrowing is projected as a constant share

\footnotetext{
${ }^{20}$ We checked the sensitivity of results to changes in the value of the congestion parameters such as $0.25,0.5,0.75$, and 1 . We found that the results are robust to changes in the parameters.

${ }^{21}$ These estimates, as well as the adjustments that we made, are described in an unpublished Appendix $\mathrm{C}$, which is available upon request.
} 
of GDP. Given its financing constraint, we assume (as noted earlier) that Niger borrows externally (at concessional terms) to close its budget gap. Thus, public foreign borrowing is determined residually to balance the government budget, given the assumption of a constant domestic borrowing-GDP ratio. Current, non-interest public spending is also kept constant as a share of GDP.

Foreign interest rates on private foreign borrowing and on domestic and foreign debt are all taken to be fixed at the average level observed in 2003. Foreign aid (measured in domestic-currency terms) is kept constant in proportion of GDP at the 2003 level (about 10.7 percent). Private capital inflows and private unrequited transfers (both measured in foreign-currency terms) are kept constant in per capita terms. Prices of imports and exports are assumed to grow at a constant annual rate, taken to be equal to 3 percent for the price exports and 0 for the price of imports. Thus, we expect Niger's terms of trade to improve significantly over time. Finally, the average effective wage in the public sector is assumed to grow at the rate of change of the after-tax composite market price, reflecting full indexation on the cost of living.

Solution of the model, which is performed with Eviews, requires normalization of each equation on one left-hand side variable. In most cases, the normalization is straightforward and based on the way the equations are presented in Appendix A. The order of solution for X, DOM, PD, PY, M and $\triangle \mathrm{NFA}$ is somewhat more involved and proceeds as follows. Identity (5) is used to determine the price of domestic goods, PD, whereas equation (21) is used to determine the quantity of domesticallyproduced goods, DOM. Given the production function (equation (4)), the allocation function between exports and domestic sales (equation (6)) is used to determine $X$, and equation (43) is used to determine PY. Imports, M, are determined from equation (20). Finally, the change in net foreign assets of the central bank, $\triangle N F A$, is residually determined by the balance of payment equation (equation (34)). Thus, the implicit assumption is that, given the closure rule of the government budget, Niger faces no external payments constraint. While this assumption may be viewed as optimistic and somewhat extreme (given management rules of foreign exchange reserves in the 
CFA franc Zone), it provides a convenient medium-term "benchmark" in the current international environment.

The baseline projections for the period 2004-2015 are shown in Table 3. The results indicated that, given our assumptions (which are essentially extrapolations based on recent trends), income per capita rises and poverty drops in Niger. The estimated poverty rate decreases in the best case (a consumption growth elasticity of -1.5) by 8 percentage points down to 55.4 percent in 2015 from an estimated 63 percent in 2003. In the worst case (a consumption growth elasticity of -0.5 ), the poverty rate drops by about 3 percentage points over the same period, down to 60.4 percent compared to 63 percent in 2003. Obviously if the current trends were to be maintained, the prospects of reducing poverty would be rather bleak and the MDG of halving poverty by 2015 would prove elusive. Indeed, under the baseline projections and in the best case, it would take 47 years to reduce poverty by half in Niger. The rate of increase in composite prices is relatively low, but given the fixed nominal exchange rate and the constancy of import prices, the real exchange rate (defined as the ratio of the domestic-currency price of imports to the price of the domestic composite good) appreciates almost continuously. As a result, exports tend to fall over time. Imports decreases as well. The fall in tax revenue (as a share of GDP) leads to a fall in total public investment (also as a share of GDP) over time. Given the assumption of constant shares, all components of public investment fall over time, dampening the growth rate of output. The resulting fall in the public capital stock (measured in proportion of GDP) and the low growth rate of output combine to reduce private investment as a share of GDP from 5.6 percent of GDP in 2003 to 3.9 percent in 2015. The overall fiscal balance improves from -3.5 percent of GDP in 2003 to -2.6 percent in 2015; as a result, borrowing needs fall over time and (given the assumption of a constant ratio of domestic financing to GDP) so does the ratio of external debt to GDP. 


\section{POLICY EXPERIMENTS}

Using the scenario shown in Table 3 as our baseline case, we now examine three types of policy experiments: an increase in the level of foreign aid (which implies also changes in the level of public investment), a reallocation of public investment toward infrastructure, and a reduction in tariffs. The first experiment is in line with Niger's current PRSP, which emphasizes the need for an increase in foreign aid as a means to finance its development and poverty reduction strategy. It also acknowledges that Niger, the second poorest country on earth, will still depend on foreign aid over the next decade. Moreover, this experiment assumes that the additional foreign aid would be provided in the form of grants, shifting the mix of foreign aid from "loan-dominated" to "grant-dominated." This would also be in line with Niger's debt sustainability requirements.

The second experiment is motivated by the view that public infrastructure may be a key engine of growth in Niger, because of its potential positive externalities on the productivity of private inputs in general, and its complementarity effect on private investment. Among recent studies, for instance, Belloc and Vertova (2004), Clements et al. (2003), and Nubukpo (2003) all found that public investment has a positive impact on growth in low-income countries, with the latter study focusing specifically on WAEMU countries. The last experiment is motivated by the fact that, over the past three decades, policymakers in Niger have implemented a number of adjustments in the structure of tax rates, complemented by measures to improve tax administration and enhance tax collection. First, these measures have focused on increasing revenue in order to fill the revenue gap, meet revenue targets set forth in the context of IMF-supported programs, and comply with tariff harmonization requirement within WAEMU. Second, there has not been a quantitative assessment of the macro and micro implications of these revenue-enhancing measures, including their impact on disposable income per capita, growth and poverty. 


\section{Increase in Foreign Aid}

Our first experiment consists of a permanent increase in the aid-to-GDP ratio by 5 percentage points. The results are shown in Table 4 . As in all subsequent tables, they are displayed as percentage changes (for variables in levels) or absolute differences (for variables already in percentage form) from the baseline scenario.

The direct effect of the increase in aid is on the budget. Higher inflows of aid are associated with a permanent improvement in the fiscal balance, as it adds to government resources. The overall fiscal balance improves by about 3.2 percentage points of GDP on average over 2004-15, as a result of the increase in total revenue exceeding the increase in government expenditure. On the one hand, total revenue increases on average by about 4.7 percentage points of GDP over the period. On the other, additional revenue allows the Government to increase investment outlays. But because other components of expenditure (such as current spending on goods and services) do not change, the increase in total expenditure remains below the increase in revenue. As a share of GDP, total expenditure reaches a peak of 2.0 percentage points of GDP in 2005 and declines gradually to 0.8 percentage points by 2015 .

The increase in aid raises public investment by 2.1 percentage points in 2005 . The order of the rise then declines gradually over time, reflecting the decline in domestic tax revenue. The increase in public investment raises over time the stock of public capital in infrastructure which tends to raise private investment. By 2015, private capital formation increases by nearly 0.2 percentage points of GDP. Thus, the rise in public investment "crowds in" private investment through a complementary effect. The increase in private investment raises the stock of private capital over time; this, combined with the increase in the stock of public capital in infrastructure, tends to increase the marginal productivity of all other production inputs. As a result, the growth rate of output per capita at factor cost tends to increase gradually, reaching 0.6 percentage points by 2015 . 
The increase in private capital accumulation tends to raise the demand for educated labor, because private capital and educated labor are considered to be complementary factors (as measured by a low degree of substitution between them) in the production process. At the same time, the rise in public investment in education leads to an increase in the stock of capital in education and the "public education input", and therefore to a higher "output" of educated workers. But the ratio of educated workers to population stays almost the same due to lack of substitution between teachers and public capital stock in education.

The increase in the stock of public capital in health raises the efficiency of educated labor in production. At the same time, as noted earlier, the increase in public capital in infrastructure raises the marginal productivity of all production factors. The productivity gains associated with the combined effect of improved "effective labor" and increased marginal productivity contribute to higher domestic output, which in turn raises consumption spending and lowers poverty. The growth rate of real disposable income per capita increases cumulatively (in line with output), reaching 0.8 percentage points by 2015 . This leads to a rise in real private consumption per capita of the same magnitude. The impact on poverty reduction is quite significant. The poverty rate based on a partial elasticity of -1.5 falls by about 6.2 percentage points by 2015 . However, with an elasticity of -0.5 , the drop is only 2.3 percentage points (See Table 4 and Figure 9). Thus, to reduce poverty in half, say, between 2003 and 2015, the simulation suggests that external aid in proportion of GDP should be increased permanently by more than 10 percentage points if the partial growth elasticity of poverty is -1.5 , but by more than 30 percentage points if the elasticity is -0.5 . Clearly, even in the first scenario, absorption problems are bound to happen, making such increases in aid unfeasible in the very short run.

Throughout the simulation period, the real exchange rate depreciates as a result of a reduction in domestic prices. Indeed, the price of the composite good (the behavior of which reflects only the evolution of domestic prices, given that the domestic-currency price of imports does not change across simulations) falls quickly by an average of more than 0.5 percentage points over 2004-06. This declining trend 
continues throughout the period as a result of a supply response dominating the rise in aggregate demand associated with higher government spending and private expenditure. In turn, the fall in the price of domestic goods results in a shift toward exports over time, which increase by 2.2 percentage points (as a share of GDP) in the long run. At the same time, the buoyancy of domestic activity and higher private expenditure translate into a rise in imports. The increase in imports exceeds the expansion of exports, and the trade balance deteriorates.

A key feature of this simulation is that the potential Dutch Disease effect generally associated with an increase in aid does not materialize, not even in the short run. As discussed at length by Agénor, Bayraktar, and El Aynaoui (2004), an increase in aid has both supply- and demand-side effects, which imply that the net effect of a change in aid has, in general, an ambiguous effect on the real exchange rate-even in the short run. In the present case, the supply-side effects of the increase in public and private capital formation are large enough to offset the adverse effect of the rise in aggregate demand on prices, even in the short run-and despite partial adjustment in output. The net effect is a reduction in domestic prices, a real depreciation, and an increase in exports. However, as noted earlier, large increases in aid aimed at reducing poverty rapidly in the next few years may be unfeasible due to absorption capacity constraints. Moreover, it should be kept in mind that, in this simulation, the rise in investment (induced by foreign aid) has no effect on noninterest government spending; indeed, the ratio of that variable to GDP is constant over time. Thus, the recurrent costs associated with a higher level of public capital formation are not properly accounted for. By doing so, the induced increase in government spending could in principle increase pressure on domestic prices. In practice, however, the magnitude of the increase in recurrent expenditure may not alter significantly the results reported in Table 4.

\section{Reallocation of Public Investment}

Our second policy experiment assesses the impact of a 20 percentage point reduction in investment in "other" categories, which is fully reallocated to investment 
in infrastructure. Table 5 summarizes the results. The direct effect of a reallocation of public investment in favor of infrastructure is on private investment, which increases in the long run by an average of nearly 0.2 percentage points of GDP over 20122015. This complementarity effect is not large but it does translate into an increase in output growth per capita of about 0.3 percentage points by 2015. But the increase in real disposable income and consumption per capita is only about 0.1 percentage points of GDP by 2015. As a result, the impact on poverty is relatively small, regardless of the measure used. In the best case scenario, poverty is reduced by only 0.7 percentage point by 2015 (See Table 5 and Figure 10). The real exchange rate appreciates slightly in the medium and long run. This stimulates imports and weakens exports, resulting in a deterioration of both the trade and current accounts balances. However, the increase in imports is short-lived and as imports declined more rapidly than exports, this leads in the long run to an improvement in the current account.

The main lesson of this experiment is that a reallocation of public investment in favor of investment in infrastructure has both growth-enhancing and povertyreducing effects (albeit marginal), particularly through its complementarity effects on private investment. But these effects (as can be expected) tend to develop only gradually over time, and in the specific case of Niger the magnitude of the complementarity effect (as estimated on past data) does not appear to be large.

\section{Reduction in Tariffs}

We now consider a permanent cut of 10 percentage points in Niger's effective tariff rate. We first examine the case where the cut is non-neutral. We then study the case where the authorities offset the adverse revenue effect of lower tariffs by an increase in either direct or indirect taxes. 


\subsection{The Non-Neutral Case}

Table 6 shows the results associated with a non-neutral cut in tariffs. The first direct effect of the cut on the budget is a fall in revenue: taxes collected on imports fall by an average of 2.5 percentage points of GDP over the first three years (200407). This decline continues throughout the simulation period, reaching on average 2.1 percentage points of GDP during 2013-15. As a result, total government revenue including grants falls, by an average of 2 percentage points of GDP over 2004-07 and by about 0.5 percentage points of GDP over 2013-15. This leads to a widening of the fiscal deficit by 2.2 percentage points of GDP in the first year of the simulation period. However, because some components of government expenditure are adjusted to reflect lower revenue (namely, public investment), the magnitude of the increase in the deficit declines over time, to -0.3 percentage points of GDP in 2015.

The second direct effect of the decrease in the tariff rate (which makes foreign products cheaper) is on imports of goods and non-factor services. However, because of the partial adjustment that we impose on the reallocation of spending, the increase in import volumes does not occur immediately. Instead, imports increase gradually, after falling initially. The reason is that, at first, domestic prices fall by significantly more than the domestic-currency price of imports-thereby offsetting the effect of the reduction in tariffs on relative prices. Over time, however, domestic prices start increasing, and the volume of imports begins to rise-although at a relatively moderate rate throughout the simulation period. In fact, given the changes that occur in relative prices, imports in nominal terms fall initially by 0.5 percentage points of GDP and remain below the baseline value at the end of the simulation period. At the same time, exports tend to fall, as a result of the gradual appreciation of the real exchange rate, following a sharp initial depreciation due to the drop in the price of the composite good. Both factors combine to lead to growing external trade imbalances over time.

The decline in the tariff rate has a negative long-run effect on growth, essentially because the fall in revenue puts downward pressure on public investment, 
thereby reducing over time the productivity effect and (to a lesser extent) the complementarity effect of public capital in infrastructure on private production and capital formation. As a percentage of GDP, however, private investment falls by about 0.2 percentage points in the long run. At the same time, the tariff cut has a positive, albeit short-lived, indirect income effect, resulting from the sharp fall in the composite good price in the first year of the simulation period. The rise in real private consumption per capita persists until 2008. Thus, poverty drops, by about 1.2 percentage points at the end of the simulation period with an elasticity of -1.5 , and by 0.4 percentage points with an elasticity of -0.5 (See Table 6 and Figure 11).

\subsection{The Neutral Case: Adjustment in Direct Taxation}

Consider now the case where the effect of the tariff cut on revenue is offset, ex ante (that is, at initial baseline values), by an increase in direct taxation. Given the magnitude of the reduction in the effective tariff rate, this requires an increase in the direct tax rate of 5.2 percentage points.

The results of this simulation are summarized in Table 7 . The direct effect of this "compensated" shock is an increase in domestic taxes that is higher than the decrease in indirect taxes on imports. After increasing only by 0.06 percentage points of GDP in 2004, total revenue increases by 1.7 percentage points of GDP by 2015 . The initial low level of increase in revenue leads to a reduction in public investment in the first two years of the simulation period, and total expenditure initially falls. It then starts increasing, in line with the increase in government resources, reaching 0.7 percentage points of GDP by 2015. As a result, the fiscal balance improves continuously over time, exceeding its baseline value by about 1 percentage point of GDP by 2015.

The combined effect of a decrease in the tariff rate and an increase in the direct tax rate is an initial sharp decline in the price of the domestic good (and thus the composite price, despite the reduction in the domestic-currency price of imports resulting from the tariff cut), as in the non-neutral case. The composite price then 
increases from 2006 onward but at a relatively low rate, leading to a relatively modest appreciation of the real exchange rate in the long run, again as before. The key difference with the previous scenario, however, comes from the behavior of real disposable income. Although it rises significantly (given the sharp drop in the composite price) relative to the baseline scenario, the magnitude of this rise is much lower than in the non-neutral case. The reason is, of course, the increase in direct taxation. In turn, the increase in private consumption per capita is significantly lower than before, implying that poverty falls initially by much less, and ends up slightly higher by 2015, regardless of the elasticity used (See Table 7 and Figure 12). In contrast to the non-neutral case, the effect on output growth is positive (albeit small). The key reason is that in the present case total revenue increases gradually over time; as a result of the increase in domestic resources, public investment rises as well. In turn, the productivity effect of public capital in infrastructure tends to raise gradually the growth rate of output per capita, which increases in the long run by 0.1 percentage point.

\subsection{The Neutral Case: Adjustment in Indirect Taxation}

Finally, we consider the case where the effect of the tariff cut on revenue is offset, ex ante (that is, at initial baseline values), by an increase in indirect domestic taxation. Given the magnitude of the reduction in the effective tariff rate, this requires a 4.4 percentage point increase in the indirect tax rate on domestic sales of goods and services.

The results of this policy experiment are summarized in Table 8. Again, the increase in indirect domestic taxes falls short of the decrease in tariff revenue, leading to a fall in total revenue in 2004 and 2005. From 2006 onward, however, the increase in domestic taxes exceeds the fall in tariff revenue. Total revenue increases gradually, reaching 0.6 percentage points of GDP by 2015 . The initial drop in public investment is also large and persistent. The price of the composite good falls and, given the assumption of full indexation of public wages and salaries on the price of the composite good, that component of expenditure falls also. After an initial 
deterioration, the fiscal balance improves gradually over time, as a result of both the increase in revenue and the fall in total government spending.

Qualitatively, the effect of this experiment on domestic prices and the real exchange rate is similar to those obtained in the previous cases. The most important difference is that, as in the case of an offsetting change in direct taxation, the increase in real disposable income per capita (induced by the drop in the composite price) is of a lower magnitude than what was obtained in the non-neutral case. The reason, in the present case, is the increase in the after-tax price of the composite good, which lowers the purchasing power of income. As a result, real private consumption per capita rises by less, and poverty falls also by less. As shown in table 8 and figure 13, by 2015 the poverty rate falls by 0.1 percentage points with an elasticity of -0.5 (compared to 0.4 percentage point in the non-neutral case, see Table 6 ), and by 0.3 percentage points with an elasticity of -1.5 (compared to 1.2 percentage points in the non-neutral case). At the same time, real disposable income and consumption per capita rise by more under an adjustment in indirect taxes than under an adjustment in direct taxes; this explains why poverty falls in the first case and rises in the second. Thus, on the basis of these simulations, we are tempted to conclude that, if a revenue-neutral cut in tariffs must be implemented in Niger, a "propoor" policy would involve an offsetting increase in domestic indirect taxes, rather than a rise in direct taxes. However, this conclusion assumes implicitly that the distribution of taxes among income groups does not change, given that the model does not account for different classes of households (poor and non-poor).

\section{CONCLUSIONS}

This paper presented a macroeconomic model for Niger, based on the general framework developed by Agénor, Bayraktar, and El Aynaoui (2004). As in the original framework, the model captures the links between foreign aid, the level and composition of public investment, growth, and poverty reduction. The model is dynamic and is therefore particularly useful to examine the potential dynamic trade- 
offs that adjustment policies may entail-such as, for instance, between the short-run impact of higher public spending on education and infrastructure (on the budget, aggregate demand, and the real exchange rate) and the long-run effects on the productivity of labor and private capital, and thus on growth and poverty.

The first part of the paper provided a brief review of recent macroeconomic trends in Niger. The second part presented the model, whose key features include an endogenous real exchange rate, an explicit account of the various channels through which foreign aid affects the economy (direct effects on the budget and the balance of payments, but also indirect effects through tax effort and overall public investment), and the supply-side effects of public investment in health, infrastructure, and education. Constraints on aid absorptive capacity are accounted for by introducing a nonlinearity in the relationship between aid and total public investment, with foreign assistance being positively related to public capital outlays up to a certain level of foreign assistance, and negatively related thereafter. Thus, depending on parameter estimates, aid may entail significant diminishing returns. Poverty effects are captured by using partial growth elasticities, with "imposed" values of $-0.5,-1.0$, and -1.5 , as well as the distribution-adjusted elasticity based on the formula proposed by Ravallion (2004), which gives a value of -1.13 .

The third part of the paper presented parameter estimates and the calibration procedure. The last part presented three sets of simulation results associated with an increase in foreign aid, a reallocation of government investment toward infrastructure, and a reduction in tariff rates. A major lesson from the first experiment is that a 5 percentage point increase in the aid-to-GDP ratio would not allow Niger to halve poverty between 2004 and 2015. The magnitude of the required increase in aid would need to be roughly two times higher, more than 10 percentage points of GDP with a growth elasticity of poverty equal to -1.5 , and more than 30 percentage points of GDP with an elasticity of -0.5 . The magnitude of these inflows, however, would not only have destabilizing macroeconomic effects (including inflationary pressures, risk of excessive appreciation, and loss of competitiveness) but also lead to severe absorption constraints. Thus, the authorities may face a trade-off between seeking to 
reduce widespread poverty rapidly through huge inflows of aid, and coping with their potential short-term side effects. The challenge would then be to weigh the shortterm losses against the longer-term benefits in terms of strong and sustained economic growth for poverty reduction.

The second experiment focused on a reallocation of public investment toward infrastructure. A vast literature has shown that the composition of public investment does matter when assessing the potential impact of public investment on growth and poverty reduction. A key argument emerging from the literature is that investing in infrastructure is more prone to boost growth relatively rapidly than investing in education and health or other sectors. For instance, in a recent contribution, Larsen, Lan Pham and Rama (2004) argue that "economic growth is... the main engine for sustainable poverty reduction in Vietnam, and investment in infrastructure as its fuel." Their study concludes that "spending one additional point of GDP in infrastructure has led to a proportionate reduction of the poverty rate by roughly 0.5 percent. The impact is larger in poorer provinces. Poverty alleviation impacts are stronger in the case of transport investments, and even more so in the case of water and sanitation investments." Indeed, Niger lacks infrastructure in key areas, including roads, irrigation, electricity, storage and marketing facilities. This has constrained the development of an integrated economic base and hampered economic growth. The PRSP has rightly acknowledged the need to strengthen basic infrastructure in Niger, in particular in the areas of road transportation, water facilitation, electricity, and telecommunications. ${ }^{22}$ Our experiment shows that a reallocation of investment toward infrastructure has indeed a positive effect on growth over time, as the productivity and complementarity effects tend to develop.

The third experiment consisted of a permanent reduction in tariffs. We found that a non-revenue neutral tariff reform in Niger would have an adverse effect on the fiscal balance, although this effect would tend to decline over time. The growth effect, however, is unlikely to be large, to a large extent because the fall in revenue would

\footnotetext{
${ }^{22}$ However, the evidence shows that an important share of public investment (34 percent of total investment) is oriented to sectors other than infrastructure and social sectors.
} 
constrain the ability of the government to invest. We also found that a revenueneutral cut, involving an increase in direct taxes would lead to an increase in revenue and a significant improvement in the fiscal balance-and therefore to a more beneficial effect on growth. However, because the growth in disposable income and consumption per capita would be more limited, in the long run poverty would increase slightly. Finally, with an offsetting adjustment in indirect taxes, the reduction in poverty would be lower than in the non-neutral case, but larger than in the case of an increase in direct taxes. Keeping in mind that the model implicitly takes the distribution of taxes across households as constant, these simulation results would suggest that a revenue-neutral tariff cut involving an increase in indirect taxes is more "pro-poor" in Niger than a similar policy involving an increase in direct taxes.

The model can be used to perform a variety of additional experiments. For instance, it could be used to analyze the growth and poverty effects of external shocks, as for instance in Dorosh, Nssah, and Samba-Mamadou (1996) and Dorosh and Sahn (2000). Using Ravallion's (2004), corrected elasticity formula, it could also be used to study the impact of an autonomous reduction in inequality (as measured by a lower Gini coefficient) on the pace of poverty reduction in Niger, through its impact on the growth elasticity of the poverty rate. Although, by its very nature, the model does not explain income distribution endogenously, this experiment would be useful to assess the potential impact of redistribution on the poor. 


\section{Appendix A \\ List of Equations}

\section{Production of Goods}

$$
\begin{aligned}
& T\left(L_{P}, K G h e a, P O P\right)=A T \cdot\left[\beta T \cdot L_{P}^{-\rho T}+(1-\beta T)\left(K_{G h e a} / P O P^{\theta H}\right)^{-\rho T}\right]^{-1 / \rho T} \\
& J(T, K P)=A J \cdot\left[\beta J \cdot T^{-\rho J}+(1-\beta J) K P^{-\rho J}\right]^{-1 / \rho J} \\
& Y\left(J, K g i n f, Y_{-1}\right)=A Y \cdot\left[\beta Y \cdot J^{-\rho Y}+(1-\beta Y)\left(K G i n f / Y_{-1}{ }^{\theta l}\right)^{-\rho Y}\right]^{-1 / \rho Y} \\
& Y=A D E \cdot\left[\beta D E \cdot X^{\rho D E}+(1-\beta D E) D O M^{\rho D E}\right]^{1 / \rho D E} \\
& P Y \cdot Y=P D \cdot D O M+P X \cdot X \\
& \mathrm{X} / \mathrm{DOM}=\{(\mathrm{PX} / \mathrm{PD}) \cdot[(1-\beta \mathrm{DE}) / \beta \mathrm{BE}]\}^{\sigma D E}
\end{aligned}
$$

Population and Labor Supply

$$
\begin{aligned}
& \mathrm{POP}=(1+n) \cdot \mathrm{POP}_{-1} \\
& \mathrm{LR}=(1+\mathrm{n}) \cdot \mathrm{LR}_{-1} \\
& Z\left(L_{G}, K G e d u\right)=A Z \cdot\left[\beta Z \cdot\left(\chi \cdot L_{G}\right)^{-\rho Z}+(1-\beta Z) K G e d u_{-1}^{-\rho Z}\right]^{-1 / \rho Z}, \\
& \Delta L E_{N}=A E \cdot\left[\beta E \cdot\left(L R_{-1}\right)^{-\rho E}+(1-\beta E)\left\{Z /\left(L R_{-1}\right)^{\theta E_{2}}\right\}^{-\rho E}\right]^{-1 / \rho E} \\
& \mathrm{LE}=\mathrm{LE}_{-1}+\Delta \mathrm{LE}_{\mathrm{N}} \\
& L E_{P}=L E-L E_{G}
\end{aligned}
$$


Income and Private Expenditure

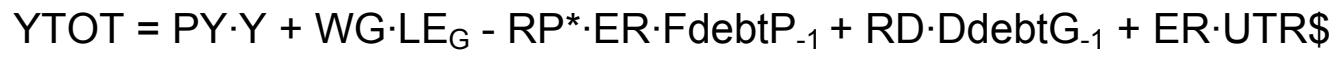

$$
\begin{aligned}
& \text { Ydisp }=\text { YTOT }- \text { DITAX } \\
& \mathrm{CP}=(1-\mathrm{s}) \cdot \mathrm{Ydisp} / \mathrm{PQT} \\
& P Q T \cdot I P / N G D P=I P\left(\left(\Delta Y / Y_{-1}\right)_{-2}, K G i n f / Y, \text { ER·FP/NGDP }\right) \\
& \mathrm{KP}=\mathrm{IP}_{-1}+(1-\delta \mathrm{P}) \cdot \mathrm{KP}-1 \\
& Q d=(C P+C G)+(I P+I G) \\
& Q=A D M\left[\beta D M \cdot D O M^{-\rho D M}+(1-\beta D M) M^{-\rho D M}\right]^{-1 / \rho D M} \\
& P Q \cdot Q=P D \cdot D O M+P M \cdot M \\
& M / D O M=\{(P D / P M) \cdot[(1-\beta D M) / \beta D M]\}^{\sigma}{ }
\end{aligned}
$$

Aid, Government Budget, and GDP at Market Prices

$$
\begin{aligned}
& \text { GTOT }=\text { WG } \cdot \mathrm{LE}_{\mathrm{G}}+\mathrm{PQT} \cdot(\mathrm{CG}+\mathrm{IG})+\mathrm{RG}^{*} \cdot \mathrm{ER} \cdot \mathrm{FdebtG}_{-1}+\mathrm{RD} \cdot \mathrm{DdebtG}_{-1} \\
& \text { GBAL }=\text { TAX + AID - GTOT } \\
& \text { TAX }=\text { DITAX + INDTAX + tm·ER } \cdot \mathrm{PM}^{*} \cdot \mathrm{M} \\
& A I D=E R \cdot A I D \$ \\
& \text { DdebtG }=\mathrm{DB}+\text { DdebtG }_{-1}
\end{aligned}
$$




$$
\begin{gathered}
I G=I \text { Gedu }+I \text { IGea }+I \text { Ginf }+ \text { IGoth } \\
I G h=\kappa h \cdot I G
\end{gathered}
$$

DITAX = DITXR[DITXR ${ }_{-1},\left(\right.$ GTOT/NGDP) ${ }_{-1}$, AID/NGDP, (AID/NGDP)^2]·YTOT (A29)

$$
\text { INDTAX = INDTXR(INDTXR }-1, A I D / N G D P) \cdot P Q \cdot Q
$$

$$
P Q T \cdot I G / N G D P=i g\left[(T A X / N G D P)_{-1}, A I D / N G D P,(A I D / N G D P)^{\wedge} 2\right]
$$

$$
K G h=I G h_{-1}+(1-\delta h) K G h_{-1}, h=\text { edu, hea, inf }
$$

$$
N G D P=P Y \cdot Y+I N D T A X+t m \cdot E R \cdot P M^{*} \cdot M+P Q \cdot\left(\delta P \cdot K P_{-1}+\Sigma_{h} \delta h \cdot K G_{-1}\right)
$$

\section{Balance of Payments and Foreign Debt}

$$
\begin{gathered}
\mathrm{PX}^{*} \cdot \mathrm{X}-\mathrm{PM}^{*} \cdot \mathrm{M}-\mathrm{RG}^{*} \cdot \mathrm{FdebtG}_{-1}-\mathrm{RP}^{*} \cdot \mathrm{FdebtP}_{-1}+\mathrm{UTR} \$ \\
+\mathrm{AID} \$+\mathrm{FG}+\mathrm{FP}-\Delta \mathrm{NFA}=0 \\
\text { FdebtP }=\mathrm{FP}+\mathrm{FdebtP}_{-1} \\
\text { FdebtG }=\mathrm{FG}+\mathrm{FdebtG}_{-1} \\
\text { FdebtTot }=\text { FdebtP }+ \text { FdebtG }
\end{gathered}
$$

\section{Market Equilibrium and Prices}

$$
\begin{gathered}
Q=Q d \\
P Q=\left[\beta D M \cdot P D^{1-\sigma}{ }_{D M}+(1-\beta D M) \cdot P M^{1-\sigma}{ }_{D M}\right]^{1 /(1-\sigma} D^{\prime}{ }^{\prime} \\
P Q T=(1+I N D T X R) \cdot P Q
\end{gathered}
$$




$$
\begin{gathered}
P X=E R \cdot P X^{*} \\
P M=(1+t m) \cdot E R \cdot P M^{*} \\
P Y \cdot Y=P Q \cdot Q+P X \cdot X-P M \cdot M
\end{gathered}
$$

\section{Deficit Financing and Private Savings}

$$
\begin{aligned}
-\mathrm{GBAL} & =\mathrm{DB}+\mathrm{ER} \cdot \mathrm{FG} \\
\mathrm{SP} & =\mathrm{s} \cdot \mathrm{Ydisp}
\end{aligned}
$$




\section{Appendix B \\ List of Variables and Parameter Estimates}

\section{Endogenous Variables}

\section{Variable Definition}

\begin{tabular}{ll} 
AID & Total aid measured in domestic-currency terms \\
AID $\$$ & Total aid measured in US dollars terms \\
CP & Total private consumption in real terms \\
DdebtG & Domestic public debt stock (direct borrowing) \\
DITAX & Direct tax revenue \\
DITXR & Effective direct tax rate \\
DOM & Domestic sales \\
FdebtG & Stock of public foreign debt \\
FdebtP & Stock of private foreign debt \\
FdebtTot & Total external debt \\
GBAL & Government budget balance \\
GTOT & Total government expenditure \\
IG & Real public investment \\
IGedu & Real public investment in education \\
IGhea & Real public investment in health \\
IGinf & Real public investment in infrastructure \\
IGoth & Real public investment in other categories \\
INDTAX & Indirect tax revenue \\
INDTXR & Effective indirect tax rate \\
IP & Real private spending on investment \\
J & Composite input from the supply of composite input T and private \\
& capital, KP \\
KGedu & Stock of public capital in education \\
KGhea & Public capital in health \\
KGinf & Public capital in infrastructure \\
KP & Private capital \\
LE, $\Delta$ LE & Total educated labor (stock and flow) \\
LEP & Quantity of educated labor used in private production \\
LR & Raw labor \\
M & Demand for imported goods (in real terms) \\
NGDP & Nominal gross domestic product \\
PD & Price of the domestic good \\
PM & Domestic-currency price of imports \\
POP & Size of the population \\
PQ, PQT & Composite price index (before and after indirect taxes) \\
PX & Domestic-currency price of exports \\
PY & GDP deflator \\
Qd & Total demand for goods sold on the domestic market (which \\
& \\
\hline
\end{tabular}




$\begin{array}{ll}\text { Q } & \text { includes both imports and domestically-produced goods) } \\ \text { SP } & \text { Domestic sales } \\ \text { T } & \begin{array}{l}\text { Private savings } \\ \text { "Effective" labor; composite input from the supply of educated }\end{array} \\ \text { TAX } & \text { labor, LE, and the stock of public capital in health, Kghea } \\ \text { X } & \text { Total tax revenue } \\ \text { Ydisp } & \text { Exports (in real terms) } \\ \text { Y } & \text { Households' disposable income in nominal terms } \\ \text { YTOT } & \text { Aggregate supply of domestic goods (in real terms) } \\ \text { Z } & \text { Total income before taxes } \\ \end{array}$




\section{Exogenous Variables}

Variable Definition

kh Share of public investment in $\mathrm{h}$ with $\mathrm{h}=\mathrm{edu}$, hea, inf, oth and $\Sigma \kappa \mathrm{h}=1$

$\chi$

CG

$D B$ Share of teachers in total educated labor in the public sector

Real public spending on consumption

$\triangle N F A$

ER

Flow of direct domestic borrowing

FG

Change in net foreign assets of the central bank

Nominal exchange rate

FP

Flow of government borrowing abroad

Private capital inflows

LAND

Land (normalized to unity)

$\mathrm{LE}_{G}$

$\mathrm{n}$

Quantity of educated labor employed by the public sector

$\mathrm{PM}^{*}$

Growth rate of population and raw labor

$P X^{*}$

World price of imports

$\mathrm{RD}$

World price of exports

$R G^{*}$

Interest rate on domestic public debt

Interest rate on public foreign debt

$\mathrm{RP}^{*}$

tm

Interest rate on private foreign borrowing

UTR\$

Tariff rate

WG

Private unrequired transfers

Average effective wage in the public sector 


\section{Parameters and Estimated Values}

Variable Definition

$\theta \mathrm{E} \quad$ Parameter capturing congestion effects in the education system

$\theta \mathrm{H} \quad$ Parameter determining the strength of congestion effects in the provision of health services

$\theta$ I Parameter capturing congestion effects on infrastructure capital

ADE Shift parameter in production of domestic goods $Y s$

ADM shift parameter in production of Qs

AE

Shift parameter in flow production of educated labor LE

AJ

AT

Shift parameter for composite input $\mathrm{J}$

AY Shift parameter for composite input $T$

$A Z$

Shift parameter for in the production function

Shift parameter for in the production of $Z$

$\beta D E$

Share parameter between exports EXP and domestic sales DOM in production of domestic goods Ys

BDM Share parameter between imports $M$ and demand for domestic goods DOM

$\quad \beta E \quad$ Share parameter between educated labor LE and public capital in education, Kgedu in flow production of LE

BJ Share parameter between the supply of $\mathrm{T}$ and the stock of private capital, KP in production of $\mathrm{J}$

BT Share parameter between the supply of educated labor, LE, and the stock of public capital in health, Kghea in production of $T$

$\beta Y$

$\beta Z$

$\delta h$

$\delta P$

$\rho D E$

$\rho D M$

$\rho E$

$\rho J$

$\rho T$

$\rho Y$

$\rho Z$

$S$

Share parameter between the supply of $\mathrm{J}$ and public capital in infrastructure, Kginf in production of $Y s$

Share parameter between $\mathrm{LE}_{\mathrm{G}}$ and $\mathrm{KGedu}_{-1}$ in production of $Z$

Depreciation rate of public capital with $\mathrm{h}=\mathrm{edu}$, hea, inf

Constant rate of depreciation of private capital

transformation parameter in production of domestic goods Ys

Transformation parameter in Qs

Substitution parameter in flow production of LE

Substitution parameter in production of $\mathrm{J}$

Substitution parameter in production of $\mathrm{T}$

Substitution parameter in production of domestic output

Substitution parameter in production of $Z$

Marginal propensity to save

$\sigma D E \quad=1 /(1-\rho D E)$; elasticity of transformation between exports and domestic sales

$\sigma D M=1 /(1+\rho D M)$; elasticity of transformation between imports and demand for domestic goods

$\sigma \mathrm{E} \quad=1 /(1+\rho \mathrm{E})$; elasticity of substitution between $\mathrm{LR}_{-1}$ and $\mathrm{KGedu} /\left(\mathrm{LR}_{-1}\right)^{\theta \mathrm{E}}$

$\sigma \mathrm{J} \quad=1 /(1+\rho \mathrm{J})$; elasticity of substitution between $\mathrm{T}$ and $\mathrm{KP}$ 
$\sigma \mathrm{T}$

$\sigma Y$

$\sigma Z$
$=1 /(1+\rho T)$; elasticity of substitution between LE and Kghea/POP ${ }^{\theta H}$

$=1 /(1+\rho Y)$; elasticity of substitution between $\mathrm{J}$ and $\mathrm{KGinf} / \mathrm{Y}_{-1}{ }^{\theta 1}$

$=1 /(1+\rho Z)$; elasticity of substitution between $\chi \mathrm{LE}_{G}$ and $\mathrm{KGedu}_{-1}$ 


\section{References}

Agénor, Pierre-Richard, The Economics of Adjustment and Growth, second ed., Harvard University Press (Cambridge, Mass.: 2004a).

- "Infrastructure, Public Education and Growth with Congestion Costs," unpublished, University of Manchester (December 2004b).

Agénor, Pierre-Richard, Nihal Bayraktar, and Karim El Aynaoui, "Roads out of Poverty? Assessing the Links between Aid, Public Investment, Growth, and Poverty Reduction," unpublished, World Bank (June 2004).

Agénor, Pierre-Richard, Derek Chen, and Michael Grimm, "Linking Representative Household Models with Household Surveys: A Comparison of Alternative Methodologies," Policy Research Working Paper No. 3343, World Bank (June 2004). Forthcoming in Adjustment Policies, Unemployment and Poverty: The IMMPA Framework, ed. by Pierre-Richard Agénor, Alejandro Izquierdo and Henning Jensen (Oxford: Blackwell Publishing).

Belloc, Marianna, and Pietro Vertova, "How Does Public Investment affect Economic Growth in HIPC? An Empirical Assessment," Working Paper No. 416, University of Siena (January 2004).

Clements, Benedict, Rina Bhattacharya, and Toan Q. Nguyen, "External Debt, Public Investment, and Growth in Low-Income Countries," Working Paper No. 03/249, International Monetary Fund (December 2003).

Dabalen, Andrew, "Alternative Views of the Labor Market in sub-Saharan Africa: A Review," unpublished, the World Bank (June 2000).

Dorosh, Paul A., B. Essama Nssah, and Ousmane Samba-Mamadou, "terms of Trade and the Real Exchange Rate in the CFA Zone: Implications for Income Distribution in Niger," in Economic Reform and the Poor in Africa, ed. by David E. Sahn, Clarendon Press (Oxford: 1996).

Dorosh, Paul A., and David E. Sahn, "A General Equilibrium Analysis of the Effect of Macroeconomic Adjustment on Poverty in Africa," Journal of Policy Modeling, 22 (November 2000), 753-76.

Franco-Rodriguez, Susana, "Recent Advances in Fiscal Response Models with an Application to Costa Rica," Journal of International Development, 12 (April 2000), 429-42.

Gupta, Sanjeev, Benedict Clements, Alexander Pivovasrky, and Erwin R. Tiongson, "Foreign Aid and Revenue Response: Does the Composition of Aid 
Matter?," Working Paper No. 03/176, International Monetary Fund (September 2003). Forthcoming, Review of Development Economics.

Hulten, Charles R., "Infrastructure Capital and Economic Growth: How Well you Use it may be more Important than how much you Have," Working Paper No. 5847, National Bureau of Economic Research (December 1996).

Larsen, Theo I., Huong Lan Pham, and Martin Rama, "Vietnam's Public Investment Program and its Impact on Poverty Reduction," unpublished, World Bank (April 2004).

Milanovic, Branko, "Is Inequality in Africa Really Different?" unpublished, World Bank (May 2003).

Nubukpo, Kako, "Dépenses publiques et croissance des économies de I'UEMOA," unpublished, University of Montpellier (December 2003).

Pattillo, Catherine, Hélène Poirson, and Luca Ricci, "What are the Channels through which External Debt Affects Growth?," Working Paper No. 04/15, International Monetary Fund (January 2004).

Ravallion, Martin, "Pro-Poor Growth: A Primer," Policy Research Working Paper No. 3242, World Bank (March 2004). 
Figure 1

Structure of the Model

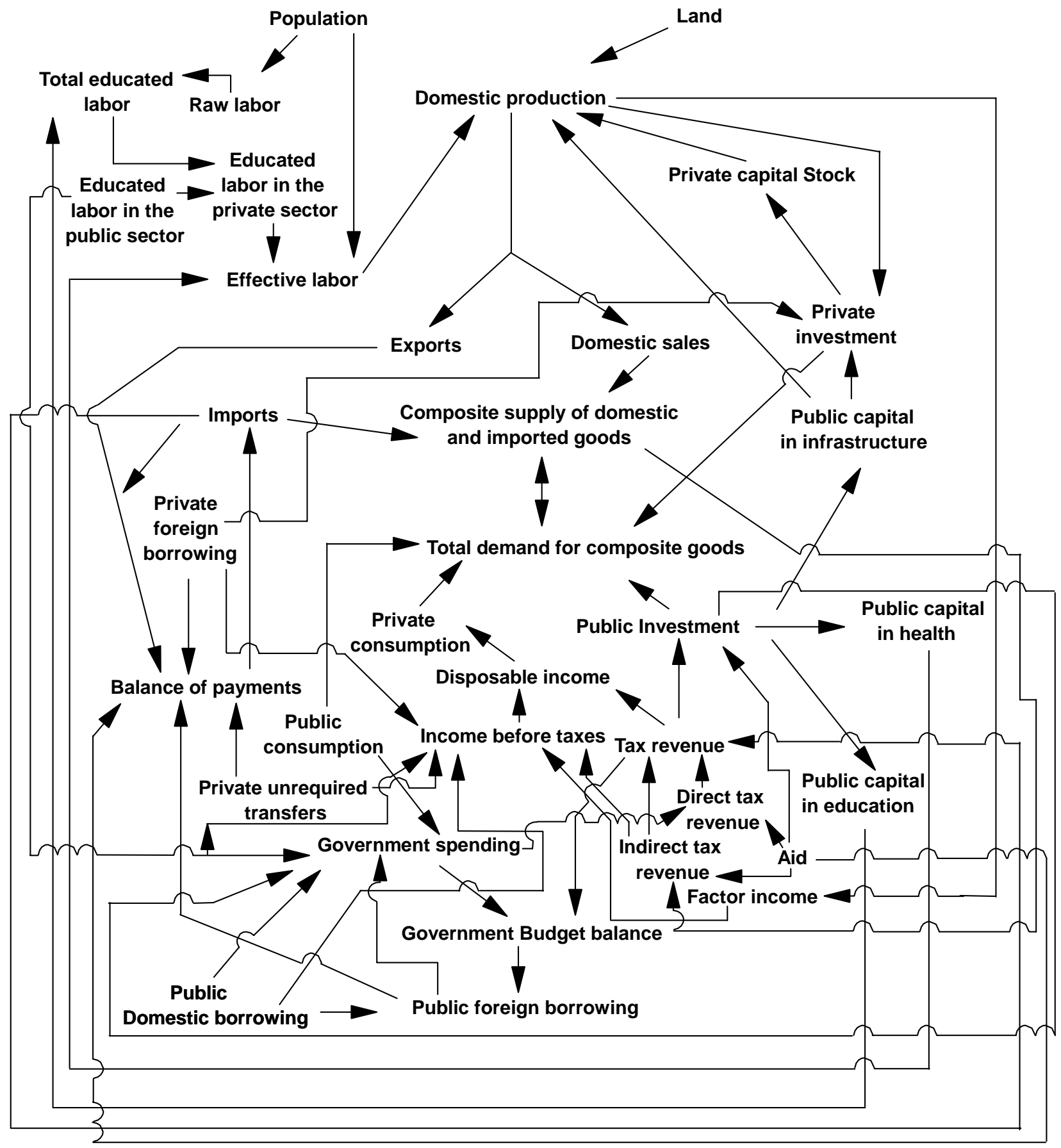


Figure 2

Niger: Real GDP Growth and ODA per capita, 1960-2002

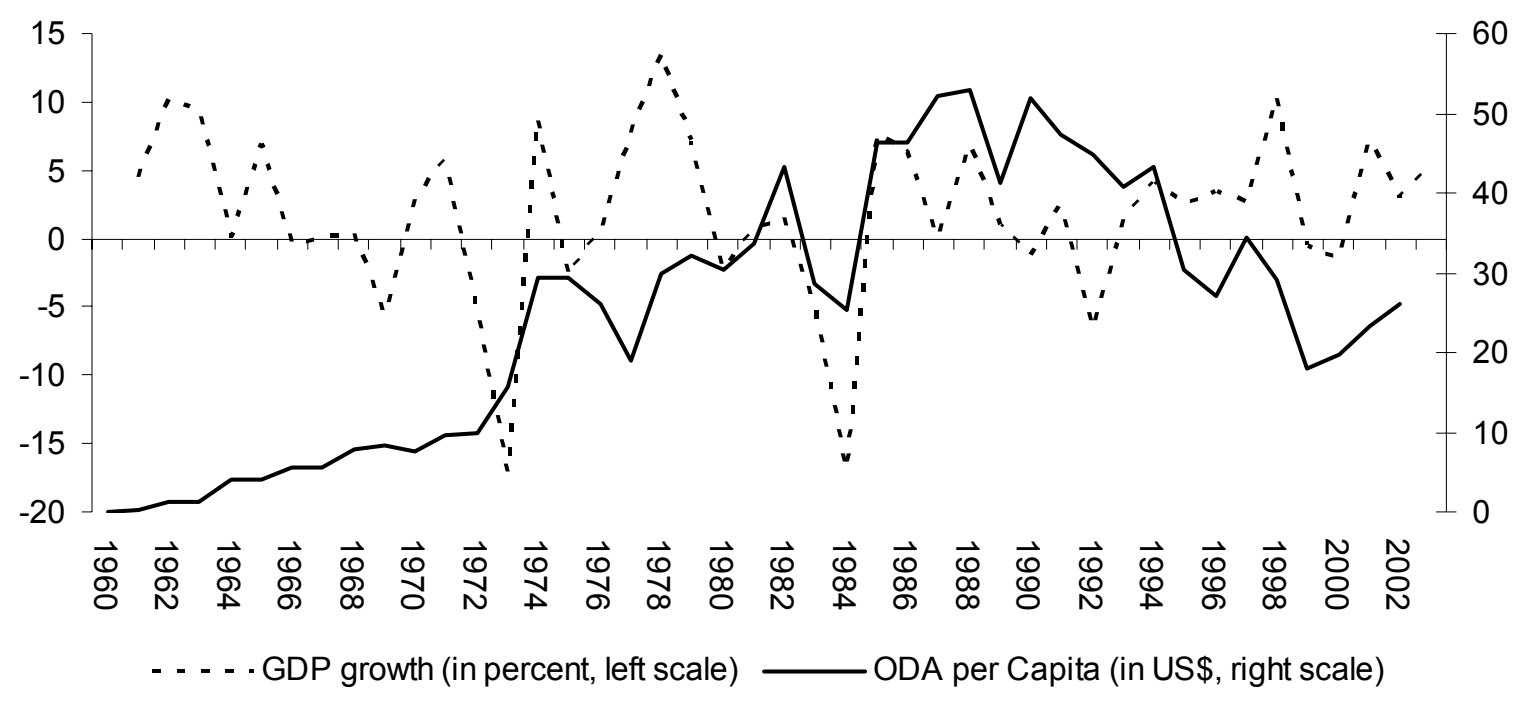

Source: OECD and World Bank. 
Figure 3

Niger: GDP per capita and Aid per capita, 1960-2002

(in current US dollars)

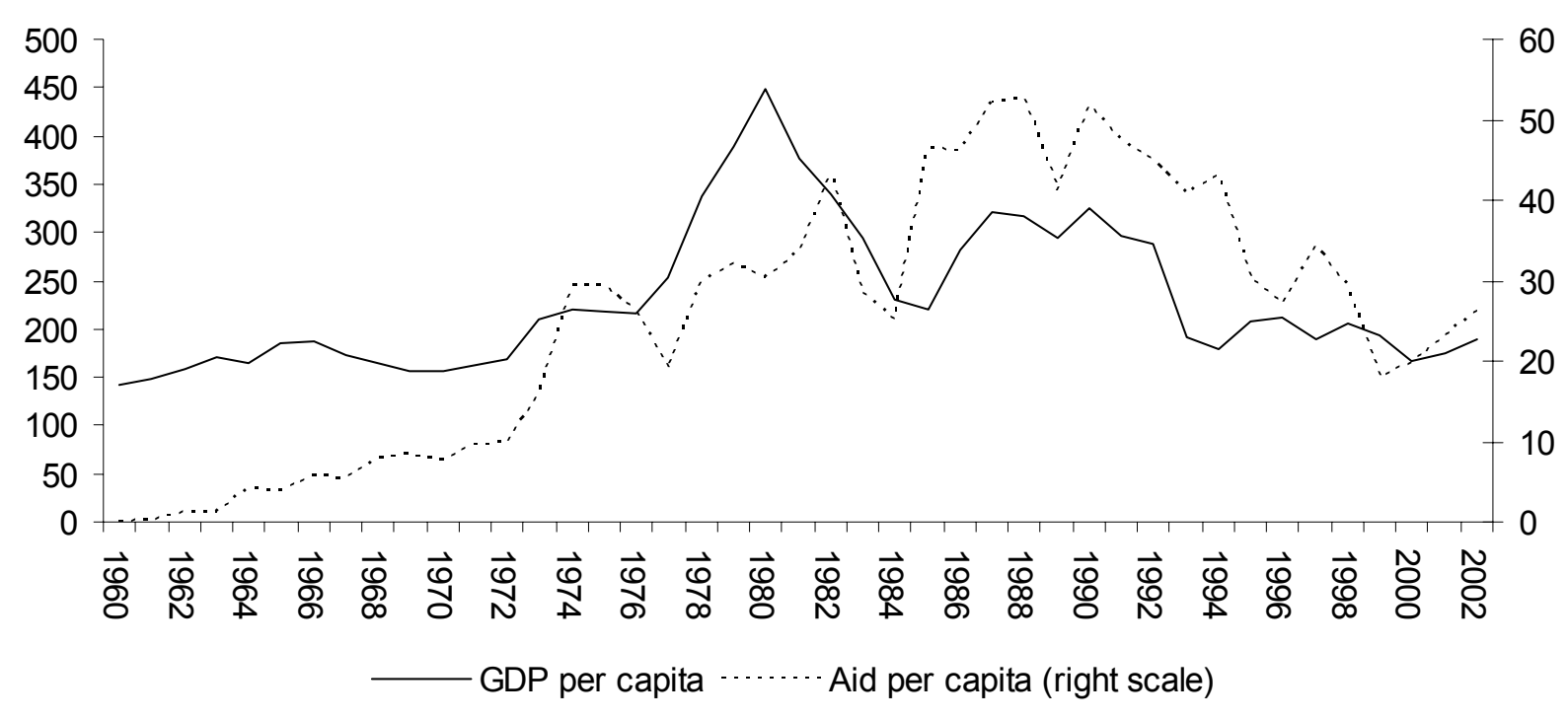

Note: Aid is defined as total net official development assistance. The series are taken from OECD.

Source: OECD and government authorities. 


\section{Figure 4}

\section{Niger: Composition of Aid per Capita (in US dollars)}

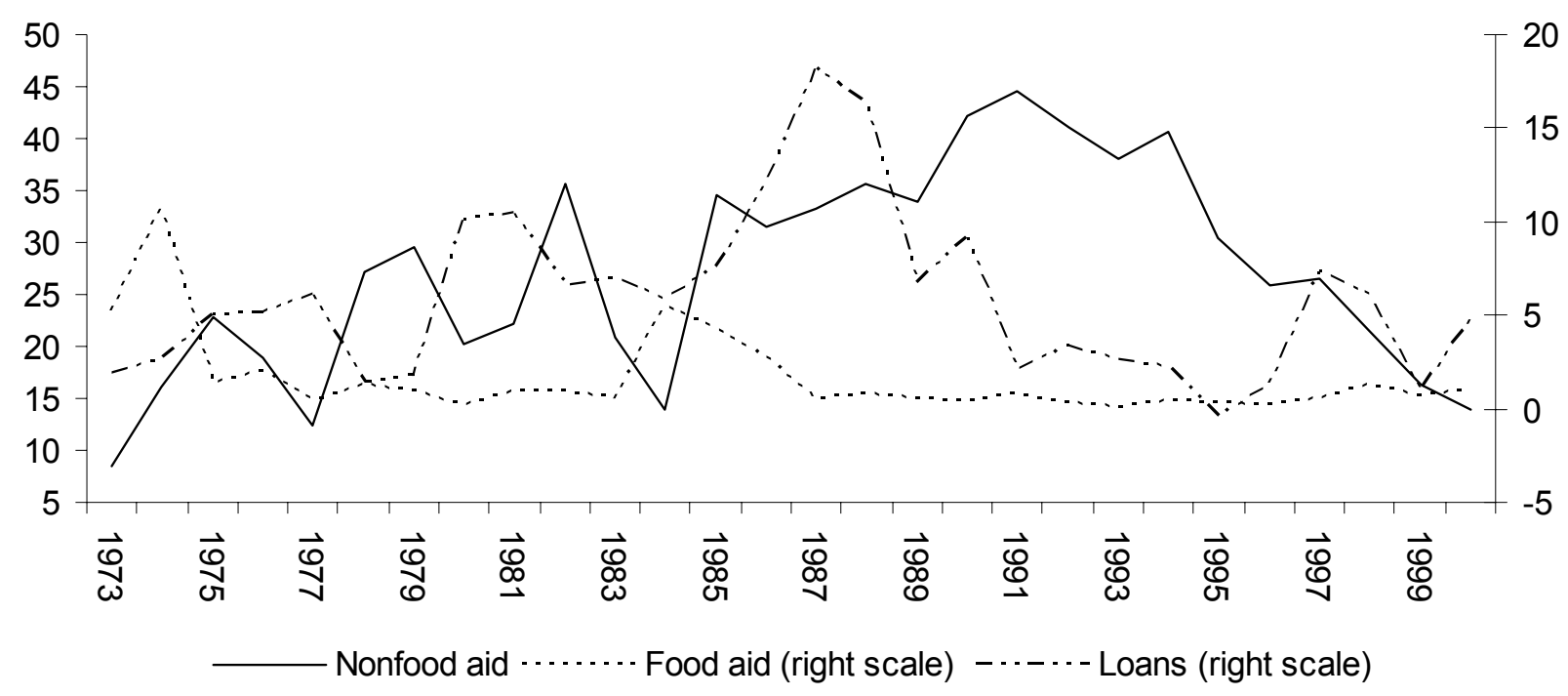

Note: Food aid is defined as the sum of food aid excluding relief food aid and relief food aid. Nonfood aid is the difference between official development asssistance (ODA) grants and food aid. Loans are total net ODA loans.

Source: OECD and government authorities. 
Figure 5

Niger: Aid and Fiscal Variables

(in percent)

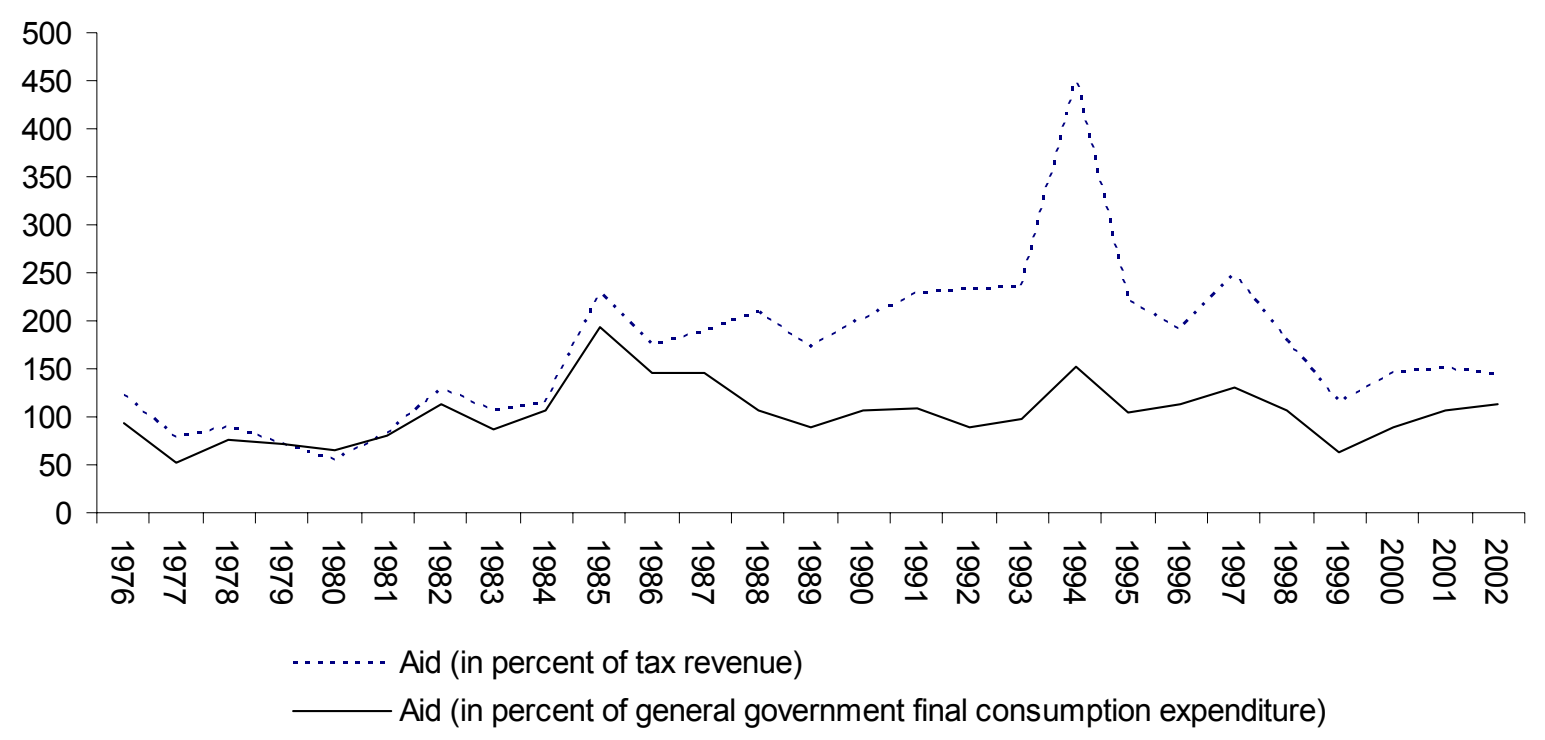

Note: Aid is defined as total net official development assistance. The series are taken from OECD and government authorities. Source: OECD and government authorities. 


\section{Figure 6}

\section{Niger: Public Investment and Aid (in percent of GDP)}

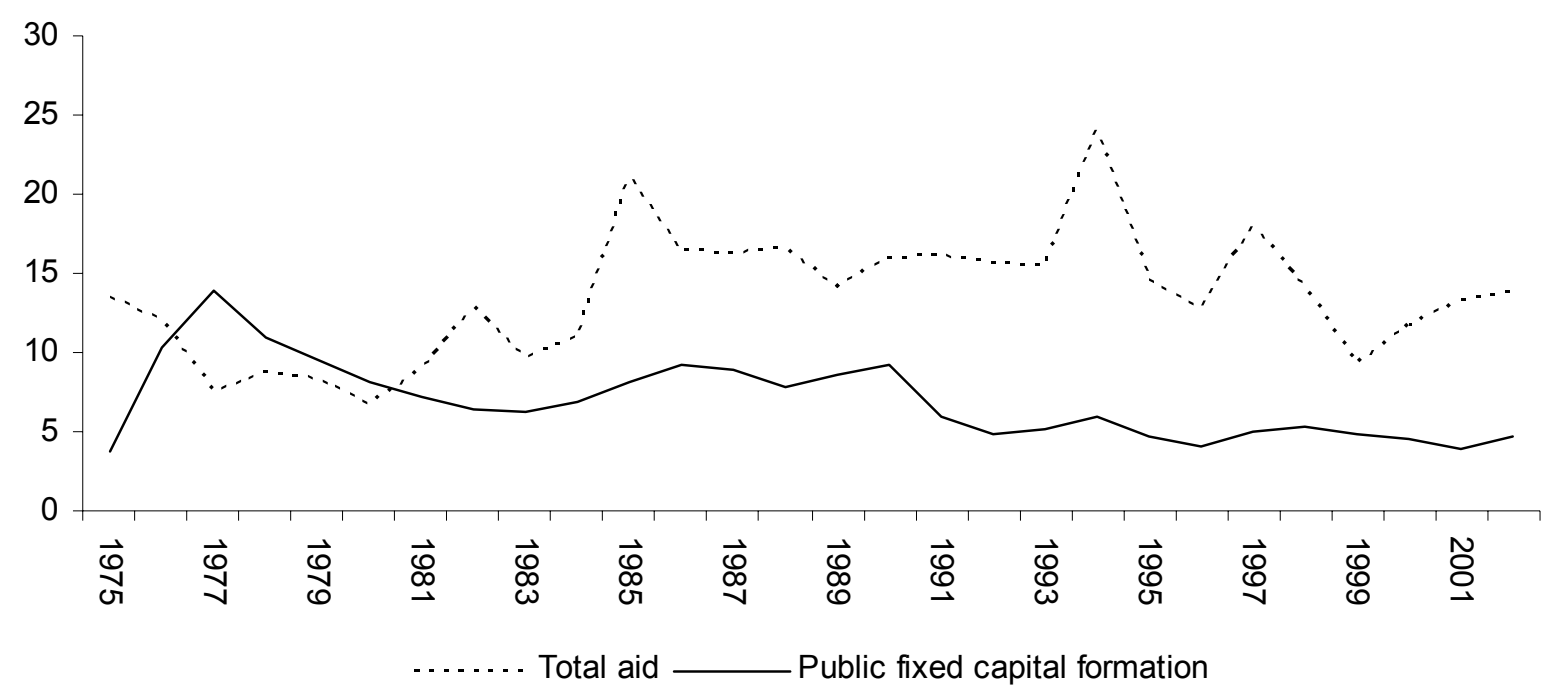

Note: Aid is defined as total net official development assistance.

Source: OECD and government authorities. 


\section{Figure 7}

\section{Niger: Public and Private Investment (in percent of GDP)}

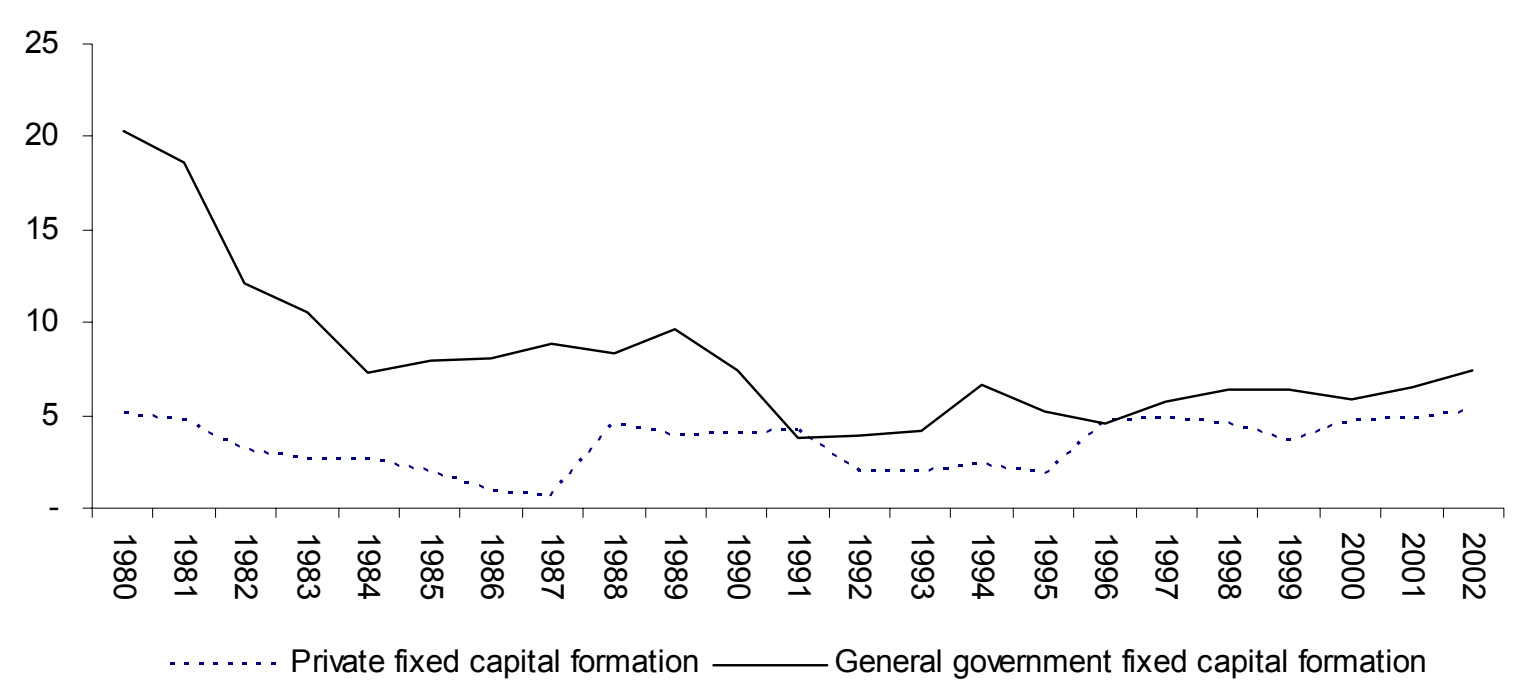

Source: World Bank African Database. 
Figure 8

Niger: Composition of Public Fixed Capital Formation

(in percent)

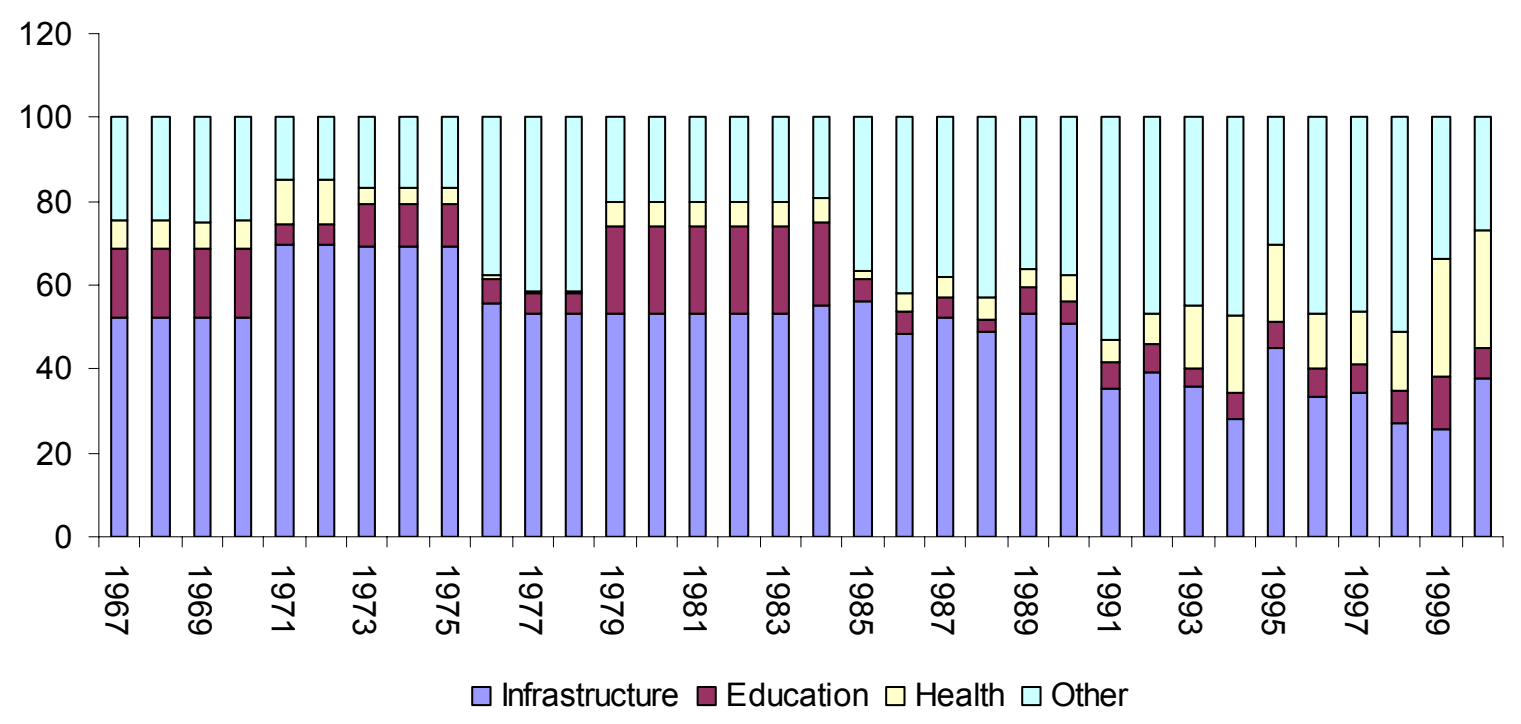

Note: The category "other" is defined as the sum of the following categories: agriculture, elevage, fauret et faune, micro real, devt tertiaire extra-adm, promotion humaine, etude et recherche.

Source: Government authorities. 
Figure 9

Niger: 5 Percent Increase in Aid to GDP Ratio, 2003-15

Poverty Reduction and Growth

(Percentage deviation from baseline)
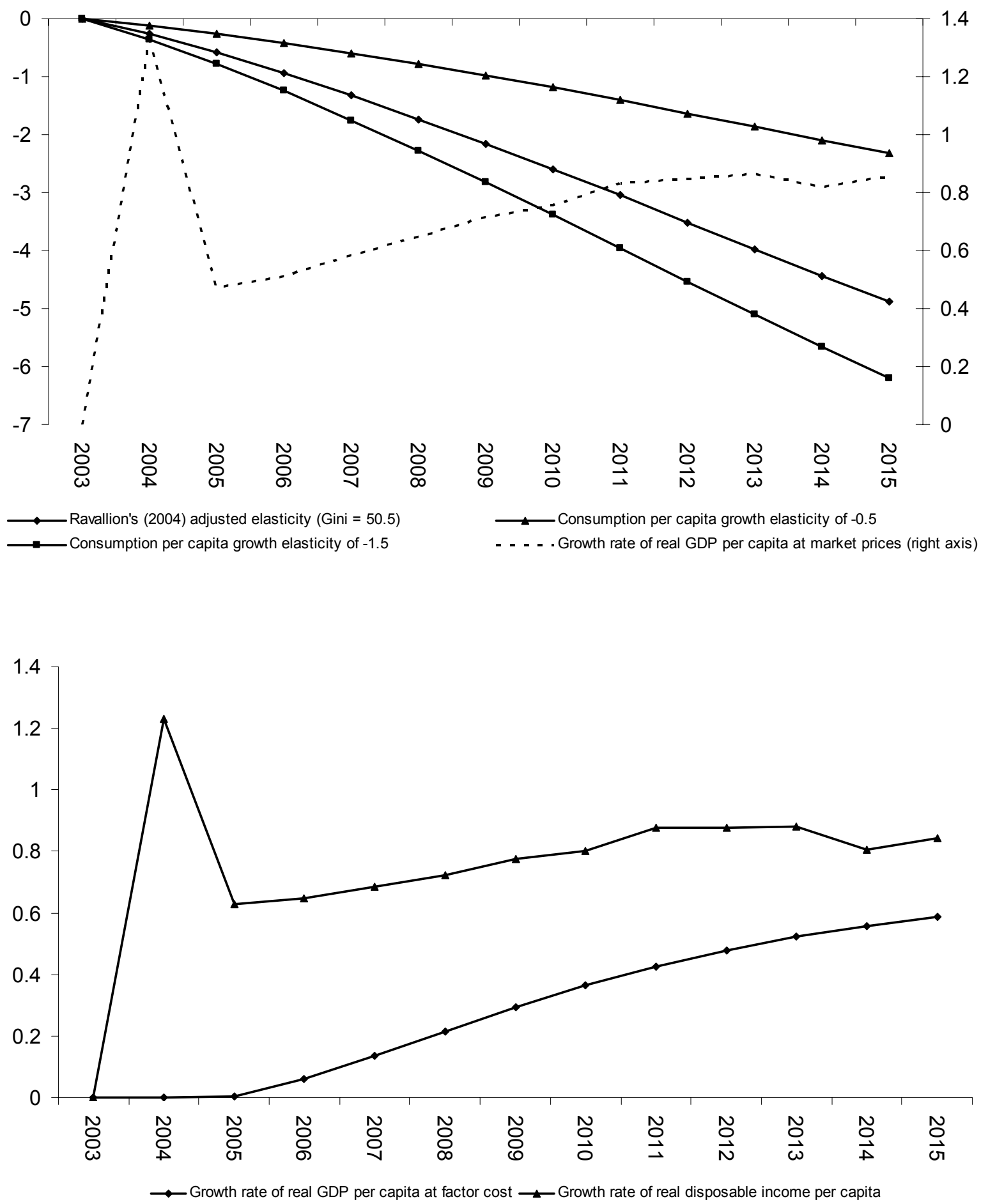
Figure 10

Niger: 20 \% Decrease in "Other" Investment in Percent of Total Public Investment Allocated to $20 \%$ Increase in Infrastructure Investment in Percent of Total Public Investment, 2003-15

Poverty Reduction and Growth (Percentage deviation from baseline)
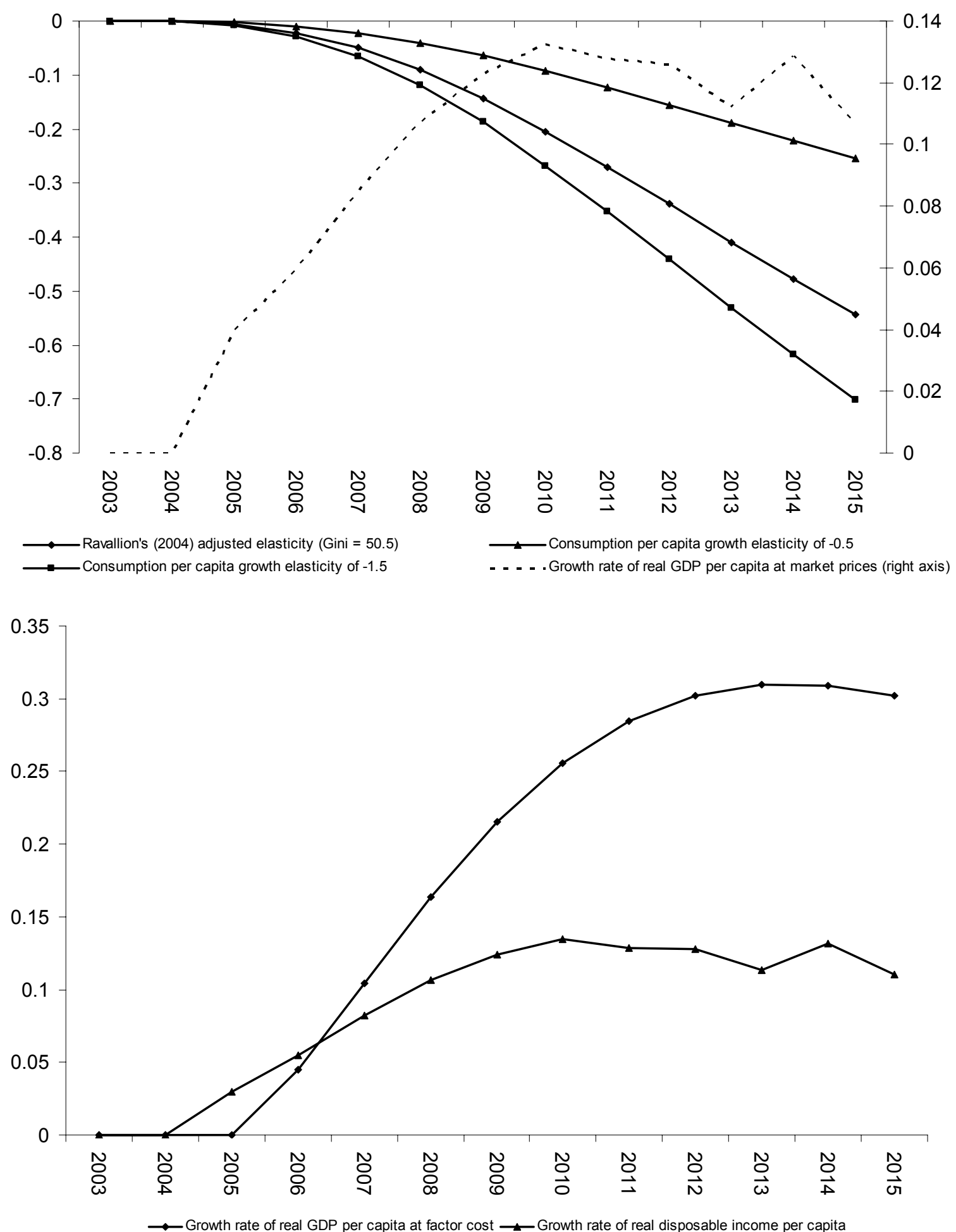
Figure 11

Niger: 10 Percent Decrease in Tariff Rate, No Change in Direct or Indirect Tax

Rate, 2003-15

Poverty Reduction and Growth

(Percentage deviation from baseline)

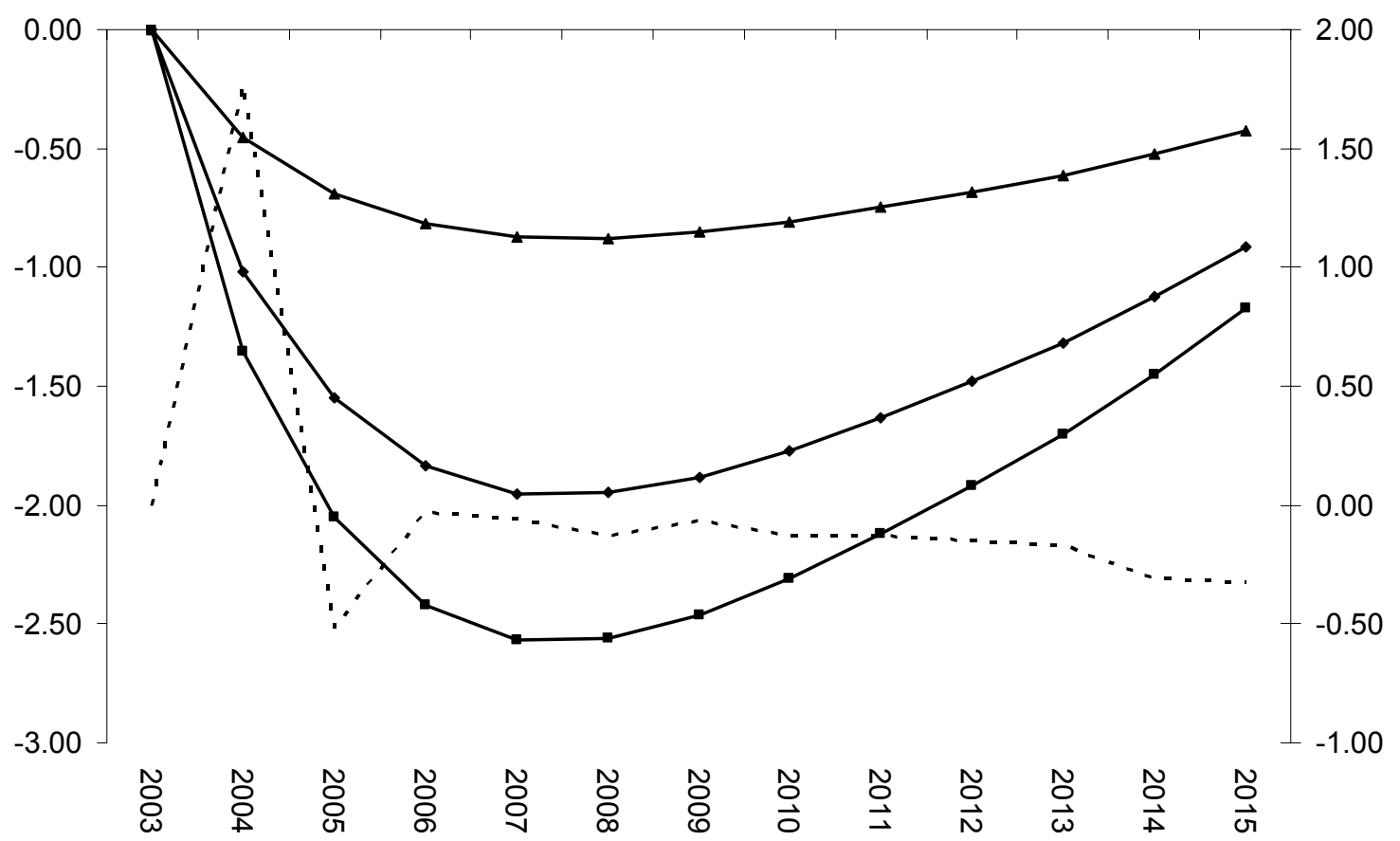

$\longrightarrow$ Ravallion's (2004) adjusted elasticity (Gini $=50.5)$

Consumption per capita growth elasticity of -0.5

$\longrightarrow$ Consumption per capita growth elasticity of -1.5

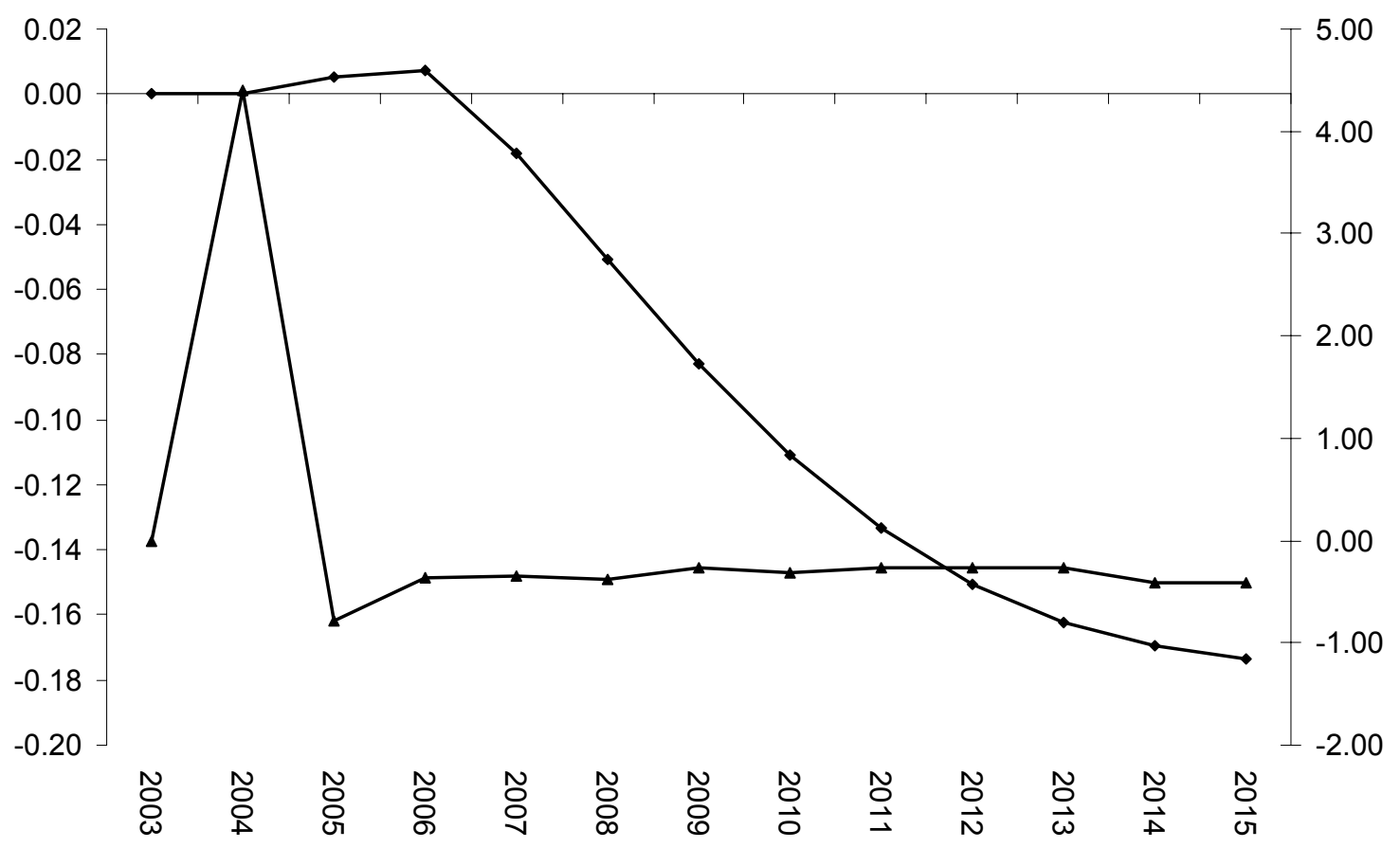

$\longrightarrow$ Growth rate of real GDP per capita at factor cost $\longrightarrow$ Growth rate of real disposable income per capita (right scale) 
Figure 12

Niger: 10 Percent Decrease in Tariff Rate, Increase in Direct Tax Rate to 5.2

Percent, 2003-15

Poverty Reduction and Growth

(Percentage deviation from baseline)
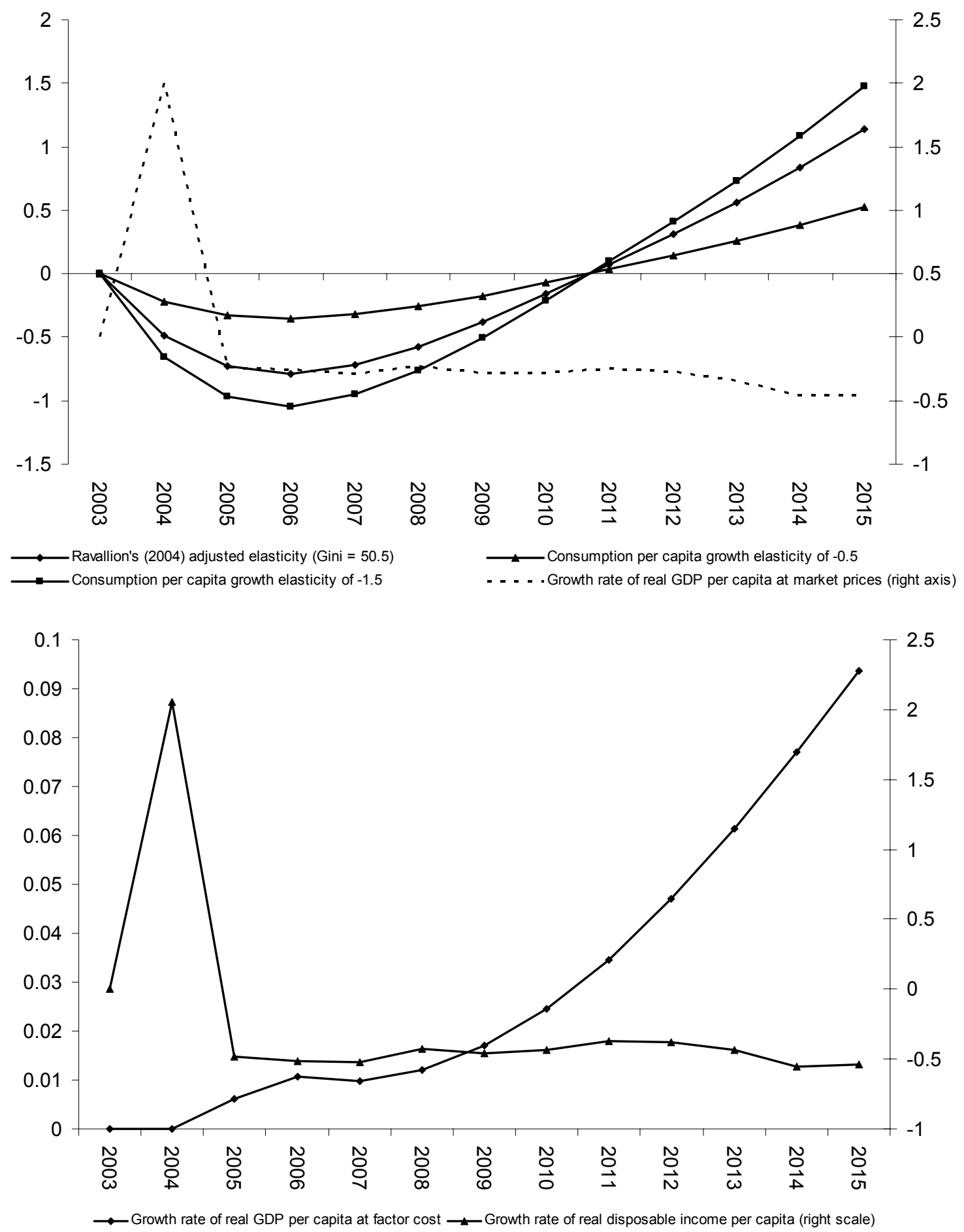
Figure 13

Niger: 10 Percent Decrease in Tariff Rate, Increase in Indirect Tax Rate to 4.4

Percent, 2003-15

Poverty Reduction and Growth

(Percentage deviation from baseline)
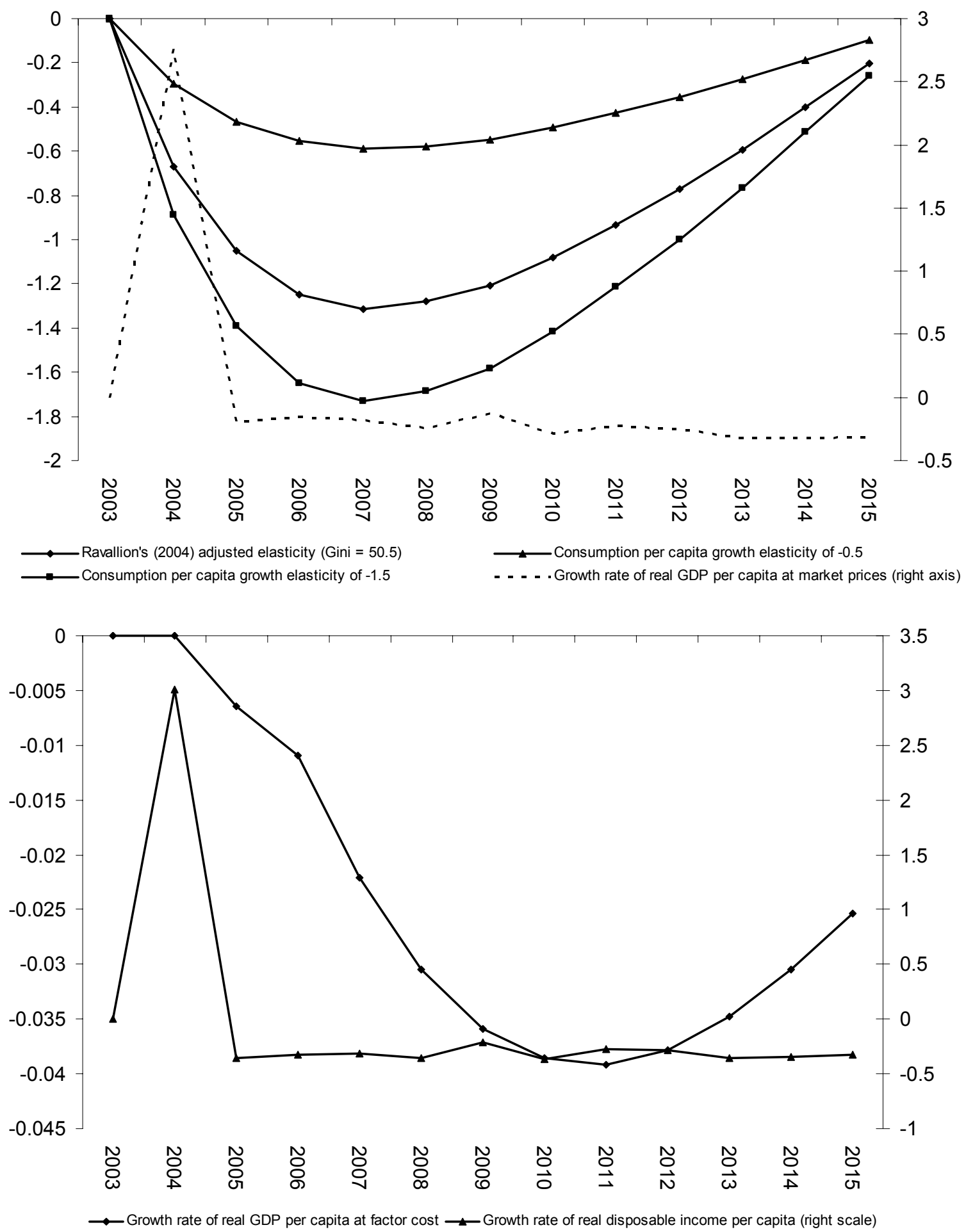
Table 1 : Social Development Indicators for Niger and Sub-Saharan Africa

\begin{tabular}{|c|c|c|c|c|c|c|c|c|}
\hline & \multicolumn{4}{|c|}{ Níger } & \multicolumn{4}{|c|}{ Average } \\
\hline & 1970 & 1980 & 1990 & 2002 & 1970 & 1980 & 1990 & 2002 \\
\hline $\begin{array}{l}\text { Infant mortality } \\
\text { rate (per } 1,000 \\
\text { live births) }\end{array}$ & 197.0 & 191.0 & 191.0 & 155.0 & 140.9 & 116.0 & 110.3 & 103.1 \\
\hline $\begin{array}{l}\text { Total fertility rate } \\
\text { (Births per } \\
\text { woman) }\end{array}$ & 8.0 & 8.0 & 7.6 & 7.1 & 6.6 & 6.6 & 6.1 & 5.1 \\
\hline $\begin{array}{l}\text { Population growth } \\
\text { (annual \%) }\end{array}$ & 2.8 & 3.1 & 3.2 & 3.0 & 2.7 & 3.1 & 2.9 & 2.2 \\
\hline $\begin{array}{l}\text { Life expectancy } \\
\text { at birth, total } \\
\text { (years) }\end{array}$ & 37.6 & 40.3 & 42.1 & 46.2 & 44.2 & 47.6 & 50.0 & 45.8 \\
\hline $\begin{array}{l}\text { Illiteracy rate, } \\
\text { adult total (\% of } \\
\text { people aged } 15 \\
\text { and above) }\end{array}$ & 94.3 & 92.1 & 88.6 & 82.9 & NA & NA & NA & 35.1 \\
\hline $\begin{array}{l}\text { Gross primary } \\
\text { enrollment ( } \% \\
\text { school age } \\
\text { population) }\end{array}$ & 13.3 & 25.3 & 28.8 & NA & 51.0 & 80.4 & 74.5 & $\mathrm{NA}$ \\
\hline $\begin{array}{l}\text { Improved water } \\
\text { source (\% of } \\
\text { population with } \\
\text { access) }\end{array}$ & NA & NA & 53 & NA & NA & NA & 53.1 & NA \\
\hline $\begin{array}{l}\text { Improved } \\
\text { sanitation } \\
\text { facilities (\% of } \\
\text { population with } \\
\text { access) }\end{array}$ & NA & NA & 15 & NA & NA & NA & 53.9 & $\mathrm{NA}$ \\
\hline
\end{tabular}

Source: World Bank 2004. World Development Indicators. 
Table 2: Niger and WAEMU: Government revenue (commitment basis, excluding grants, in percent of GDP), 1994-2002

\begin{tabular}{|l|l|l|l|l|l|l|l|l|l|}
\hline & 1994 & 1995 & 1996 & 1997 & 1998 & 1999 & 2000 & 2001 & 2002 \\
\hline Niger & $\mathbf{6 . 1}$ & $\mathbf{7 . 2}$ & $\mathbf{7 . 8}$ & $\mathbf{8 . 4}$ & $\mathbf{9 . 1}$ & $\mathbf{8 . 8}$ & $\mathbf{8 . 6}$ & $\mathbf{9 . 3}$ & $\mathbf{1 0 . 6}$ \\
\hline Benin & 12.7 & 14.8 & 15.1 & 14.5 & 15.3 & 16.0 & 16.6 & 16.2 & 17.1 \\
\hline Burkina Faso & 11.6 & 12.5 & 12.6 & 13.6 & 14.7 & 15.6 & 17.6 & 12.5 & 13.1 \\
\hline Côte d'Ivoire & 18.3 & 20.1 & 19.8 & 19.4 & 18.4 & 16.4 & 16.4 & 17.0 & 16.4 \\
\hline Guinea-Bissau & 12.3 & 12.7 & 12.4 & 15.3 & 5.4 & 17.8 & 19.2 & 19.6 & 13.8 \\
\hline Mali & 14.2 & 11.8 & 14.0 & 14.6 & 14.6 & 16.3 & 14.9 & 16.6 & 17.2 \\
\hline Senegal & 14.9 & 16.4 & 16.6 & 16.9 & 16.8 & 17.3 & 18.1 & 17.8 & 18.6 \\
\hline Togo & 12.1 & 14.7 & 14.7 & 14.7 & 15.3 & 14.4 & 13.3 & 13.8 & 12.4 \\
\hline WAEMU & $\mathbf{1 4 . 1}$ & $\mathbf{1 5 . 3}$ & $\mathbf{1 5 . 6}$ & $\mathbf{1 5 . 8}$ & $\mathbf{1 5 . 7}$ & $\mathbf{1 5 . 5}$ & $\mathbf{1 5 . 8}$ & $\mathbf{1 5 . 5}$ & $\mathbf{1 5 . 6}$ \\
\hline
\end{tabular}

Source: IMF, African Department Database. 
Table 3
Niger: Trend-based Projections, 2003-15

\begin{tabular}{|c|c|c|c|c|c|c|c|c|c|c|c|c|c|}
\hline & \multicolumn{13}{|c|}{ Years } \\
\hline & 2003 & 2004 & 2005 & 2006 & 2007 & 2008 & 2009 & 2010 & 2011 & 2012 & 2013 & 2014 & 2015 \\
\hline \multicolumn{14}{|l|}{$\begin{array}{l}\text { Real Sector (in billions of current CFA francs) } \\
\text { Tond con }\end{array}$} \\
\hline $\begin{array}{l}\text { Total supply of goods and services } \\
\text { Gross domestic product at factor cost }\end{array}$ & $\begin{array}{l}2011.8 \\
1523.1\end{array}$ & $\begin{array}{l}2014.3 \\
1564.8\end{array}$ & $\begin{array}{l}21444.0 \\
1625.1\end{array}$ & $\begin{array}{l}2223.5 \\
1700.2\end{array}$ & $\begin{array}{l}2313.5 \\
1783.6\end{array}$ & $\begin{array}{l}2409.6 \\
1872.7\end{array}$ & $\begin{array}{l}2510.3 \\
1965.4\end{array}$ & $\begin{array}{l}2614.3 \\
2060.0\end{array}$ & $\begin{array}{l}21193.4 \\
2153.4\end{array}$ & $\begin{array}{l}2826.5 \\
2247.2\end{array}$ & $\begin{array}{l}2344.9 \\
2340.8\end{array}$ & $\begin{array}{l}3440.1 \\
2440.1\end{array}$ & $\begin{array}{l}3163.6 \\
2538.7\end{array}$ \\
\hline Imports of goods and NFS (inclusive of tariffs) & 488.7 & 509.5 & 518.9 & 523.3 & 529.9 & 536.8 & 544.8 & 554.3 & 566.0 & 579.3 & 594.1 & 608.7 & 624.9 \\
\hline 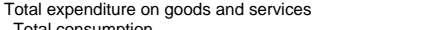 & $\begin{array}{l}2011.8 \\
\end{array}$ & 2074.3 & $\begin{array}{l}2143.9 \\
17218\end{array}$ & 2223.3 & 2313.3 & 2409.5 & 2510.2 & 2614.3 & 2719.4 & 2826.4 & 2934.9 & 3048.8 & 3163.8 \\
\hline $\begin{array}{l}\text { Total consumpition } \\
\text { Private consumption }\end{array}$ & $\begin{array}{l}1598.3 \\
1367.2\end{array}$ & $\begin{array}{l}1660.5 \\
1406.7\end{array}$ & $\begin{array}{l}17211.8 \\
1458.4\end{array}$ & $\begin{array}{l}1795.6 \\
1520.5\end{array}$ & $\begin{array}{l}1877.2 \\
1589.2\end{array}$ & 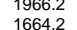 & $\begin{array}{l}2060.9 \\
1744.4\end{array}$ & $\begin{array}{l}2159.6 \\
1828.2\end{array}$ & $\begin{array}{l}2259.5 \\
1913.3\end{array}$ & $\begin{array}{l}2361.0 \\
2000.0\end{array}$ & $\begin{array}{l}2463.4 \\
2087.6\end{array}$ & $\begin{array}{l}2570.8 \\
2179.2\end{array}$ & 2678.7 \\
\hline Public spending on goods and services & 231.1 & 253.9 & $\begin{array}{l}1450.4 \\
263.4\end{array}$ & 2751 & $\begin{array}{l}1589.2 \\
288.1\end{array}$ & 3020 & $\begin{array}{r}11444.4 \\
316.5\end{array}$ & $\begin{array}{r}1828.2 \\
331.4\end{array}$ & $\begin{array}{r}1913.3 \\
346.1\end{array}$ & $\begin{array}{r}2000.0 \\
361.0\end{array}$ & 375.8 & $\begin{array}{l}2179.2 \\
3916\end{array}$ & $\begin{array}{r}2211.5 \\
407.2\end{array}$ \\
\hline Total investment & 159.0 & 149.7 & 148.4 & 144.8 & 144.6 & 143.7 & 141.8 & $\begin{array}{l}139.4 \\
1394\end{array}$ & $\begin{array}{l}136.6 \\
136.6\end{array}$ & $\begin{array}{l}133.6 \\
0\end{array}$ & $\begin{array}{l}130.2 \\
130.2\end{array}$ & $\begin{array}{l}126.7 \\
126.7\end{array}$ & $\begin{array}{l}422.7 \\
122.7\end{array}$ \\
\hline Private investment & 88.8 & 87.2 & 91.6 & 91.6 & 95.6 & 98.9 & 101.4 & 103.5 & 105.0 & 106.2 & 107.0 & 107.6 & 108.0 \\
\hline $\begin{array}{l}\text { Public investment } \\
\text { Exports of goods and NFS }\end{array}$ & $\begin{array}{r}70.2 \\
25.5\end{array}$ & $\begin{array}{r}62.5 \\
264.0\end{array}$ & $\begin{array}{r}56.7 \\
273.8\end{array}$ & $\begin{array}{r}53.3 \\
282.9\end{array}$ & $\begin{array}{r}49.0 \\
291.5\end{array}$ & $\begin{array}{r}44.8 \\
299.7\end{array}$ & $\begin{array}{r}40.4 \\
307.5\end{array}$ & $\begin{array}{r}36.0 \\
315.2\end{array}$ & $\begin{array}{r}31.6 \\
323.3\end{array}$ & $\begin{array}{r}27.4 \\
331.9\end{array}$ & $\begin{array}{r}23.2 \\
341.3\end{array}$ & $\begin{array}{r}19.1 \\
351.3\end{array}$ & $\begin{array}{r}14.8 \\
362.3\end{array}$ \\
\hline Gross domestic product at market prices & 1587.5 & 1711.1 & 1775.3 & 1853.9 & 1941.8 & 2035.6 & 2133.5 & 2233.6 & 2333.0 & 2433.1 & 2533.3 & 2639.1 & 2744.6 \\
\hline Disposable income & 1546.5 & 1591.6 & 1655.6 & 1734.3 & 1821.3 & 1914.1 & 2010.5 & 2108.9 & 2206.1 & 2303.7 & 2401.3 & 2504.6 & 2607.3 \\
\hline \multicolumn{14}{|l|}{ Poverty rate } \\
\hline 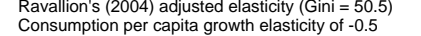 & 63.0 63.0 & $\begin{array}{l}63.0 \\
63.0\end{array}$ & $\begin{array}{l}62.8 \\
62.9\end{array}$ & $\begin{array}{l}62.5 \\
62.8\end{array}$ & $\begin{array}{l}02.0 \\
62.6\end{array}$ & $\begin{array}{l}61.4 \\
62.3\end{array}$ & 60.7 & $\begin{array}{l}60.1 \\
61.7\end{array}$ & $\begin{array}{l}59.4 \\
61.4\end{array}$ & $\begin{array}{l}58.8 \\
61.1\end{array}$ & 60.8 & $\begin{array}{l}5.7 \\
60.6\end{array}$ & 56.2 \\
\hline Consumption per capita growth elasticity of -1.0 & 63.0 & 63.0 & $\begin{array}{l}62.9 \\
62.8\end{array}$ & 62.5 & 62.1 & 61.6 & 61.0 & 60.4 & $\begin{array}{ll}51.4 \\
59.8\end{array}$ & 59.3 & 58.7 & 58.3 & 57.8 \\
\hline Consumption per capita growth elasticity of -1.5 & 63.0 & 62.9 & 62.7 & 62.3 & 61.7 & 60.9 & 60.0 & 59.1 & 58.3 & 57.5 & 56.7 & 56.0 & 55.4 \\
\hline \multicolumn{14}{|l|}{ External Sector (\% of GDP) } \\
\hline $\begin{array}{l}\text { Current account } \\
\text { Trade balance }\end{array}$ & $\begin{array}{l}-6.2 \\
-9.4\end{array}$ & $\begin{array}{l}-5.5 \\
-92\end{array}$ & $\begin{array}{l}-4.8 \\
-8.7\end{array}$ & $\begin{array}{l}-3.9 \\
-8 .\end{array}$ & $\begin{array}{l}-3.0 \\
-7.6\end{array}$ & $\begin{array}{l}-2.3 \\
-71\end{array}$ & $\begin{array}{l}-1.7 \\
-6.7\end{array}$ & $\begin{array}{l}-1.1 \\
-6.4\end{array}$ & $\begin{array}{l}-0.7 \\
-62\end{array}$ & $\begin{array}{l}-0.3 \\
-60\end{array}$ & $\begin{array}{r}0.0 \\
-5.9\end{array}-10$ & $\begin{array}{l}0.3 \\
-58\end{array}$ & 0.6 \\
\hline Exports of goods and NFS & $\begin{array}{l}-9.4 \\
16.0\end{array}$ & 15.4 & $\begin{array}{l}-0.1 \\
15.4\end{array}$ & $\begin{array}{l}-0.1 \\
15.3\end{array}$ & $\begin{array}{l}-1.00 \\
15.0\end{array}$ & 14.7 & 14.4 & 14.1 & $\begin{array}{l}-0.2 \\
13.9\end{array}$ & $\begin{array}{l}-0.0 \\
13.6\end{array}$ & $\begin{array}{l}-5.9 \\
13.5\end{array}$ & $\begin{array}{lll}-1.0 \\
13.3\end{array}$ & $\begin{array}{l}-5.6 \\
13.2\end{array}$ \\
\hline Imports of goods and NFS & $\begin{array}{l}25.5 \\
25.5\end{array}$ & $\begin{array}{l}24.6 \\
24.6\end{array}$ & 22.4 & $\begin{array}{l}23.3 \\
23.3\end{array}$ & $\begin{array}{l}22.6 \\
22.6\end{array}$ & 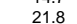 & $\begin{array}{l}21.1 \\
21.4\end{array}$ & 20.5 & 20.1 & $\begin{array}{l}19.7 \\
19.7\end{array}$ & $\begin{array}{l}19.4 \\
19.4\end{array}$ & $\begin{array}{l}10.1 \\
19.1\end{array}$ & $\begin{array}{l}13.2 \\
18.8\end{array}$ \\
\hline Private unrequited transfers & 0.7 & 0.7 & 0.7 & 0.7 & 0.7 & 0.7 & 0.7 & 0.6 & 0.6 & 0.6 & $\begin{array}{r}0.4 \\
0.6\end{array}$ & 0.6 & 0.6 \\
\hline Income (net) & -0.5 & -0.5 & -0.5 & -0.5 & -0.5 & -0.6 & -0.6 & -0.6 & -0.6 & -0.6 & -0.6 & -0.6 & -0.6 \\
\hline $\begin{array}{l}\text { Public } \\
\text { Private }\end{array}$ & $\begin{array}{c}-1.0 \\
0.5\end{array}$ & -1.0 & $\begin{array}{c}-1.0 \\
0.5\end{array}$ & $\begin{array}{c}-1.0 \\
0.5\end{array}$ & $\begin{array}{r}-1.0 \\
0.4\end{array}$ & $\begin{array}{l}-1.0 \\
0.4\end{array}$ & $\begin{array}{r}-1.0 \\
0.4\end{array}$ & $\begin{array}{r}-1.0 \\
0.4\end{array}$ & -1.0 & -0.9 & -0.9 & -0.9 & -0.9 \\
\hline $\begin{array}{l}\text { Pirvate } \\
\text { Aid, total }\end{array}$ & $\begin{array}{r}0.5 \\
10.7\end{array}$ & $\begin{array}{r}0.5 \\
10.7\end{array}$ & $\begin{array}{l}0.5 \\
10.7\end{array}$ & $\begin{array}{r}0.5 \\
10.7\end{array}$ & $\begin{array}{l}0.4 \\
10.7\end{array}$ & $\begin{array}{l}0.4 \\
10.7\end{array}$ & $\begin{array}{c}0.4 \\
10.7\end{array}$ & $\begin{array}{l}0.4 \\
10.7\end{array}$ & $\begin{array}{l}0.4 \\
10.7\end{array}$ & $\begin{array}{l}0.4 \\
10.7\end{array}$ & $\begin{array}{r}0.4 \\
10.7\end{array}$ & $\begin{array}{l}0.4 \\
10.7\end{array}$ & $\begin{array}{r}0.3 \\
10.7\end{array}$ \\
\hline $\begin{array}{l}\text { Ala, toral } \\
\text { Other current account flows (net) }\end{array}$ & $\begin{array}{c}-7.7 \\
-7.7\end{array}$ & $\begin{array}{ll}-7.1 \\
-7.1\end{array}$ & $\begin{array}{l}10.7 \\
-6.9\end{array}$ & -6.6 & -6.3 & $\begin{array}{l}10.0 \\
-6.0\end{array}$ & -5.7 & -5.5 & $\begin{array}{l}10.7 \\
-5.2\end{array}$ & -50 & -4.8 & -4.6 & $\begin{array}{l}10.7 \\
-4.5\end{array}$ \\
\hline Capital account & 3.7 & 2.7 & 2.6 & 2.6 & 2.5 & 2.4 & 2.4 & 2.3 & 2.2 & 2.1 & 2.0 & 1.9 & 1.8 \\
\hline $\begin{array}{l}\text { Private borrowing } \\
\text { Public borrowing }\end{array}$ & 0.2 & 0.2 & 0.2 & 0.2 & 0.2 & 0.2 & 0.2 & 0.2 & 0.2 & 0.2 & 0.2 & 0.2 & 0.2 \\
\hline $\begin{array}{l}\text { Public borrowing } \\
\text { Errors and omissions }\end{array}$ & $\begin{array}{l}3.5 \\
0.0\end{array}$ & 0.0 & $\begin{array}{l}2.3 \\
0.0\end{array}$ & $\begin{array}{l}2.3 \\
0.0\end{array}$ & $\begin{array}{l}2.2 \\
0.0\end{array}$ & $\begin{array}{l}2.2 \\
0.0\end{array}$ & $\begin{array}{l}2.1 \\
0.0\end{array}$ & $\begin{array}{l}2.0 \\
0.0\end{array}$ & $\begin{array}{l}1.9 \\
0.0\end{array}$ & $\begin{array}{l}1.8 \\
0.0\end{array}$ & $\begin{array}{l}1.7 \\
0.0\end{array}$ & $\begin{array}{l}1.7 \\
0.0\end{array}$ & $\begin{array}{l}1.6 \\
0.0\end{array}$ \\
\hline \\
\hline Total revenue (including grants) & 20.5 & 19.9 & 19.6 & 19.2 & 18.9 & 18.6 & & 18.0 & 17.8 & & 17.5 & 17.4 & \\
\hline Domestic taxes & 4.5 & 4.1 & 3.8 & 3.6 & 3.5 & 3.3 & 3.2 & 3.1 & 3.0 & 2.9 & 2.8 & 2.7 & 2.7 \\
\hline Direct taxes & 2.4 & 2.2 & 2.0 & 1.9 & 1.8 & 1.6 & 1.5 & 1.5 & 1.4 & 1.3 & 1.2 & 1.1 & 1.1 \\
\hline $\begin{array}{l}\text { Indirect taxes } \\
\text { nngts }\end{array}$ & 2.1 & 1.9 & 1.8 & 1.8 & 1.7 & 1.7 & 1.6 & 1.6 & 1.6 & 1.6 & 1.6 & 1.6 & 1.6 \\
\hline $\begin{array}{l}\text { Indirect taxes on imports } \\
\text { Foreign aid (grants) }\end{array}$ & 5.3 & $\begin{array}{r}5.2 \\
107\end{array}$ & $\begin{array}{l}5.1 \\
107\end{array}$ & $\begin{array}{r}4.9 \\
107\end{array}$ & $\begin{array}{r}4.7 \\
107\end{array}$ & $\begin{array}{c}4.6 \\
107\end{array}$ & $\begin{array}{r}4.4 \\
107\end{array}$ & $\begin{array}{r}4.3 \\
107\end{array}$ & $\begin{array}{r}4.2 \\
107\end{array}$ & 4.1 & 4.1 & $\begin{array}{r}4.0 \\
107\end{array}$ & 3.9 \\
\hline $\begin{array}{l}\text { Forelgn ald grants) } \\
\text { Total expenditure }\end{array}$ & 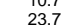 & $\begin{array}{l}23.0 \\
23.0\end{array}$ & $\frac{10.1}{25}$ & $\begin{array}{l}10.6 \\
222.2\end{array}-2$ & $\begin{array}{l}10.8 \\
218\end{array}$ & 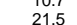 & 2011 & 20.8 & 20.5 & $\begin{array}{ll}20.1 \\
203\end{array}$ & 20.0 & 10.8 & 19.6 \\
\hline Spending on goods and services & 14.6 & 14.8 & 14.8 & 14.8 & 14.8 & 14.8 & 14.8 & 14.8 & $\begin{array}{ll}20.8 \\
14.8\end{array}$ & $\begin{array}{ll}20.8 \\
14.8\end{array}$ & 14.8 & 14.8 & $\begin{array}{l}19.6 \\
14.8\end{array}$ \\
\hline Wages and salaries & 3.6 & 3.4 & 3.4 & 3.4 & 3.4 & 3.3 & 3.3 & 3.3 & 3.3 & 3.2 & 3.2 & 3.2 & 3.2 \\
\hline Investment & 4.4 & 3.7 & 3.2 & 2.9 & 2.5 & 2.2 & 1.9 & 1.6 & 1.4 & 1.1 & 0.9 & 0.7 & 0.5 \\
\hline $\begin{array}{l}\text { Interest payments } \\
\text { Domestit debt }\end{array}$ & 1.1 & 1.1 & 1.1 & 1.1 & 1.1 & 1.1 & 1.1 & 1.1 & 1.1 & 1.1 & 1.1 & 1.1 & 1.1 \\
\hline $\begin{array}{l}\text { Domestic debt } \\
\text { Foreign debt }\end{array}$ & $\begin{array}{l}0.1 \\
10\end{array}$ & $\begin{array}{l}0.1 \\
10\end{array}$ & $\begin{array}{l}0.1 \\
10\end{array}$ & $\begin{array}{l}0.1 \\
10\end{array}$ & $\begin{array}{l}0.1 \\
10\end{array}$ & $\begin{array}{l}0.1 \\
10\end{array}$ & $\begin{array}{l}0.1 \\
10\end{array}$ & $\begin{array}{l}0.1 \\
1.0\end{array}$ & $\begin{array}{l}0.1 \\
10\end{array}$ & $\begin{array}{l}0.1 \\
0.9\end{array}$ & $\begin{array}{l}0.1 \\
0.9\end{array}$ & 0.9 & 0.1 \\
\hline Overall fiscal balance including grants (cash basis) & -3.5 & -3.4 & -3.3 & -3.3 & -32 & -3.0 & -3.1 & -30 & -2.0 & -28 & -2.7 & -27 & $\begin{array}{c}0.9 \\
-26\end{array}$ \\
\hline Total financing & 3.5 & 3.4 & 3.3 & 3.3 & 3.2 & 3.2 & 3.1 & 3.0 & 2.9 & 2.8 & 2.7 & 2.7 & 2.6 \\
\hline Foreign financing & 3.5 & 2.4 & 2.3 & 2.3 & 2.2 & 2.2 & 2.1 & 2.0 & 1.9 & 1.8 & 1.7 & 1.7 & 1.6 \\
\hline Domestic borrowing & 0.0 & 1.0 & 1.0 & 1.0 & 1.0 & 1.0 & 1.0 & 1.0 & 1.0 & 1.0 & 1.0 & 1.0 & 1.0 \\
\hline \multicolumn{14}{|l|}{ 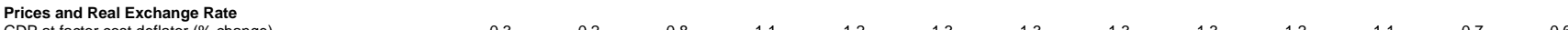 } \\
\hline xes, $\%$ change) & $\begin{array}{l}-0.3 \\
-1.8\end{array}$ & $\begin{array}{l}-0.2 \\
-0.4\end{array}$ & 0.3 & $\begin{array}{l}-1.1 \\
0.6\end{array}$ & $\begin{array}{r}-1.2 \\
0.7\end{array}$ & 0.7 & 0.7 & $\begin{array}{r}-1.3 \\
0.6\end{array}$ & $\begin{array}{r}-1.3 \\
0.5\end{array}$ & $\begin{array}{l}-1.22 \\
0.5\end{array}$ & $\begin{array}{l}-1.1 \\
04\end{array}$ & $\begin{array}{llll}-0.1 & -1\end{array}$ & $\begin{array}{l}-0.6 \\
0.3\end{array}$ \\
\hline $\begin{array}{l}\text { Composite good price (after indiri } \\
\text { Real exchange rate (\% change) }\end{array}$ & 9.9 & 0.4 & -0.3 & -0.6 & -0.7 & -0.7 & -0.7 & -0.6 & -0.5 & -0.5 & -0.4 & -0.4 & -0.3 \\
\hline \multirow{2}{*}{\multicolumn{14}{|c|}{ Mem }} \\
\hline Real GDP per capita at facto & 2.2 & -0.1 & & & 3.1 & 3.3 & 3.3 & 3.1 & 2.8 & 2.5 & 2.2 & 1.9 & 1.5 \\
\hline Real GDP per capita at market prices (\% change) & 3.6 & 5.1 & 0.4 & 0.7 & 1.0 & 1.0 & 1.0 & 0.9 & 0.8 & 0.7 & 0.7 & 0.7 & 0.6 \\
\hline Real disposable & 3.5 & 0.2 & 0.7 & 1.0 & 1.3 & 1.3 & 1.2 & 1.1 & 1.0 & 0.9 & 0.8 & 0.8 & 0.7 \\
\hline nita (\% chance) & 9.7 & 9.3 & 9.3 & $\begin{array}{l}9.4 \\
0.5\end{array}$ & 9.4 & 9.4 & 9.4 & 9.4 & 9.5 & 9.5 & 9.5 & $\begin{array}{l}9.5 \\
0.8\end{array}$ & 9.5 \\
\hline $\begin{array}{l}\text { Reall private cons } \\
\text { Private investme }\end{array}$ & $\begin{array}{l}3.5 \\
5.6\end{array}$ & $\begin{array}{l}0.1 \\
5.1\end{array}$ & 5.2 & $\begin{array}{l}0.5 \\
4.9\end{array}$ & $\begin{array}{l}.1 \\
4.9\end{array}$ & $\begin{array}{l}.8 \\
4.9\end{array}$ & 4.8 & $\begin{array}{l}1.0 \\
4.6\end{array}$ & $\begin{array}{l}1.0 \\
4.5\end{array}$ & 4.4 & 4.2 & 4.1 & $\begin{array}{l}0.8 \\
3.9\end{array}$ \\
\hline $\begin{array}{l}\text { Private investme } \\
\text { Private investme }\end{array}$ & 55.9 & 58.2 & 61.8 & 63.2 & 66.1 & 8 & 71.5 & $\begin{array}{r}4.0 \\
74.2\end{array}$ & $\begin{array}{r}4.9 \\
76.9\end{array}$ & $\begin{array}{l}79.5 \\
79.5\end{array}$ & $\begin{array}{l}4.2 .2 \\
82 .\end{array}$ & $\begin{array}{l}4.1 \\
84.9\end{array}$ & 88.0 \\
\hline diture) & 18.7 & $\begin{array}{l}0.6 \\
15.9\end{array}$ & $\begin{array}{l}14.2 \\
14.2\end{array}$ & 12.9 & & $\begin{array}{l}10.2 \\
10.2\end{array}$ & 9.0 & 7.7 & 6.6 & & 4.6 & ${ }_{3.6}^{+3.6}$ & $\begin{array}{r}88.0 \\
2.7\end{array}$ \\
\hline Healt & 17.7 & 17.6 & 17.6 & 17.6 & 17.6 & 6 & 17.6 & 17.6 & 17.6 & 17.6 & 17.6 & 17.6 & 17.6 \\
\hline istment) & 37.4 & 37.1 & 37.1 & 37.1 & 1 & .1 & 37.1 & 37.1 & 37.1 & 37.1 & 37.1 & 37.1 & 37.1 \\
\hline $\begin{array}{l}\text { ic investment) } \\
\text { esstment) }\end{array}$ & 10.7 & $\begin{array}{l}10.6 \\
34.7\end{array}$ & $\begin{array}{l}10.6 \\
34.7\end{array}$ & $\begin{array}{l}{ }_{34.6}^{10.6} \\
34.7\end{array}$ & $\begin{array}{l}{ }_{30.6}^{10.6} \\
34.7\end{array}$ & $\begin{array}{l}10.6 \\
34.7\end{array}$ & $\begin{array}{l}10.6 \\
34.7\end{array}$ & $\begin{array}{l}{ }_{30.6}^{10.6} \\
34.7\end{array}$ & $\begin{array}{l}10.6 \\
347\end{array}$ & 10.6 & $\begin{array}{l}10.6 \\
34.7\end{array}$ & 10.6 & 10.6 \\
\hline $\begin{array}{l}\text { pabilic investment) } \\
\text { revenue) }\end{array}$ & $\begin{array}{l}34.2 \\
51.9\end{array}$ & $\begin{array}{l}34.7 \\
53.7\end{array}$ & $\begin{array}{l}34.1 \\
54.5\end{array}$ & $\begin{array}{l}34.1 \\
55.6\end{array}$ & $\begin{array}{l}34.7 \\
56.6\end{array}$ & 7.5 & $\begin{array}{l}34.1 \\
58.4\end{array}$ & $\begin{array}{l}34.1 \\
59.1\end{array}$ & $\begin{array}{l}34.7 \\
59.8\end{array}$ & $\begin{array}{l}34.7 \\
60.4\end{array}$ & $\begin{array}{l}34.1 \\
60.8\end{array}$ & $\begin{array}{l}34.1 \\
61.3\end{array}$ & $\begin{array}{l}34.1 \\
61.7\end{array}$ \\
\hline vestment (\% of aid) & 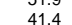 & $\begin{array}{l}34.2 \\
34.2\end{array}$ & $\begin{array}{l}29.9 \\
29.9\end{array}$ & $\begin{array}{l}53.0 \\
26.9\end{array}$ & 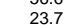 & 20.6 & $\begin{array}{l}10.4 \\
17.4\end{array}$ & 列 & $\begin{array}{l}39.7 \\
12.7\end{array}$ & 10.5 & $\begin{array}{l}80.6 \\
8.6\end{array}$ & 6.8 & $\begin{array}{r}61.1 \\
5.0\end{array}$ \\
\hline debt $(\%$ of GDP) & 7.7 & 8.2 & 8.9 & 9.5 & 10.1 & 10.6 & 11.1 & 11.6 & 12.1 & 12.6 & 13.1 & 13.6 & 14.1 \\
\hline External de & 83.9 & 80.5 & 80.1 & 79.3 & 78.1 & 77.0 & 75.8 & 74.6 & 73.6 & 72.6 & 71.7 & 70.7 & 69.8 \\
\hline : payment on external public debt $(0)$ & 6.3 & 6.5 & 6.5 & $\begin{array}{r}6.5 \\
43.5\end{array}$ & 6.6 & 6.7 & 6.7 & $\begin{array}{r}6.8 \\
38.9\end{array}$ & 6.9 & 7.0 & 7.0 & 7.0 & 7.0 \\
\hline $\begin{array}{l}\text { Degree of openeness (total traded in \% of GDP } \\
\text { Educated labor (in } \% \text { of population) }\end{array}$ & $\begin{array}{l}46.8 \\
17.1\end{array}$ & $\begin{array}{l}45.2 \\
17.1\end{array}$ & 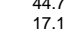 & $\begin{array}{l}43.5 \\
17.1\end{array}$ & $\begin{array}{l}42.3 \\
17.1\end{array}$ & $\begin{array}{l}41.1 \\
17.1\end{array}$ & $\begin{array}{l}39.9 \\
17.1\end{array}$ & $\begin{array}{l}38.9 \\
17.1\end{array}$ & $\begin{array}{l}38.1 \\
17.1\end{array}$ & $\begin{array}{l}37.4 \\
17.1\end{array}$ & $\begin{array}{l}36.9 \\
171\end{array}$ & $\begin{array}{l}36.4 \\
171\end{array}$ & $\begin{array}{l}36.0 \\
17 .\end{array}$ \\
\hline
\end{tabular}

Note: The real exchange rate is defined as the growth rate of nominal exchange rate plus the growth rate of the import price index minus the growth rate of composite good price after indirect taxes.
The "adjusted" elasticity formula proposed by Ravallion (2004) is $-9.3^{*}(1-$ Gini) $3=-1.13$ where Gini index is 50.5 for Niger. 
Table 4

Niger: 5 Percent Increase in Aid to GDP Ratio, 2003-15

\begin{tabular}{|c|c|c|c|c|c|c|c|c|c|c|c|c|c|}
\hline & \multicolumn{13}{|c|}{ Years } \\
\hline & 2003 & 2004 & 2005 & 2006 & 2007 & 2008 & 2009 & 2010 & 2011 & 2012 & 2013 & 2014 & 2015 \\
\hline \multicolumn{14}{|l|}{ Real Sector (in billions of current CFA francs) } \\
\hline $\begin{array}{l}\text { Total supply of goods and services } \\
\text { Gross domestic product at factor cost }\end{array}$ & $\begin{array}{l}0.00 \\
0.00\end{array}$ & $\begin{array}{l}1.49 \\
0.05\end{array}$ & $\begin{array}{l}1.96 \\
0.29\end{array}$ & $\begin{array}{l}2.39 \\
0.57\end{array}$ & $\begin{array}{l}2.88 \\
0.91\end{array}$ & $\begin{array}{l}3.42 \\
1.32\end{array}$ & $\begin{array}{l}4.00 \\
1.79\end{array}$ & $\begin{array}{l}4.63 \\
2.32\end{array}$ & $\begin{array}{l}5.36 \\
2.98\end{array}$ & ${ }_{3.66}^{6.11}$ & $\begin{array}{l}6.90 \\
4.33\end{array}$ & $\begin{array}{l}7.62 \\
4.85\end{array}$ & $\begin{array}{r}8.40 \\
5.42\end{array}$ \\
\hline Imports of goods and NFS (inclusive of tariffs) & 0.00 & 5.93 & 7.19 & 8.31 & 9.49 & 10.75 & 11.98 & 13.25 & 14.39 & 15.65 & 17.01 & 18.74 & 20.50 \\
\hline Total expenditure on goods and services & 0.00 & 1.50 & 1.96 & 2.40 & 2.88 & 3.42 & 4.00 & 4.63 & 5.36 & 6.12 & 6.90 & 7.61 & 8.39 \\
\hline Total consumption & 0.00 & -0.47 & -0.24 & 0.06 & 0.40 & 0.79 & 1.23 & 1.72 & 2.32 & 2.95 & 3.59 & 4.13 & 4.70 \\
\hline $\begin{array}{l}\text { Private consumption } \\
\text { Public spending on goods and services }\end{array}$ & 0.00 & $\begin{array}{r}-0.59 \\
0.20\end{array}$ & $\begin{array}{l}-0.35 \\
0.37\end{array}$ & $\begin{array}{r}-0.04 \\
0.60\end{array}$ & 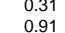 & $\begin{array}{l}0.70 \\
1.29\end{array}$ & $\begin{array}{l}1.13 \\
1.33\end{array}$ & $\frac{1.62}{2.24}$ & 2.21 & 2.84 & $\begin{array}{l}3.48 \\
4.25\end{array}$ & 4.01 & $\begin{array}{l}4.57 \\
5.39\end{array}$ \\
\hline 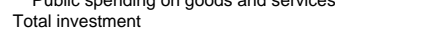 & 0.00 & 23.39 & 25.35 & 26.84 & 27.93 & $\begin{array}{l}1.29 \\
29.37\end{array}$ & 31.15 & 33.15 & 35.42 & 37.79 & $\begin{array}{r}4.25 \\
40.38\end{array}$ & $\begin{array}{l}4.19 \\
43.14\end{array}$ & $\begin{array}{r}5.39 \\
46.44\end{array}$ \\
\hline Private investment & 0.00 & -0.86 & 0.24 & 1.30 & 2.28 & 3.27 & 4.25 & 5.24 & 6.29 & 7.32 & 8.35 & 9.25 & $\begin{array}{l}40.44 \\
10.19\end{array}$ \\
\hline Public investment & 0.00 & 57.20 & 65.94 & 70.74 & 77.95 & 87.05 & 98.70 & 113.46 & 132.33 & 156.04 & 188.11 & 234.30 & 311.48 \\
\hline Exports of goods and NFS & 0.00 & 1.47 & 3.07 & 4.73 & 6.45 & 8.22 & 10.06 & 11.96 & 13.90 & 15.90 & 18.00 & 20.31 & 22.83 \\
\hline Gross domestic product at market prices & 0.00 & 0.20 & 0.37 & 0.59 & 0.90 & 1.28 & 1.73 & 2.25 & 2.90 & 3.57 & 4.25 & 4.79 & 5.39 \\
\hline Disposable income & 0.00 & 0.12 & 0.44 & 0.79 & 1.19 & 1.65 & 2.16 & 2.72 & 3.42 & 4.12 & 4.82 & 5.35 & 5.94 \\
\hline \multicolumn{14}{|l|}{ Poverty rate } \\
\hline $\begin{array}{l}\text { Ravallion's (2004) adjusted elasticity (Gini }=50.5 \text { ) } \\
\text { Consumption per capita growth elasticitiof of }-0.5\end{array}$ & $\begin{array}{l}0.00 \\
0.00\end{array}$ & $\begin{array}{l}-0.27 \\
-0.12\end{array}$ & $\begin{array}{l}-0.59 \\
-0.26\end{array}$ & $\begin{array}{l}-0.94 \\
-0.42\end{array}$ & $\begin{array}{l}-1.33 \\
-0.59\end{array}$ & $\begin{array}{l}-1.73 \\
-0.78\end{array}$ & $\begin{array}{l}-2.16 \\
-0.98\end{array}$ & $\begin{array}{l}-2.59 \\
-1.19\end{array}$ & $\begin{array}{r}-3.05 \\
-1.41\end{array}$ & $\begin{array}{l}-3.51 \\
-1.63\end{array}$ & $\begin{array}{l}-3.98 \\
-1.86\end{array}$ & $\begin{array}{l}-4.43 \\
-2.09\end{array}$ & $\begin{array}{l}-4.88 \\
-2.32\end{array}$ \\
\hline Consumption per capita growth elasticity of -1.0 & 0.00 & -0.24 & -0.52 & $\begin{array}{l}-0.42 \\
-0.84\end{array}$ & -1.18 & -1.54 & -1.92 & -2.31 & -2.72 & -3.14 & $\begin{array}{l}-1.00 \\
-3.56\end{array}$ & -3.97 & -4.38 \\
\hline Consumption per capita growth elasticity of -1.5 & 0.00 & -0.35 & -0.78 & -1.25 & -1.75 & -2.28 & -2.82 & -3.37 & -3.95 & -4.53 & -5.11 & -5.66 & -6.21 \\
\hline \multicolumn{14}{|l|}{ External Sector (\% of GDP) } \\
\hline Current account & 0.00 & 3.80 & 3.85 & 3.97 & 4.10 & 4.23 & 4.37 & 4.52 & 4.69 & 4.84 & 4.98 & 5.06 & 5.17 \\
\hline Trade balance & 0.00 & -1.21 & -1.23 & -1.16 & -1.10 & -1.03 & -0.95 & -0.87 & -0.76 & -0.67 & -0.60 & -0.57 & -0.51 \\
\hline Exports of goods and NFS & 0.00 & 0.19 & 0.42 & 0.63 & 0.83 & 1.01 & 1.18 & 1.34 & 1.48 & 1.62 & 1.78 & 1.97 & 2.18 \\
\hline Imports of goods and NFS & 0.00 & 1.41 & 1.64 & 1.79 & 1.92 & 2.04 & 2.13 & 2.21 & 2.24 & 2.30 & 2.37 & 2.54 & 2.70 \\
\hline $\begin{array}{l}\text { Private unrequited transfers } \\
\text { Income net) }\end{array}$ & $\begin{array}{l}0.00 \\
0.00\end{array}$ & $\begin{array}{l}0.00 \\
0.00\end{array}$ & $\begin{array}{l}0.00 \\
0.05\end{array}$ & 0.00 & -0.015 & $\begin{array}{r}-0.01 \\
0.19\end{array}$ & -0.01 & 0.028 & -0.02 & -0.02 & -0.03 & -0.03 & -0.03 \\
\hline $\begin{array}{l}\text { Income (net) } \\
\text { Public }\end{array}$ & 0.00 & 0.00 & 0.05 & 0.10 & 0.15 & $\begin{array}{l}0.19 \\
0.20\end{array}$ & $\begin{array}{l}0.23 \\
0.24\end{array}$ & 0.29 & 0.33 & 0.38 & 0.42 & 0.46 & 0.49 \\
\hline Private & 0.00 & 0.00 & 0.00 & 0.00 & 0.00 & -0.01 & -0.01 & -0.01 0.09 & -0.01 & -0.01 & -0.01 & $\begin{array}{c}.0 .40 \\
-0.02\end{array}$ & $\begin{aligned} 0.51 \\
-0.02\end{aligned}$ \\
\hline Aid, total & 0.00 & 5.00 & 5.00 & 5.00 & 5.00 & 5.00 & 5.00 & 5.00 & 5.00 & 5.00 & 5.00 & 500 & 500 \\
\hline Other current account flows (net) & 0.00 & 0.01 & 0.03 & 0.04 & 0.06 & 0.08 & 0.10 & 0.12 & 0.15 & 0.17 & 0.20 & 0.21 & 0.23 \\
\hline Capital account & 0.00 & -3.04 & -2.97 & -3.01 & -3.06 & -3.12 & -3.18 & -3.25 & -3.31 & -3.38 & -3.46 & -3.55 & -3.64 \\
\hline Private borrowing & 0.00 & 0.00 & 0.00 & 0.00 & 0.00 & 0.00 & 0.00 & -0.01 & -0.01 & -0.01 & -0.01 & -0.01 & -0.01 \\
\hline Public borrowing & 0.00 & -3.01 & -2.94 & -2.98 & -3.03 & -3.08 & -3.14 & -3.21 & -3.27. & -3.34 & -3.42 & -3.51 & -3.59 \\
\hline Errors and omissions & 0.00 & -0.03 & -0.03 & -0.03 & -0.03 & -0.03 & -0.03 & -0.03 & -0.04 & -0.04 & -0.04 & -0.04 & -0.04 \\
\hline \multicolumn{14}{|l|}{ Government Sector (\% of GDP) } \\
\hline & 0.00 & 5.05 & 4.91 & 4.78 & 4.68 & 4.60 & 4.53 & 4.47 & 4.41 & 4.37 & 4.33 & 4.32 & 4.32 \\
\hline Domestic taxes & 0.00 & -0.24 & -0.44 & -0.60 & -0.72 & -0.83 & -0.92 & -0.99 & -1.06 & -1.11 & -1.16 & -1.21 & -1.25 \\
\hline Direct taxes & 0.00 & -0.11 & -0.19 & -0.27 & -0.34 & -0.41 & -0.47 & -0.53 & -0.58 & -0.63 & -0.67 & -0.71 & -0.75 \\
\hline Indirect taxes & 0.00 & 0.14 & -0.25 & -0.32 & -0.38 & -0.42 & -0.44 & -0.46 & -0.48 & -0.49 & -0.49 & -0.50 & -0.50 \\
\hline $\begin{array}{l}\text { Indirect taxes on imports } \\
\text { Foreing aid (arants) }\end{array}$ & 0.00 & 0.29 & 0.34 & 0.37 & 0.40 & 0.43 & 0.45 & 0.46 & 0.47 & 0.48 & 0.50 & 0.53 & 0.56 \\
\hline $\begin{array}{l}\text { Foreign add (granits) } \\
\text { Total expenditure }\end{array}$ & 0.00 & 2.04 & $\begin{array}{l}5.00 \\
1.98\end{array}$ & 1.84 & $\begin{array}{l}5.00 \\
1.70\end{array}$ & 1.56 & $\begin{array}{l}5.00 \\
1.44\end{array}$ & $\begin{array}{l}5.30 \\
1.32\end{array}$ & $\begin{array}{l}5.00 \\
1.20\end{array}$ & 100 & 5.00 & 5.00 & 5.00 \\
\hline Spending on goods and services & 0.00 & 0.00 & 0.00 & 0.00 & 0.00 & 0.00 & 0.00 & 0.00 & 0.00 & 0.00 & 0.00 & 0.00 & $\begin{array}{l}0.19 \\
0.00\end{array}$ \\
\hline $\begin{array}{l}\text { Waes and salaries } \\
\text { Watures }\end{array}$ & 0.00 & -0.04 & -0.05 & -0.07 & -0.08 & -0.10 & -0.12 & -0.14 & -0.17 & -0.19 & -0.21 & -0.24 & -0.26 \\
\hline Investment & 0.00 & 2.08 & 2.09 & 2.00 & 1.93 & 1.86 & 1.80 & 1.75 & 1.70 & 1.66 & 1.62 & 1.58 & 1.56 \\
\hline Interest payments & 0.00 & 0.00 & -0.05 & -0.10 & -0.15 & -0.20 & -0.24 & -0.29 & -0.33 & -0.38 & -0.42 & -0.47 & -0.51 \\
\hline Domestic debt & 0.00 & 0.00 & 0.00 & 0.00 & 0.00 & 0.00 & 0.00 & 0.00 & 0.00 & 0.00 & 0.00 & 0.00 & -0.01 \\
\hline Foreign debt & 0.00 & 0.00 & -0.05 & -0.10 & -0.15 & -0.20 & -0.24 & -0.29 & -0.33 & -0.38 & -0.42 & -0.46 & -0.51 \\
\hline Overall fisc & 0.00 & 3.01 & 2.94 & 2.98 & 3.03 & 3.08 & 3.14 & 3.21 & 3.27 & 3.34 & 3.42 & 3.51 & 3.59 \\
\hline $\begin{array}{l}\text { Total financing } \\
\text { Foreign financing }\end{array}$ & $\begin{array}{l}0.00 \\
0.00\end{array}$ & $\begin{array}{l}-3.01 \\
-3.01\end{array}$ & $\begin{array}{l}-2.94 \\
-2.94\end{array}$ & $\begin{array}{l}-2.98 \\
-2.98\end{array}$ & 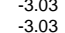 & $\begin{array}{l}-3.08 \\
-3.08\end{array}$ & $\begin{array}{l}-3.14 \\
-3.14\end{array}$ & $\begin{array}{l}-3.21 \\
-3.21\end{array}$ & -3.27 & $\begin{array}{l}-3.34 \\
-3434\end{array}$ & $\begin{array}{r}-3.42 \\
-3.42\end{array}$ & $\begin{array}{l}-3.51 \\
-3.51\end{array}$ & $\begin{array}{r}-3.59 \\
-3.59 \\
\end{array}$ \\
\hline $\begin{array}{l}\text { Foreign tinananing } \\
\text { Domestic borrowing }\end{array}$ & $\begin{array}{l}0.00 \\
0.00\end{array}$ & $\begin{array}{r}-3.01 \\
0.00\end{array}$ & $\begin{array}{r}-2.94 \\
0.00\end{array}$ & $\begin{array}{r}-2.98 \\
0.00\end{array}$ & $\begin{array}{l}-3.03 \\
0.00\end{array}$ & $\begin{array}{r}-3.08 \\
0.00\end{array}$ & $\begin{array}{r}-3.14 \\
0.00\end{array}$ & $\begin{array}{r}-3.21 \\
0.00\end{array}$ & 0.00 & 0.00 & $\begin{array}{r}-3.42 \\
0.00\end{array}$ & $\begin{array}{c}-3.51 \\
0.00\end{array}$ & 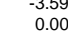 \\
\hline \multicolumn{14}{|l|}{ Prices and Real Excha } \\
\hline GDP at factor & 0.00 & 0.05 & 0.23 & 0.22 & 0.21 & 0.20 & 0.18 & 0.17 & 0.24 & 0.20 & 0.15 & -0.04 & -0.01 \\
\hline Composite good price (after indire & 0.00 & -1.11 & -0.30 & -0.28 & -0.26 & -0.25 & -0.25 & -0.23 & -0.17 & -0.17 & -0.18 & -0.28 & -0.26 \\
\hline Real exchange rate (\% change) & 0.00 & 1.11 & 0.30 & 0.28 & 0.26 & 0.25 & 0.25 & 0.23 & 0.17 & 0.17 & 0.18 & 0.28 & 0.26 \\
\hline \multicolumn{14}{|l|}{ Memorandum items } \\
\hline Real GDP per capita at factor cost ( $\%$ change) & 0.00 & 0.00 & 0.00 & 0.06 & 0.13 & 0.22 & 0.29 & 0.37 & 0.43 & 0.48 & 0.52 & 0.56 & 0.59 \\
\hline Real GDP per capita at market prices (\% change) & 0.00 & 1.33 & 0.47 & 0.51 & 0.58 & 0.65 & 0.72 & 0.75 & 0.83 & 0.85 & 0.87 & 0.82 & 0.86 \\
\hline Real dispos & 0.00 & 1.23 & 0.63 & 0.65 & 0.68 & 0.72 & 0.78 & 0.80 & 0.88 & 0.88 & 0.88 & 0.81 & 0.84 \\
\hline Private savings rate & 0.00 & -0.01 & 0.01 & 0.02 & 0.03 & 0.03 & 0.04 & 0.04 & 0.05 & 0.05 & 0.05 & 0.05 & $0.05>2>3$ \\
\hline Real private consumption per capita ( $\%$ change) & 0.00 & 0.37 & 0.45 & 0.51 & 0.57 & 0.61 & 0.65 & 0.69 & 0.75 & 0.78 & 0.80 & 0.80 & 0.81 \\
\hline Private investment (\% of GDP) & 0.00 & -0.05 & -0.01 & 0.03 & 0.07 & 0.10 & 0.12 & 0.14 & 0.15 & 0.16 & 0.17 & 0.17 & 0.18 \\
\hline Private investment (\% of & 0.00 & -11.45 & -12.38 & -12.73 & -13.25 & 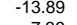 & -14.67 & -15.56 & -16.54 & -17.58 & -18.75 & -20.11 & -21.78 \\
\hline $\begin{array}{l}\text { Public investment (\% of total pub } \\
\text { Healts }\end{array}$ & 0.00 & 7.01 & 7.37 & 7.35 & 7.36 & 7.39 & 7.43 & 7.46 & 7.47 & 7.47 & 7.47 & 7.49 & 7.55 \\
\hline $\begin{array}{l}\text { Health (\% of public investment) } \\
\text { Infrastructure }(0 \% \text { of public investment) }\end{array}$ & $\begin{array}{l}0.00 \\
0.00\end{array}$ & $\begin{array}{l}0.00 \\
0.00\end{array}$ & $\begin{array}{l}0.00 \\
0.00\end{array}$ & $\begin{array}{l}0.00 \\
0.00\end{array}$ & $\begin{array}{l}0.00 \\
0.00\end{array}$ & $\begin{array}{l}0.00 \\
0.00\end{array}$ & $\begin{array}{l}0.00 \\
0.00\end{array}$ & $\begin{array}{l}0.00 \\
0.00\end{array}$ & 0.00 & $\begin{array}{l}0.00 \\
0.00\end{array}$ & $\begin{array}{l}0.00 \\
0.00\end{array}$ & 0.000 & $\begin{array}{l}0.00 \\
0.00\end{array}$ \\
\hline Education (\% of public investment) & 0.00 & 0.00 & 0.00 & 0.00 & 0.00 & 0.00 & 0.00 & 0.00 & 0.00 & 0.00 & 0.00 & 00 & 0.00 \\
\hline Other ( $\%$ of public investment) & 0.00 & 0.00 & 0.00 & 0.00 & 0.00 & 0.00 & 0.00 & 0.00 & 0.00 & 0.00 & 0.00 & 0.00 & 0.00 \\
\hline 6 of total revenu & 0.00 & 9.18 & 9.50 & 9.77 & 9.99 & 10.17 & 10.33 & 10.47 & 10.61 & 10.73 & 10.81 & 10.81 & 10.81 \\
\hline$\%$ of aid) & 0.00 & 2.34 & 3.77 & 4.19 & 4.75 & 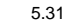 & 5.85 & 6.36 & 6.82 & 7.20 & 7.57 & 7.94 & 8.36 \\
\hline Domestic debt (\% of GDP) & 0.00 & -0.01 & -0.03 & -0.04 & -0.07 & -0.10 & -0.14 & -0.19 & -0.25 & -0.31 & -0.38 & -0.43 & -0.48 \\
\hline al debt (\% of GDP) & 0.00 & -3.17 & -6.12 & -8.99 & -11.82 & -14.60 & -17.34 & -20.06 & -22.81 & -25.53 & -28.24 & -30.84 & -33.47 \\
\hline Interest payment on external pub & 0.00 & -0.09 & -0.51 & -0.90 & -1.29 & -1.67 & -2.06 & -2.45 & -2.83 & -3.20 & -3.57 & -3.94 & -4.29 \\
\hline Degree of openness (total trade it & 0.00 & 1.90 & 2.40 & 2.79 & 3.15 & 3.47 & 3.75 & 4.0 & 4.19 & 4.40 & 4.65 & 5.04 & 5.45 \\
\hline Educated labor (in \% of population & 0.00 & 0.00 & 0.00 & 0.00 & 0.00 & 0.00 & 0.00 & 0.00 & 0.00 & 0.00 & 0.00 & 0.00 & 0.00 \\
\hline
\end{tabular}


Table 5

Niger: 20 Percent Decrease in "Other" Investment in Percent of Total Public Investment
Allocated to 20 Percent Increase in Infrastucture Investment in Percent of Total Public Investment, 2003-15

\begin{tabular}{|c|c|c|c|c|c|c|c|c|c|c|c|c|c|}
\hline & \multicolumn{13}{|c|}{ Years } \\
\hline & 2003 & 2004 & 2005 & 2006 & 2007 & 2008 & 2009 & 2010 & 2011 & 2012 & 2013 & 2014 & 2015 \\
\hline \multicolumn{14}{|l|}{ Real Sector (in billions of current CFA francs) } \\
\hline $\begin{array}{l}\text { Totall supply of goods and services } \\
\text { Gross domestic product at factor cost }\end{array}$ & $\begin{array}{l}0.00 \\
0.00\end{array}$ & $\begin{array}{l}0.00 \\
0.00\end{array}$ & $\begin{array}{l}0.04 \\
0.00\end{array}$ & $\begin{array}{l}0.10 \\
0.05\end{array}$ & $\begin{array}{l}0.18 \\
0.13\end{array}$ & $\begin{array}{l}0.28 \\
0.25\end{array}$ & $\begin{array}{l}0.40 \\
0.41\end{array}$ & $\begin{array}{l}0.54 \\
0.60\end{array}$ & $\begin{array}{l}0.67 \\
0.78\end{array}$ & $\begin{array}{l}0.81 \\
0.96\end{array}$ & $\begin{array}{l}0.95 \\
1.15\end{array}$ & $\begin{array}{l}1.10 \\
1.36\end{array}$ & 1.23 \\
\hline Imports of goods and NFS (inclusive of tariffs) & 0.00 & 0.00 & 0.15 & 0.27 & 0.33 & 0.36 & 0.35 & 0.31 & 0.27 & 0.22 & 0.15 & 0.05 & $\begin{array}{r}1.55 \\
-0.07\end{array}$ \\
\hline Total expenditure on goods and services & 0.00 & 0.00 & 0.04 & 0.10 & 0.18 & 0.28 & 0.40 & 0.54 & 0.67 & 0.81 & 0.96 & 1.09 & 1.23 \\
\hline $\begin{array}{l}\text { Total consumption } \\
\text { Private consumption }\end{array}$ & $\begin{array}{l}0.00 \\
0.00\end{array}$ & $\begin{array}{l}0.00 \\
0.00\end{array}$ & $\begin{array}{l}-0.01 \\
-0.02\end{array}$ & 0.00 & 0.05 & 0.13 & 0.25 & 0.40 & 0.56 & 0.73 & 0.92 & 1.10 & 1.30 \\
\hline & 0.00 & 0.00 & 0.01 & $\begin{array}{r}-0.01 \\
0.06\end{array}$ & $\begin{array}{l}0.03 \\
0.14\end{array}$ & 0.26 & 0.41 & 0.59 & $\begin{array}{l}0.52 \\
0.76\end{array}$ & 0.95 & $\begin{array}{l}0.88 \\
1.14\end{array}$ & $\begin{array}{l}1.06 \\
1.32\end{array}$ & 1.26 \\
\hline $\begin{array}{l}\text { Pubbic speniding on goods and services } \\
\text { Total investment }\end{array}$ & 0.00 & 0.00 & 0.66 & 1.32 & 1.91 & 2.48 & $\begin{array}{l}3.41 \\
3.01\end{array}$ & 3.48 & $\begin{array}{l}0.10 \\
3.88\end{array}$ & 4.23 & $\begin{array}{ll}1.14 \\
4.52\end{array}$ & $\begin{array}{l}1.32 \\
4.73\end{array}$ & $\begin{array}{l}1.51 \\
4.86\end{array}-10$ \\
\hline Private investment & 0.00 & 0.00 & 1.10 & 2.08 & 2.89 & 3.64 & 4.34 & 4.96 & 5.49 & 5.94 & 6.32 & 6.62 & 6.84 \\
\hline Public investment & 0.00 & 0.00 & -0.04 & 0.01 & 0.02 & -0.09 & -0.34 & -0.77 & -1.46 & -2.41 & -3.82 & -5.94 & -9.63 \\
\hline Exports of goods and NFS & 0.00 & 0.00 & 0.03 & 0.09 & 0.13 & 0.17 & 0.17 & 0.15 & 0.09 & 0.00 & -0.13 & -0.29 & -0.49 \\
\hline $\begin{array}{l}\text { Gross domestic product at market prices } \\
\text { Dissosable income }\end{array}$ & $\begin{array}{l}0.00 \\
0.00\end{array}$ & $\begin{array}{l}0.00 \\
0.00\end{array}$ & $\begin{array}{l}0.01 \\
0.00\end{array}$ & $\begin{array}{l}0.06 \\
0.04\end{array}$ & 0.14 & $\begin{array}{l}0.26 \\
024\end{array}$ & $\begin{array}{l}0.41 \\
0.40\end{array}$ & $\begin{array}{l}0.59 \\
0.58\end{array}$ & 0.77 & 0.95 & 1.13 & 1.33 & 1.51 \\
\hline Disposable income & 0.00 & 0.00 & 0.00 & 0.04 & 0.12 & 0.24 & 0.40 & 0.58 & 0.75 & 0.93 & 1.12 & 1.32 & 1.51 \\
\hline \multicolumn{14}{|l|}{ Poverty rate } \\
\hline $\begin{array}{l}\text { Ravallion's }(2004) \text { adjusted elasticity }(G i n i=50.5) \\
\text { Consumption per capita growth elasticity of }-0.5\end{array}$ & 0.00 & $\begin{array}{l}0.00 \\
0.00\end{array}$ & $\begin{array}{c}-0.01 \\
0.00\end{array}$ & $\begin{array}{l}-0.02 \\
-0.01\end{array}$ & -0.05 & -0.09 & -0.14 & 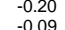 & -0.27 & -0.34 & -0.41 & -0.48 & -0.54 \\
\hline Consumption per capita growth elasticity of -1.0 & 0.00 & 0.00 & -0.01 & $\begin{array}{l}-0.01 \\
-0.02\end{array}$ & $\begin{array}{l}-0.02 \\
-0.04\end{array}$ & $\begin{array}{l}-0.04 \\
-0.08\end{array}$ & -0.13 & -0.18 & $\begin{array}{l}-0.24 \\
-0.24\end{array}$ & $\begin{array}{l}-0.10 \\
-0.30\end{array}$ & $\begin{array}{l}-0.19 \\
-0.37\end{array}$ & $\begin{array}{l}-0.22 \\
-0.43\end{array}$ & $\begin{array}{l}-0.49 \\
-0.49\end{array}$ \\
\hline Consumption per capita growth elasticity of -1.5 & 0.00 & 0.00 & -0.01 & $\begin{aligned}-0.03 \\
-0.03\end{aligned}$ & -0.07 & -0.12 & -0.19 & -0.27 & -0.35 & -0.44 & -0.53 & $\begin{array}{r}-0.62 \\
-0.62\end{array}$ & 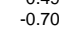 \\
\hline \multicolumn{14}{|l|}{ External Sector (\% of GDP) } \\
\hline $\begin{array}{l}\text { Current account } \\
\text { Trade halance }\end{array}$ & 0.00 & 0.00 & -0.03 & -0.04 & -0.04 & -0.02 & 0.00 & 0.03 & 0.05 & 0.06 & 0.08 & 0.09 & 0.10 \\
\hline $\begin{array}{l}\text { Traae Dalance } \\
\text { Exports of goods and NFS }\end{array}$ & 0.00 & 0.00 & 0.00 & $\begin{array}{r}-0.04 \\
0.00\end{array}$ & $\begin{array}{r}-0.04 \\
0.00\end{array}$ & $\begin{array}{l}-0.04 \\
-0.01\end{array}$ & -0.03 & $\begin{array}{l}-0.01 \\
-0.06\end{array}$ & 0.01 & . & 0.02 & 0.03 & 0.03 \\
\hline Imports of goods and NFS & 0.00 & 0.00 & 0.03 & 0.05 & 0.04 & 0.02 & -0.01 & -0.06 & -0.10 & -0.14 & -0.19 & -0.24 & -0.29 \\
\hline Private unrequited transfers & 0.00 & 0.00 & 0.00 & 0.00 & 0.00 & 0.00 & 0.00 & 0.00 & 0.00 & -0.01 & -0.01 & -0.01 & -0.01 \\
\hline Income (net) & 0.00 & 0.00 & 0.00 & 0.00 & 0.00 & 0.00 & 0.00 & 0.00 & 0.01 & 0.01 & 0.01 & 0.01 & 0.01 \\
\hline Public & 0.00 & 0.00 & 0.00 & 0.00 & 0.00 & 0.00 & 0.00 & 0.01 & 0.01 & 0.01 & 0.01 & 0.01 & 0.02 \\
\hline Private & 0.00 & 0.00 & 0.00 & 0.00 & 0.00 & 0.00 & 0.00 & 0.00 & 0.00 & 0.00 & 0.00 & 0.00 & -0.01 \\
\hline Aid, total & 0.00 & 0.00 & 0.00 & 0.00 & 0.00 & 0.00 & 0.00 & 0.00 & 0.00 & 0.00 & 0.00 & 0.00 & 0.00 \\
\hline Other current account flows (net) & 0.00 & 0.00 & 0.00 & 0.00 & 0.01 & 0.02 & 0.02 & 0.03 & 0.04 & 0.05 & 0.05 & 0.06 & 0.07 \\
\hline Capital account & 0.00 & 0.00 & -0.01 & -0.02 & -0.02 & -0.03 & -0.03 & -0.04 & -0.04 & -0.05 & -0.05 & -0.05 & -0.05 \\
\hline Private borrowing & 0.00 & 0.00 & 0.00 & 0.00 & 0.00 & 0.00 & 0.00 & 0.00 & 0.00 & 0.00 & 0.00 & 0.00 & 0.00 \\
\hline Public borrowing & 0.00 & 0.00 & -0.01 & -0.02 & -0.02 & -0.03 & -0.03 & -0.03 & -0.04 & -0.04 & -0.04 & -0.05 & -0.05 \\
\hline Errors and omissions & 0.00 & 0.00 & 0.00 & 0.00 & 0.00 & 0.00 & 0.00 & 0.00 & 0.00 & 0.00 & 0.00 & 0.00 & 0.00 \\
\hline \multicolumn{14}{|l|}{ Government Sector (\% of GDP) } \\
\hline $\begin{array}{l}\text { Total revenue (including grants) } \\
\text { Domestit caxes }\end{array}$ & $\begin{array}{l}0.00 \\
0.00\end{array}$ & $\begin{array}{l}0.00 \\
0.00\end{array}$ & $\begin{array}{l}0.01 \\
0.00\end{array}$ & $\begin{array}{l}0.01 \\
0.00\end{array}$ & $\begin{array}{l}0.01 \\
0.00\end{array}$ & $\begin{array}{l}0.00 \\
0.00\end{array}$ & $\begin{array}{l}0.00 \\
0.00\end{array}$ & $\begin{array}{r}-0.01 \\
0.00\end{array}$ & $\begin{array}{r}-0.02 \\
0.00\end{array}$ & $\begin{array}{l}-0.03 \\
0.00\end{array}$ & $\begin{array}{r}-0.04 \\
0.00\end{array}$ & $\begin{array}{r}-0.05 \\
0.00\end{array}$ & $\begin{array}{c}-0.06 \\
0.00\end{array}$ \\
\hline $\begin{array}{l}\text { Domestic taxes } \\
\text { Direct taxes }\end{array}$ & 0.00 & 0.00 & 0.00 & 0.00 & 0.00 & 0.00 & 0.00 & 0.00 & 0.00 & 0.00 & 0.00 & 0.00 & 0.00 \\
\hline Indirect taxes & 0.00 & 0.00 & 0.00 & 0.00 & 0.00 & 0.00 & 0.00 & 0.00 & 0.00 & 0.00 & 0.00 & 0.00 & 0.00 \\
\hline Indirect taxes on imports & 0.00 & 0.00 & 0.01 & 0.01 & 0.01 & 0.00 & 0.00 & -0.01 & -0.02 & -0.03 & -0.04 & -0.05 & -0.06 \\
\hline Foreign aid (grants) & 0.00 & 0.00 & 0.00 & 0.00 & 0.00 & 0.00 & 0.00 & 0.00 & 0.00 & 0.00 & 0.00 & 0.00 & 0.00 \\
\hline Total expenditure & 0.00 & 0.00 & 0.00 & -0.01 & -0.01 & -0.02 & -0.03 & -0.05 & -0.06 & -0.07 & -0.08 & -0.10 & -0.11 \\
\hline Spending on goods and services & 0.00 & 0.00 & 0.00 & 0.00 & 0.00 & 0.00 & 0.00 & 0.00 & 0.00 & 0.00 & 0.00 & 0.00 & 0.00 \\
\hline Wages and salaries & 0.00 & 0.00 & 0.00 & 0.00 & -0.01 & -0.01 & -0.01 & -0.02 & -0.02 & -0.02 & -0.03 & -0.03 & -0.03 \\
\hline Investment & 0.00 & 0.00 & 0.00 & 0.00 & 0.00 & -0.01 & -0.01 & -0.02 & -0.03 & -0.04 & -0.04 & -0.05 & -0.06 \\
\hline Interest payments & 0.00 & 0.00 & 0.00 & 0.00 & 0.00 & 0.00 & -0.01 & -0.01 & -0.01 & -0.01 & -0.01 & -0.02 & -0.02 \\
\hline Domestic debt & 0.00 & 0.00 & 0.00 & 0.00 & 0.00 & 0.00 & 0.00 & 0.00 & 0.00 & 0.00 & 0.00 & 0.00 & 0.00 \\
\hline Foreign debt & 0.00 & 0.00 & 0.00 & 0.00 & 0.00 & 0.00 & 0.00 & -0.01 & -0.01 & -0.01 & -0.01 & -0.01 & -0.02 \\
\hline Overall fiscal balance & 0.00 & 0.00 & 0.01 & 0.02 & 0.02 & 0.03 & 0.03 & 0.03 & 0.04 & 0.04 & 0.04 & 0.05 & 0.05 \\
\hline $\begin{array}{l}\text { Total financing } \\
\text { Foringn financing }\end{array}$ & 0.00 & 0.00 & -0.01 & $\begin{array}{l}-0.02 \\
-0.02\end{array}$ & -0.02 & -0.03 & -0.03 & $\begin{array}{r}-0.03 \\
-0.03\end{array}$ & $\begin{array}{l}-0.04 \\
-0.04\end{array}$ & -0.04 & -0.04 & -0.05 & -0.05 \\
\hline $\begin{array}{l}\text { Foreign nitananing } \\
\text { Domestic borrowing }\end{array}$ & $\begin{array}{l}0.00 \\
0.00\end{array}$ & $\begin{array}{l}0.00 \\
0.00\end{array}$ & $\begin{array}{r}-0.01 \\
0.00\end{array}$ & $\begin{array}{r}-0.02 \\
0.00\end{array}$ & $\begin{array}{r}-0.02 \\
0.00\end{array}$ & $\begin{array}{r}-0.03 \\
0.00\end{array}$ & $\begin{array}{l}-0.03 \\
0.00\end{array}$ & $\begin{array}{r}-0.03 \\
0.00\end{array}$ & $\begin{array}{r}-0.04 \\
0.00\end{array}$ & $\begin{array}{l}-0.04 \\
-0.00\end{array}$ & $\begin{array}{r}-0.04 \\
0.00\end{array}$ & $\begin{array}{r}-0.05 \\
0.00\end{array}$ & $\begin{array}{r}-0.05 \\
0.00\end{array}$ \\
\hline \multicolumn{14}{|l|}{ Prices and Real Excha } \\
\hline GDP at factor cost deflato & 0.00 & 0.00 & 0.00 & 0.00 & -0.01 & -0.03 & -0.04 & -0.06 & -0.09 & -0.10 & -0.11 & -0.09 & -0.10 \\
\hline Composite good price (after indire & 0.00 & 0.00 & -0.03 & -0.01 & 0.00 & 0.02 & 0.04 & 0.05 & 0.05 & 0.06 & 0.07 & 0.08 & 0.09 \\
\hline Real exchange rate (\% change) & 0.00 & 0.00 & 0.03 & 0.01 & 0.00 & -0.02 & -0.04 & -0.05 & -0.05 & -0.06 & -0.07 & -0.08 & -0.09 \\
\hline \multicolumn{14}{|l|}{$\begin{array}{l}\text { Memorandum items } \\
\text {. }\end{array}$} \\
\hline Real GDP per capita at factor cost (\% change) & 0.00 & 0.00 & 0.00 & 0.04 & 0.10 & 0.16 & 0.22 & 0.26 & 0.28 & 0.30 & 0.31 & 0.31 & 0.30 \\
\hline Real GDP per capita at market prices (\% change) & 0.00 & 0.00 & 0.04 & 0.06 & 0.08 & 0.11 & 0.12 & 0.13 & 0.13 & 0.13 & 0.11 & 0.13 & 0.11 \\
\hline Rea & 0.00 & 0.00 & 0.03 & 0.05 & 0.08 & 0.11 & 0.12 & 0.13 & 0.13 & 0.13 & 0.11 & 0.13 & 0.11 \\
\hline Private savings rat & 0.00 & 0.00 & 0.00 & 0.00 & 0.00 & 0.00 & 0.00 & 0.00 & 0.00 & 0.00 & 0.00 & 0.00 & 0.00 \\
\hline capita (\% change) & 0.00 & 0.00 & 0.01 & 0.02 & 0.04 & 0.06 & 0.08 & 0.09 & 0.10 & 0.11 & 0.11 & 0.11 & 0.11 \\
\hline Private investment (\% of GDP) & 0.00 & 0.00 & 0.06 & 0.10 & 0.13 & 0.16 & 0.19 & 0.20 & 0.21 & 0.22 & 0.22 & 0.21 & 0.21 \\
\hline Private investment $(\%$ of total investment) & 0.00 & 0.00 & 0.27 & 0.47 & 0.63 & 0.78 & 0.92 & 1.06 & 1.19 & 1.31 & 1.42 & 1.53 & 1.66 \\
\hline Public investment $(\%$ of total public expenditure) & 0.00 & 0.00 & -0.01 & $\begin{array}{l}0.00 \\
0.00\end{array}$ & -0.01 & -0.03 & -0.05 & -0.09 & -0.13 & -0.17 & -0.21 & -0.24 & -0.29 \\
\hline $\begin{array}{l}\text { Health } \% \text { of public investment) } \\
\text { lntrastructure (\% of pothic investment) }\end{array}$ & 0.00 & $\begin{array}{r}0.00 \\
20.00\end{array}$ & $\begin{array}{r}0.00 \\
2000\end{array}$ & $\begin{array}{r}0.00 \\
2000\end{array}$ & $\begin{array}{r}0.00 \\
20.00\end{array}$ & $\begin{array}{r}0.00 \\
20.00\end{array}$ & 2000 & $\begin{array}{r}0.00 \\
2000\end{array}$ & 20.00 & $\begin{array}{r}0.00 \\
2000\end{array}$ & 20.00 & $\begin{array}{r}0.00 \\
20.00\end{array}$ & 0.00 \\
\hline $\begin{array}{l}\text { Intrasstructure (\% of pubblic Investment) } \\
\text { Education (\% of public investment) }\end{array}$ & $\begin{array}{l}0.00 \\
0.00\end{array}$ & $\begin{array}{r}20.00 \\
0.00\end{array}$ & $\begin{array}{r}20.00 \\
0.00\end{array}$ & $\begin{array}{r}20.00 \\
0.00\end{array}$ & $\begin{array}{r}20.00 \\
0.00\end{array}$ & $\begin{array}{r}20.00 \\
0.00\end{array}$ & $\begin{array}{r}20.00 \\
0.00\end{array}$ & $\begin{array}{r}20.00 \\
0.00\end{array}$ & $\begin{array}{r}20.00 \\
0.00\end{array}$ & $\begin{array}{r}20.00 \\
0.00\end{array}$ & $\begin{array}{r}20.00 \\
0.00\end{array}$ & $\begin{array}{r}20.00 \\
0.00\end{array}$ & 20.00 \\
\hline vestment) & 0.00 & -20.00 & -20.00 & -20.00 & -20.00 & -20.00 & -20.00 & -20.00 & -20.00 & -20.00 & -20.00 & -20.00 & -20.00 \\
\hline Aid (\% of total rever & 0.00 & 0.00 & -0.02 & -0.03 & -0.03 & -0.01 & 0.01 & 0.04 & 0.07 & 0.11 & 0.14 & 0.18 & 0.23 \\
\hline 6 of aid) & 0.00 & 0.00 & -0.02 & -0.01 & -0.03 & -0.07 & -0.13 & -0.20 & -0.28 & -0.35 & -0.42 & & -0.55 \\
\hline Domestic deb & 0.00 & 0.00 & 0.00 & 0.00 & -0.01 & -0.02 & -0.04 & -0.05 & -0.07 & -0.09 & -0.11 & -0.13 & -0.15 \\
\hline External debt (\% of GDP) & 0.00 & 0.00 & -0.02 & -0.07 & -0.15 & -0.26 & -0.39 & -0.53 & -0.68 & -0.82 & -0.96 & -1.10 & -1.24 \\
\hline Interest payment on external public debt (\% of $E$ & 0.00 & 0.00 & 0.00 & -0.01 & -0.01 & -0.02 & -0.02 & -0.02 & -0.02 & -0.01 & -0.01 & 0.00 & 0.01 \\
\hline $\begin{array}{l}\text { Degree of ofenness (total trade in } \% \text { of GDP) } \\
\text { Educated labor (in \% of population) }\end{array}$ & $\begin{array}{l}0.00 \\
0.00\end{array}$ & $\begin{array}{l}0.00 \\
0.00\end{array}$ & $\begin{array}{l}0.04 \\
0.00\end{array}$ & $\begin{array}{l}0.06 \\
0.00\end{array}$ & $\begin{array}{l}0.05 \\
0.00\end{array}$ & $\begin{array}{l}0.01 \\
0.00\end{array}$ & $\begin{array}{l}-0.05 \\
0.00\end{array}$ & $\begin{aligned}-0.13 \\
0.00\end{aligned}$ & $\begin{array}{r}-0.21 \\
0.00\end{array}$ & $\begin{array}{r}-0.30 \\
0.00\end{array}$ & $\begin{array}{l}-0.39 \\
0.00\end{array}$ & $\begin{array}{r}-0.50 \\
0.00\end{array}$ & $\begin{array}{l}-0.62 \\
0.00\end{array}$ \\
\hline Educated labor (in \% of population) & 0.00 & & 0.00 & 0.00 & 0.00 & 0.00 & 0.00 & 0.00 & 0.00 & 0.00 & 0.00 & 0.00 & 0.00 \\
\hline
\end{tabular}


Table

Niger: 10 Percent Decrease in Tariff Rate, No Change in Direct or Indirect Tax Rate, 2003-15

\begin{tabular}{|c|c|c|c|c|c|c|c|c|c|c|c|c|c|}
\hline & \multicolumn{13}{|c|}{ Years } \\
\hline & 2003 & 2004 & 2005 & 2006 & 2007 & 2008 & 2009 & 2010 & 2011 & 2012 & 2013 & 2014 & 2015 \\
\hline \multicolumn{14}{|l|}{ Real Sector (in billions of current CFA francs) } \\
\hline $\begin{array}{l}\text { Total supply of goods and services } \\
\text { Gross domestic product at factor cost }\end{array}$ & $\begin{array}{l}0.00 \\
0.00\end{array}$ & $\begin{array}{l}-4.63 \\
-1.44\end{array}$ & $\begin{array}{l}-5.04 \\
-1.71\end{array}$ & $\begin{array}{l}-4.93 \\
-1.91\end{array}$ & 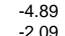 & -4.90 & -4.84 & -4.82 & -4.80 & -4.80 & -4.81 & -5.02 & -5.23 \\
\hline $\begin{array}{l}\text { Gross domestit product at factor cost } \\
\text { mports of goods and NFS (inclusive of tariffs) }\end{array}$ & 0.00 & $\begin{array}{c}-1.44 \\
-1444\end{array}$ & $\begin{array}{r}-1.71 \\
-15.45\end{array}$ & -1.91 & $\begin{array}{ccc}-2.099 \\
0.32\end{array}$ & -2.26 & $\begin{array}{lll}-2.23 \\
-1.23\end{array}$ & $\begin{array}{ccc}-2.22 \\
0.140\end{array}$ & $\begin{array}{lll}-2.15 \\
-1.98\end{array}$ & 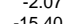 & $\begin{array}{lll}-2.01 \\
-1587\end{array}$ & $=2.23$ & $\begin{array}{l}-2.45 \\
-2.40\end{array}$ \\
\hline Total expenditure on goods and services & 0.00 & $\begin{array}{l}-14.44 \\
-4.64\end{array}$ & $\begin{array}{r}-15.45 \\
-5.04\end{array}$ & $\begin{array}{l}-14.93 \\
-4.93\end{array}$ & $\begin{array}{l}-14.35 \\
-4.88\end{array}$ & $\begin{array}{r}-14.10 \\
-4.89\end{array}$ & $\begin{array}{l}-14.20 \\
-4.84 \\
-\end{array}$ & $\begin{array}{l}-14.48 \\
-4.82\end{array}$ & $\begin{array}{r}-14.08 \\
-4.80\end{array}$ & $\begin{array}{r}-15.40 \\
-4.79\end{array}$ & $\begin{array}{r}-15.81 \\
-4.82\end{array}$ & $\begin{array}{r}-16.20 \\
-502\end{array}$ & $\begin{array}{r}-16.53 \\
-5.24\end{array}$ \\
\hline Total consumption & 0.00 & -4.88 & -4.07 & -3.76 & -3.62 & -3.56 & -3.46 & -3.39 & -3.32 & -3.25 & -3.21 & -3.38 & $\begin{array}{l}-3.24 \\
-3.58\end{array}$ \\
\hline Private consumption & 0.00 & -5.02 & -4.03 & -3.66 & -3.49 & -3.41 & -3.32 & -3.24 & -3.18 & -3.12 & -3.09 & -3.26 & -3.46 \\
\hline Public spending on goods and services & 0.00 & -4.15 & -4.30 & -4.31 & -4.33 & -4.37 & -4.27 & -4.17 & -4.06 & -3.93 & -3.87 & -4.05 & -4.25 \\
\hline Total investment & 0.00 & -6.63 & -18.32 & -18.32 & -17.53 & -16.82 & -16.12 & -15.50 & -14.88 & -14.34 & -13.83 & -13.41 & -12.81 \\
\hline Private investment & 0.00 & -6.23 & -5.99 & -6.68 & -7.17 & -7.54 & -7.77 & -7.92 & -8.00 & -8.03 & -8.03 & -8.15 & -8.23 \\
\hline Public investment & 0.00 & -7.18 & -38.26 & -38.33 & -37.73 & -37.32 & -37.10 & -37.31 & -37.77 & -38.85 & -40.58 & -43.10 & -46.30 \\
\hline Exports of goods and NFS & 0.00 & -1.95 & -3.92 & -5.49 & -6.77 & -7.87 & -8.88 & -9.87 & -10.87 & -11.90 & -12.97 & -13.97 & -14.95 \\
\hline Gross domestic product at market prices & 0.00 & -4.14 & -4.29 & -4.31 & -4.33 & -4.38 & -4.27 & -4.18 & -4.07 & -3.95 & -3.87 & -4.05 & -4.24 \\
\hline Disposable income & 0.00 & -1.78 & -2.18 & -2.51 & -2.81 & -3.09 & -3.17 & -3.24 & -3.26 & -3.25 & -3.26 & -3.54 & -3.81 \\
\hline \multicolumn{14}{|l|}{ Poverty rate } \\
\hline Ravallion's (2004) adjusted elasticity (Gini = 50.5) & 0.00 & -1.02 & -1.55 & -1.83 & -1.95 & -1.95 & -1.88 & -1.77 & -1.63 & -1.48 & -1.32 & -1.13 & -0.91 \\
\hline $\begin{array}{l}\text { Consumption per capita growth elasticity of }-0.5 \\
\text { Consumption per contatarowth elasticity of }-1.0\end{array}$ & 0.00 & -0.45 & $\begin{array}{r}-0.69 \\
1.37\end{array}$ & -0.82 & -0.87 & -0.88 & -0.85 & $\begin{array}{r}-0.81 \\
-158\end{array}$ & $\begin{array}{l}-0.75 \\
-1.5\end{array}$ & -0.68 & -0.61 & -0.52 & -0.43 \\
\hline $\begin{array}{l}\text { Consumption per capatitg growth elasticitit of -1.0. } \\
\text { Consumption per capita growth elasticity of }-1.5\end{array}$ & $\begin{array}{l}0.00 \\
0.00\end{array}$ & $\begin{array}{l}-0.90 \\
-1.35\end{array}$ & $\begin{array}{l}-1.37 \\
-2.05\end{array}$ & $\begin{array}{l}-1.62 \\
-2.42\end{array}$ & $\begin{array}{l}-1.73 \\
-2.57\end{array}$ & $\begin{array}{l}-1.73 \\
-2.56\end{array}$ & $\begin{array}{l}-1.67 \\
-2.46\end{array}$ & $\begin{array}{l}-1.58 \\
-2.31\end{array}$ & $\begin{array}{l}-1.45 \\
-2.12\end{array}$ & $\begin{array}{l}-1.32 \\
-1.92\end{array}$ & $\begin{array}{l}-1.18 \\
-1.70\end{array}$ & $\begin{array}{l}-1.01 \\
-1.45\end{array}$ & -0.82 \\
\hline \multirow{2}{*}{\multicolumn{14}{|c|}{ External Sector (\% of GDP) }} \\
\hline Current account ${ }^{\circ}$ & 0.00 & 0.61 & 0.52 & 0.05 & -0.28 & -0.51 & -0.60 & -0.68 & -0.71 & -0.71 & -0.74 & -0.82 & \\
\hline Trade balance & 0.00 & 0.91 & 0.86 & 0.39 & 0.06 & -0.18 & -0.28 & -0.37 & -0.41 & -0.43 & -0.46 & -0.54 & -0.61 \\
\hline Exports of goods and NFS & 0.00 & 0.35 & 0.06 & -0.19 & -0.38 & -0.54 & -0.69 & -0.84 & -0.98 & -1.13 & -1.28 & -1.38 & 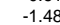 \\
\hline Imports of goods and NFS & 0.00 & -0.56 & -0.80 & -0.58 & -0.44 & -0.36 & -0.41 & -0.47 & -0.57 & -0.70 & -0.81 & -0.84 & -0.86 \\
\hline Private unrequited transfers & 0.00 & 0.03 & 0.03 & 0.03 & 0.03 & 0.03 & 0.03 & 0.03 & 0.03 & 0.03 & 0.03 & 0.03 & 0.03 \\
\hline Income (net) & 0.00 & -0.02 & -0.06 & -0.07 & -0.08 & -0.09 & -0.10 & -0.10 & -0.10 & -0.10 & -0.11 & -0.11 & -0.11 \\
\hline Public & 0.00 & -0.04 & -0.08 & -0.09 & -0.10 & -0.11 & -0.11 & -0.12 & -0.12 & -0.12 & -0.12 & -0.12 & -0.13 \\
\hline $\begin{array}{r}\text { Private } \\
\text { Pid }\end{array}$ & 0.00 & 0.02 & 0.02 & 0.02 & 0.02 & 0.02 & 0.02 & 0.02 & 0.02 & 0.02 & 0.01 & 0.01 & 0.02 \\
\hline $\begin{array}{l}\text { Ald total } \\
\text { OO }\end{array}$ & 0.00 & 0.00 & 0.00 & 0.00 & 0.00 & 0.00 & 0.00 & 0.00 & 0.00 & 0.00 & 0.00 & 0.00 & $0.00>>>2>0$ \\
\hline Other current account flows (net) & 0.00 & -0.31 & -0.31 & -0.30 & -0.29 & -0.28 & -0.26 & -0.24 & -0.22 & -0.21 & -0.19 & -0.20 & $-0.20>>20,0$ \\
\hline Capital account & 0.00 & 2.22 & 0.99 & 0.83 & 0.72 & 0.64 & 0.56 & 0.50 & 0.45 & 0.42 & 0.38 & 0.35 & 0.33 \\
\hline $\begin{array}{l}\text { Private borrowing } \\
\text { Public borrowing }\end{array}$ & 0.00 & 0.01 & 0.01 & 0.01 & 0.01 & 0.01 & 0.01 & 0.01 & 0.01 & 0.01 & 0.01 & 0.01 & 0.01 \\
\hline $\begin{array}{l}\text { Public borrowing } \\
\text { Errors and omissions }\end{array}$ & $\begin{array}{l}0.00 \\
0.00\end{array}$ & 0.02 & 0.01 & $\begin{array}{l}0.81 \\
0.01\end{array}$ & 0.01 & $\begin{array}{l}0.02 \\
0.01\end{array}$ & $\begin{array}{l}0.01 \\
0.01\end{array}$ & $\begin{array}{l}0.01 \\
0.48\end{array}$ & $\begin{array}{l}0.44 \\
0.00\end{array}$ & 0.00 & 0.00 & $\begin{array}{l}0.33 \\
0.00\end{array}$ & $\begin{array}{l}0.32 \\
0.00\end{array}$ \\
\hline \multicolumn{14}{|l|}{$\begin{array}{l}\text { Government Sector (\% of GDP) } \\
\text { Total revenue (including grantss }\end{array}$} \\
\hline Total revenue (including grants) & 0.00 & -2.32 & -2.08 & -1.77 & -1.51 & -1.28 & -1.09 & -0.93 & -0.80 & -0.68 & -0.59 & -0.48 & -0.40 \\
\hline Domestic taxes & 0.00 & 0.31 & 0.54 & 0.73 & 0.89 & 1.04 & 1.16 & 1.27 & 1.36 & 1.45 & 1.53 & 1.60 & 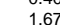 \\
\hline Direct taxes & 0.00 & 0.22 & 0.36 & 0.50 & 0.62 & 0.73 & 0.83 & 0.92 & 1.01 & 1.09 & 1.17 & 1.23 & 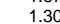 \\
\hline Indirect taxes & 0.00 & 0.09 & 0.17 & 0.23 & 0.28 & 0.31 & 0.33 & 0.34 & 0.35 & 0.36 & 0.36 & 0.37 & 0.37 \\
\hline Indirect taxes on imports & 0.00 & -2.64 & -2.61 & -2.50 & -2.41 & -2.32 & -2.25 & -2.20 & -2.16 & -2.13 & -2.11 & -2.08 & -2.06 \\
\hline Foreign aid (grants) & 0.00 & 0.00 & 0.00 & 0.00 & 0.00 & 0.00 & 0.00 & 0.00 & 0.00 & 0.00 & 0.00 & 0.00 & 0.00 \\
\hline Total expenditure & 0.00 & -0.15 & -1.12 & -0.99 & -0.84 & -0.70 & -0.59 & -0.49 & -0.40 & -0.33 & -0.27 & -0.20 & -0.13 \\
\hline $\begin{array}{l}\text { Spending on goodds and services } \\
\text { Wagaes and salaries }\end{array}$ & $\begin{array}{l}0.00 \\
0.00\end{array}$ & $\begin{array}{r}0.00 \\
-0.08\end{array}$ & $\begin{array}{r}0.00 \\
-0.06\end{array}$ & 0.00 & 0.00 & 0.00 & 0.00 & 0.00 & $\begin{array}{r}0.00 \\
-0.05\end{array}$ & $\begin{array}{r}0.00 \\
-0.05\end{array}$ & $\begin{array}{r}0.00 \\
-0.04\end{array}$ & 0.00 & 0.00 \\
\hline $\begin{array}{l}\text { Wages and salaries } \\
\text { Investment }\end{array}$ & $\begin{array}{l}0.00 \\
0.00\end{array}$ & $\begin{array}{l}-0.08 \\
-0.12\end{array}$ & $\begin{array}{l}-0.06 \\
-1.13\end{array}$ & $\begin{array}{l}-0.06 \\
-1.02\end{array}$ & 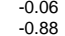 & $\begin{array}{l}-0.06 \\
-0.76\end{array}$ & $\begin{array}{l}-0.06 \\
-0.65\end{array}$ & $\begin{array}{l}-0.05 \\
-0.56\end{array}$ & $\begin{array}{l}-0.05 \\
-0.48\end{array}$ & $\begin{array}{l}-0.05 \\
-0.41\end{array}$ & $\begin{array}{l}-0.04 \\
-0.35\end{array}$ & $\begin{array}{l}-0.03 \\
-0.29\end{array}$ & $\begin{array}{l}-0.02 \\
-0.24 \\
-\end{array}$ \\
\hline $\begin{array}{l}\text { Invesement } \\
\text { Interest payments }\end{array}$ & $\begin{array}{l}0.00 \\
0.00\end{array}$ & $\begin{array}{l}-0.12 \\
0.05\end{array}$ & $\begin{array}{r}-1.13 \\
0.08\end{array}$ & $\begin{aligned}-1.02 \\
0.10\end{aligned}$ & $\begin{array}{l}-0.88 \\
0.11\end{array}$ & $\begin{array}{l}-0.76 \\
0.11\end{array}$ & $\begin{array}{l}-0.65 \\
0.12\end{array}$ & $\begin{array}{r}-0.56 \\
0.12\end{array}$ & $\begin{array}{r}-0.48 \\
0.12\end{array}$ & $\begin{array}{r}-0.41 \\
0.12\end{array}$ & $\begin{array}{r}-0.35 \\
0.12\end{array}$ & $\begin{array}{l}-0.29 \\
0.13\end{array}$ & 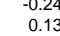 \\
\hline Domestic debt & 0.00 & 0.00 & 0.00 & 0.00 & 0.00 & 0.00 & 0.00 & 0.00 & 0.00 & 0.00 & 0.00 & 0.00 & 0.00 \\
\hline Foreign debt & 0.00 & 0.04 & 0.08 & 0.09 & 0.10 & 0.11 & 0.11 & 0.12 & 0.12 & 0.12 & 0.12 & 0.12 & $0.13>>>>3$ \\
\hline Overall fiscal balance & 0.00 & -2.19 & -0.97 & -0.81 & -0.71 & -0.62 & -0.55 & -0.48 & -0.44 & -0.40 & -0.37 & -0.33 & -0.32 \\
\hline Total financing & 0.00 & 2.19 & 0.97 & 0.81 & 0.71 & 0.62 & 0.55 & 0.48 & 0.44 & 0.40 & 0.37 & 0.33 & 0.32 \\
\hline Foreign financing & 0.00 & 2.19 & 0.97 & 0.81 & 0.71 & 0.62 & 0.55 & 0.48 & 0.44 & 0.40 & 0.37 & 0.33 & 0.32 \\
\hline Domestic borrowing & 0.00 & 0.00 & 0.00 & 0.00 & 0.00 & 0.00 & 0.00 & 0.00 & 0.00 & 0.00 & 0.00 & 0.00 & 0.00 \\
\hline \multicolumn{14}{|l|}{ Prices and Real Ex } \\
\hline GDP at factor cost $d$ & 0.00 & -1.44 & -0.28 & -0.21 & -0.16 & -0.13 & 0.10 & 0.12 & 0.20 & 0.22 & 0.21 & -0.07 & -0.06 \\
\hline Composite good price (after indirect taxes, \% change) & 0.00 & -6.24 & 0.36 & 0.01 & 0.03 & 0.08 & 0.19 & 0.23 & 0.25 & 0.27 & 0.26 & 0.11 & 0.12 \\
\hline Real exchange rate (\% change) & 0.00 & 6.24 & -0.36 & -0.01 & -0.03 & -0.08 & -0.19 & -0.23 & -0.25 & -0.27 & -0.26 & -0.11 & -0.12 \\
\hline Memorandum items & & & & & & & & & & & & & \\
\hline Real GDP per capita at factor cost ( $\%$ change) & 0.00 & 0.00 & 0.01 & 0.01 & -0.02 & -0.05 & -0.08 & -0.11 & -0.13 & -0.15 & -0.16 & -0.17 & -0.17 \\
\hline Real GDP per capita at market prices (\% change) & 0.00 & 1.77 & -0.52 & -0.03 & -0.06 & -0.13 & -0.07 & -0.13 & -0.13 & -0.15 & -0.17 & -0.31 & -0.33 \\
\hline Real disposable income per capita (\% change) & 0.00 & 4.40 & -0.78 & -0.36 & -0.35 & -0.38 & -0.27 & -0.31 & -0.27 & -0.27 & -0.27 & -0.41 & -0.41 \\
\hline Private savings rate $(\%$ of $\mathrm{C}$ & 0.00 & 0.23 & 0.21 & 0.18 & 0.15 & 0.13 & 0.11 & 0.09 & 0.08 & 0.07 & 0.06 & 0.05 & $0.04+454$ \\
\hline $\begin{array}{l}\text { Real private consumption } p \\
\text { Privat }\end{array}$ & 0.00 & 1.43 & 0.76 & 0.42 & 0.19 & 0.03 & 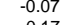 & -0.14 & & -0.20 & -0.23 & -0.28 & -0.32 \\
\hline $\begin{array}{l}\text { Private investment (\% of } \\
\text { Private investment } \% \text { of }\end{array}$ & 0.00 & -0.11 & $\begin{array}{r}-0.09 \\
933\end{array}$ & -0.12 & -0.15 & -0.16 & $\begin{array}{l}-0.17 \\
712\end{array}$ & -0.18 & $\begin{array}{r}-0.18 \\
6.22\end{array}$ & $\begin{array}{r}-0.19 \\
586\end{array}$ & -0.18 & -0.17 & -0.16 \\
\hline $\begin{array}{l}\text { Private investment }(\% \text { of total investment) } \\
\text { Public investment } \% \text { of total public expenditure) }\end{array}$ & $\begin{array}{l}0.00 \\
0.00\end{array}$ & $\begin{array}{r}0.25 \\
-0.40\end{array}$ & $\begin{array}{r}9.33 \\
-4.56\end{array}$ & $\begin{array}{l}9.01 \\
-4.21\end{array}$ & $\begin{array}{r}8.30 \\
-3.74\end{array}$ & $\begin{array}{r}7.68 \\
-3.30\end{array}$ & 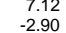 & $\begin{array}{r}6.66 \\
-2.55 \\
\end{array}$ & $\begin{array}{r}6.22 \\
-2.23\end{array}$ & $\begin{array}{r}5.86 \\
-1.96\end{array}$ & $\begin{array}{r}5.53 \\
-1.71\end{array}$ & $\begin{array}{r}5.16 \\
-1.46\end{array}$ & $\begin{array}{r}4.62 \\
-1.19\end{array}$ \\
\hline & 0.00 & 0.00 & $\begin{array}{r}-4.56 \\
0.00\end{array}$ & 0.00 & 0.00 & $\begin{array}{l}-3.30 \\
0.00\end{array}$ & 0.00 & $\begin{array}{c}-2.05 \\
0.00\end{array}$ & $\begin{array}{l}-2.23 \\
0.00\end{array}$ & $\begin{array}{r}-1.96 \\
0.00\end{array}$ & $\begin{array}{r}-1.11 \\
0.00\end{array}$ & $\begin{array}{r}-1.46 \\
0.00\end{array}$ & $\begin{array}{l}-1.19 \\
0.00\end{array}$ \\
\hline 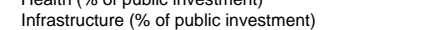 & 0.00 & 0.00 & 0.00 & 0.00 & 0.00 & 0.00 & 0.00 & 0.00 & 0.00 & 0.00 & 0.00 & 0.00 & 0.00 \\
\hline Education (\% of public investment) & 0.00 & 0.00 & 0.00 & 0.00 & 0.00 & 0.00 & 0.00 & 0.00 & 0.00 & 0.00 & 0.00 & 0.00 & 0.00 \\
\hline Other (\% of public investment) & 0.00 & 0.00 & 0.00 & 0.00 & 0.00 & 0.00 & 0.00 & 0.00 & 0.00 & 0.00 & 0.00 & 0.00 & 0.00 \\
\hline Aid (\% of total revenue) & 0.00 & 7.09 & 6.47 & 5.66 & 4.93 & 4.27 & 3.72 & 3.21 & 2.79 & 2.43 & 2.10 & 1.75 & 1.44 \\
\hline Total public investment (\% of aid) & 0.00 & -1.09 & -10.63 & -9.57 & -8.26 & -7.10 & -6.08 & -5.22 & -4.46 & -3.83 & -3.28 & -2.76 & -2.21 \\
\hline $\begin{array}{l}\text { Domestic debt }(\% \text { of GD } \\
\text { Fyternaldeht } \% \text { f } G D E\end{array}$ & 0.00 & 0.31 & 0.31 & 0.30 & 0.29 & 0.28 & 0.26 & 0.23 & 0.21 & $\begin{array}{r}0.19 \\
795\end{array}$ & 0.17 & 0.19 & 0.21 \\
\hline $\begin{array}{l}\text { Exterral debt (\% of GD) } \\
\text { Interest payment on external public debt (\% of exports) }\end{array}$ & $\begin{array}{l}0.00 \\
0.00\end{array}$ & $\begin{array}{l}5.56 \\
0.13\end{array}$ & $\begin{array}{l}6.47 \\
0.49\end{array}$ & $\begin{array}{l}7.03 \\
0.70\end{array}$ & $\begin{array}{l}7.45 \\
0.87\end{array}$ & $\begin{array}{l}7.77 \\
1.03\end{array}$ & $\begin{array}{l}7.88 \\
1.17\end{array}$ & $\begin{array}{l}1.94 \\
1.31\end{array}$ & $\begin{array}{r}7.96 \\
1.45\end{array}$ & $\begin{array}{r}7.95 \\
1.58\end{array}$ & $\begin{array}{l}7.94 \\
1.72\end{array}$ & $\begin{array}{l}8.11 \\
1.85\end{array}$ & $\begin{array}{l}8.28 \\
1.96\end{array}$ \\
\hline $\begin{array}{l}\text { Degree of openness (total trade in \% of GDP) } \\
\text { D. }\end{array}$ & 0.00 & -2.85 & $\begin{array}{r}0.49 \\
-3.35\end{array}$ & $\begin{array}{l}.0 .27 \\
-3.27\end{array}$ & $\begin{array}{c}.0 .23 \\
-3.23\end{array}$ & -3.22 & $\begin{array}{l}-1.36 \\
-3.36\end{array}$ & -3.51 & $\begin{array}{r}1.45 \\
-3.72\end{array}$ & $\begin{array}{r}1.00 \\
-3.97\end{array}$ & -4.20 & -4.30 & $\begin{array}{l}1.96 \\
-4.40\end{array}$ \\
\hline Educated labor (in $\%$ of population) & 0.00 & 0.00 & 0.00 & 0.00 & 0.00 & 0.00 & 0.00 & 0.00 & 0.00 & 0.00 & 0.00 & 0.00 & 0.00 \\
\hline
\end{tabular}


Table 7

Niger: 10 Percent Decrease in Tariff Rate, Increase in Direct Tax Rate to 5.2 Percent, 2003-15

\begin{tabular}{|c|c|c|c|c|c|c|c|c|c|c|c|c|c|}
\hline & \multicolumn{13}{|c|}{ Years } \\
\hline & 2003 & 2004 & 2005 & 2006 & 2007 & 2008 & 2009 & 2010 & 2011 & 2012 & 2013 & 2014 & 2015 \\
\hline \multicolumn{14}{|l|}{ Real Sector (in billions of current CFA francs) } \\
\hline $\begin{array}{l}\text { Total supply of goods and services } \\
\text { Gross domestic product at factor cost }\end{array}$ & $\begin{array}{l}0.00 \\
0.00\end{array}$ & $\begin{array}{l}-4.41 \\
-0.21\end{array}$ & $\begin{array}{l}-4.50 \\
-0.53\end{array}$ & & -4.66 & -4.66 & -4.66 & -4.67 & -4.63 & -4.62 & -4.65 & -4.85 & -5.07 \\
\hline $\begin{array}{l}\text { Gross domestic product at atctor cost } \\
\text { Imports of goods and NFS (inclusive of tariffs) }\end{array}$ & $\begin{array}{l}0.00 \\
0.00\end{array}$ & $\begin{array}{r}-0.21 \\
-1731\end{array}$ & $\begin{array}{r}-0.53 \\
-16.92\end{array}$ & $\begin{array}{r}-0.80 \\
-16.78\end{array}$ & -1.03 & -1.04 & $=1.01$ & -0.94 & $\begin{array}{lll}-0.16 \\
-0.21\end{array}$ & $=0.00$ & $=0.50$ & $=0.6 \%$ & -0.84 \\
\hline Total expenditure on goods and services & 0.00 & -4.41 & $\begin{array}{r}-16.92 \\
-4.49\end{array}$ & $\begin{array}{l}-10.18 \\
-4.56\end{array}$ & $\begin{array}{l}-1.64 \\
-4.64\end{array}$ & $\begin{array}{r}-17.28 \\
-4.66\end{array}$ & $\begin{array}{r}-17.83 \\
-4.65\end{array}$ & $\begin{array}{l}-1.50 \\
-4.66\end{array}$ & $\begin{array}{r}-19.31 \\
-4.63\end{array}$ & $\begin{aligned}-20.22 \\
-4.63\end{aligned}$ & $\begin{array}{l}-21.62 \\
-4.64\end{array}$ & $\begin{array}{r}-21.62 \\
-4.84\end{array}$ & $\begin{array}{l}-22.24 \\
-5.09\end{array}$ \\
\hline Total consumption & 0.00 & -4.56 & -4.32 & -4.19 & -4.15 & -4.05 & -3.95 & -3.86 & -3.73 & -3.60 & -3.49 & -3.60 & $\begin{array}{l}-5.09 \\
-3.76\end{array}$ \\
\hline Private consumption & 0.00 & -4.80 & -4.49 & -4.31 & -4.24 & -4.14 & -4.03 & -3.95 & -3.83 & -3.71 & -3.61 & -3.71 & -3.87 \\
\hline Public spending on goods and services & 0.00 & -3.19 & -3.41 & -3.55 & -3.66 & -3.60 & -3.49 & -3.37 & -3.18 & -2.99 & -2.84 & -2.97 & -3.15 \\
\hline Total investment & 0.00 & -5.73 & -5.43 & -4.12 & -2.44 & -0.56 & 1.47 & 3.64 & 5.98 & 8.38 & 10.91 & 13.51 & 16.50 \\
\hline Private investment & 0.00 & -5.31 & -5.29 & -5.26 & -5.04 & -4.63 & -4.11 & -3.51 & -2.80 & -2.04 & -1.22 & -0.52 & 0.21 \\
\hline $\begin{array}{l}\text { Public investment } \\
\text { Exports of goods and NFS }\end{array}$ & $\begin{array}{l}0.00 \\
0.00\end{array}$ & $\begin{array}{l}-6.31 \\
-2.72\end{array}$ & $\begin{array}{l}-5.65 \\
-5.08\end{array}$ & $\begin{array}{l}-2.17 \\
-7.10\end{array}$ & $\begin{array}{r}2.63 \\
-8.89\end{array}$ & $\begin{array}{r}8.42 \\
-10.57\end{array}$ & $\begin{array}{r}15.46 \\
-2123\end{array}$ & $\begin{array}{r}24.22 \\
-13.83\end{array}$ & $\begin{array}{r}35.19 \\
-.45\end{array}$ & $\begin{array}{r}48.79 \\
-17.16\end{array}$ & $\begin{array}{r}66.84 \\
-1889\end{array}$ & $\begin{array}{r}92.61 \\
-20.57\end{array}$ & $\begin{array}{r}135.59 \\
-22.22\end{array}$ \\
\hline Gross domestic product at market prices & & & -3.41 & -3.55 & -368 & -10.56 & $\begin{array}{r}-12.21 \\
-350\end{array}$ & -338 & -15.41 & -17.10 & -10.89 & -20.51 & $-2<.24$ \\
\hline $\begin{array}{l}\text { Gross domesstic product at market prices } \\
\text { Disposable income }\end{array}$ & $\begin{array}{l}0.00 \\
0.00\end{array}$ & $\begin{array}{l}-3.18 \\
-3.29\end{array}$ & $\begin{array}{r}-3.41 \\
-3.74\end{array}$ & $\begin{array}{l}-3.55 \\
-4.12 \\
\end{array}$ & $\begin{array}{l}-3.68 \\
-4.46\end{array}$ & $\begin{array}{l}-3.60 \\
-4.56\end{array}$ & $\begin{array}{r}-3.50 \\
-4.63\end{array}$ & $\begin{array}{l}-3.38 \\
-4.66\end{array}$ & $\begin{array}{l}-3.17 \\
-4.56\end{array}$ & $\begin{array}{r}-2.98 \\
-4.48\end{array}$ & $\begin{array}{l}-2.86 \\
-4.44\end{array}$ & $\begin{array}{l}-2.98 \\
-4.65\end{array}$ & $\begin{array}{l}-3.13 \\
-4.87\end{array}$ \\
\hline \multicolumn{14}{|l|}{ Poverty rate } \\
\hline Ravallion's (2004) adjusted elasticity (Gini = 50.5) & 0.00 & -0.49 & -0.73 & -0.79 & -0.72 & -0.58 & -0.38 & -0.16 & 0.07 & 0.31 & 0.56 & 0.84 & 1.14 \\
\hline 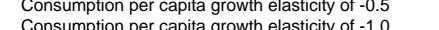 & 0.00 & -0.22 & -0.32 & -0.35 & -0.32 & -0.26 & -0.17 & -0.07 & 0.03 & 0.14 & 0.26 & 0.38 & 0.53 \\
\hline $\begin{array}{l}\text { Consumption per capatitg growth elasticitit of -1.0. } \\
\text { Consumption per capita growth elasticity of }-1.5\end{array}$ & $\begin{array}{l}0.00 \\
0.00\end{array}$ & $\begin{array}{l}-0.43 \\
-0.65\end{array}$ & $\begin{array}{l}-0.65 \\
-0.97\end{array}$ & $\begin{array}{l}-0.70 \\
-1.04\end{array}$ & $\begin{array}{l}-0.64 \\
-0.95\end{array}$ & $\begin{array}{l}-0.51 \\
-0.76\end{array}$ & $\begin{array}{l}-0.34 \\
-0.50\end{array}$ & $\begin{array}{l}-0.14 \\
-0.21\end{array}$ & 0.07 & 0.28 & $\begin{array}{l}0.50 \\
0.73\end{array}$ & $\begin{array}{r}0.75 \\
109\end{array}$ & 1.02 \\
\hline \multirow{2}{*}{\multicolumn{14}{|c|}{ External Sector (\% of GDP) }} \\
\hline Current account ${ }^{\circ}$ & 0.00 & 1.45 & 0.91 & 0.51 & 0.22 & 0.07 & & -0.09 & & -0.10 & -0.14 & -0.24 & \\
\hline Trade balance & 0.00 & 1.68 & 1.15 & 0.73 & 0.43 & 0.26 & 0.13 & 0.05 & 0.00 & -0.03 & -0.09 & -0.21 & -0.32 \\
\hline Exports of goods and NFS & 0.00 & 0.07 & -0.27 & -0.56 & -0.81 & -1.06 & -1.30 & -1.53 & -1.76 & -1.99 & -2.22 & -2.41 & -2.60 \\
\hline Imports of goods and NFS & 0.00 & -1.60 & -1.41 & -1.29 & -1.25 & -1.32 & -1.43 & -1.57 & -1.76 & -1.96 & -2.13 & -2.21 & -2.28 \\
\hline Private unrequited transfers & 0.00 & 0.02 & 0.02 & 0.03 & 0.03 & 0.02 & 0.02 & 0.02 & 0.02 & 0.02 & 0.02 & 0.02 & 0.02 \\
\hline Income (net) & 0.00 & -0.02 & -0.01 & -0.01 & 0.00 & 0.01 & 0.02 & 0.04 & 0.05 & 0.06 & 0.08 & 0.09 & 0.10 \\
\hline Public & 0.00 & -0.03 & -0.03 & -0.02 & -0.02 & 0.00 & 0.01 & 0.02 & 0.04 & 0.05 & 0.07 & 0.08 & 0.09 \\
\hline $\begin{array}{r}\text { Private } \\
\text { Pid }\end{array}$ & 0.00 & 0.02 & 0.02 & 0.02 & 0.02 & 0.02 & 0.01 & 0.01 & 0.01 & 0.01 & 0.01 & 0.01 & 0.01 \\
\hline $\begin{array}{l}\text { AAd, total } \\
\text { ON }\end{array}$ & & 0.00 & 0.00 & 0.00 & 0.00 & 0.00 & 0.00 & 0.00 & 0.00 & 0.00 & 0.00 & 0.00 & 0.00 \\
\hline Other current account flows (net) & 0.00 & -0.23 & -0.24 & -0.24 & -0.24 & -0.22 & -0.21 & -0.19 & -0.17 & -0.15 & -0.14 & -0.14 & -0.14 \\
\hline Capital account & 0.00 & -0.22 & -0.40 & -0.52 & -0.61 & -0.69 & -0.76 & -0.82 & -0.87 & -0.91 & -0.95 & -0.99 & -1.01 \\
\hline 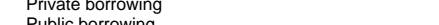 & 0.00 & $0.012>012$ & 0.01 & 0.01 & 0.01 & 0.01 & 0.01 & 0.01 & 0.01 & 0.01 & 0.01 & 0.01 & 0.01 \\
\hline $\begin{array}{l}\text { Public borrowing } \\
\text { Errors and omissions }\end{array}$ & $\begin{array}{l}0.00 \\
0.00\end{array}$ & $\begin{array}{c}-0.23 \\
0.00\end{array}$ & $\begin{array}{r}-0.40 \\
0.00\end{array}$ & $\begin{array}{l}-0.52 \\
-0.01\end{array}$ & -0.61 & -0.69 & -0.76 & -0.82 & -0.87 & -0.91 & -0.94 & -0.98 & -1.01 \\
\hline Errors and omissions & 0.00 & & 0.00 & -0.01 & -0.01 & -0.01 & -0.01 & -0.01 & -0.01 & -0.01 & -0.01 & -0.01 & -0.01 \\
\hline \multicolumn{14}{|l|}{$\begin{array}{l}\text { Government Sector (\% of GDP) } \\
\text { Total revenue (including grants) }\end{array}$} \\
\hline & 0.00 & $\begin{array}{l}0.06 \\
2.81\end{array}$ & $\begin{array}{l}0.29 \\
296\end{array}$ & 0.53 & $\begin{array}{l}0.14 \\
3.23\end{array}$ & $\begin{array}{l}0.93 \\
3.35\end{array}$ & 1.10 & 1.24 & $\begin{array}{l}1.36 \\
364\end{array}$ & $\begin{array}{l}1.46 \\
3.72\end{array}$ & 1.55 & $\begin{array}{l}1.64 \\
3.87\end{array}$ & 1.72 \\
\hline $\begin{array}{l}\text { Domestic taxes } \\
\text { Direct taxes }\end{array}$ & $\begin{array}{l}0.00 \\
0.00\end{array}$ & 2.04 & 298 & ${ }_{312}^{.11}$ & 324 & $\begin{array}{l}3.35 \\
3.35\end{array}$ & 3.46 & 3.55 & 3.64 & 3.72 & 3.80 & 3.87 & 3.93 \\
\hline $\begin{array}{l}\text { Direct taxes } \\
\text { Indirect taxes }\end{array}$ & $\begin{array}{l}0.00 \\
0.00-3-2\end{array}$ & -0.03 & $\begin{array}{r}-.90 \\
-0.02\end{array}$ & -0.01 & 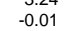 & $\begin{array}{l}3.35 \\
0.00\end{array}$ & $\begin{array}{l}3.46 \\
0.00\end{array}$ & $\begin{array}{l}3.55 \\
0.00\end{array}$ & $\begin{array}{l}3.64 \\
0.00\end{array}$ & $\begin{array}{l}3.72 \\
0.00\end{array}$ & $\begin{array}{l}3.80 \\
0.00\end{array}$ & $\begin{array}{l}3.87 \\
0.00\end{array}$ & $\begin{array}{l}3.93 \\
0.00\end{array}$ \\
\hline Indirect taxes on imports & 0.00 & -2.74 & -2.68 & -2.58 & -2.49 & -2.42 & -2.36 & -2.31 & -2.28 & -2.27 & -2.25 & -2.23 & -2.21 \\
\hline Foreign aid (grants) & 0.00 & 0.00 & 0.00 & 0.00 & 0.00 & 0.00 & 0.00 & 0.00 & 0.00 & 0.00 & 0.00 & 0.00 & 0.00 \\
\hline Total expenditure & 0.00 & -0.16 & -0.11 & 0.00 & 0.13 & 0.23 & 0.33 & 0.41 & 0.48 & 0.54 & 0.59 & 0.65 & 0.71 \\
\hline $\begin{array}{l}\text { Spending on goods and services } \\
\text { Wages and salaries }\end{array}$ & $\begin{array}{l}0.00 \\
0.00\end{array}$ & $\begin{array}{r}0.00 \\
-0.08\end{array}$ & $\begin{array}{r}0.00 \\
-0.07-25\end{array}$ & 0.00 & 0.00 & $\begin{array}{r}0.00 \\
-0.05\end{array}$ & 0.00 & 0.00 & $\begin{array}{r}0.00 \\
-0.02\end{array}$ & 0.00 & 0.00 & 0.00 & 0.00 \\
\hline $\begin{array}{l}\text { Wages and salaries } \\
\text { Investment }\end{array}$ & $\begin{array}{l}0.00 \\
0.00\end{array}$ & 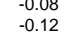 & $\begin{array}{l}-0.07 \\
-0.07\end{array}$ & $\begin{array}{l}-0.06 \\
0.04\end{array}$ & $\begin{array}{l}-0.05 \\
0.17\end{array}$ & $\begin{array}{r}-0.05 \\
0.27\end{array}$ & $\begin{array}{r}-0.04 \\
0.37\end{array}$ & $\begin{array}{r}-0.03 \\
0.46\end{array}$ & $\begin{array}{r}-0.02 \\
0.54\end{array}$ & $\begin{array}{r}-0.01 \\
0.60\end{array}$ & $\begin{array}{l}0.00 \\
0.66\end{array}$ & $\begin{array}{l}0.01 \\
0.71\end{array}$ & $\begin{array}{l}0.03 \\
0.77-3-30\end{array}$ \\
\hline $\begin{array}{l}\text { Investment } \\
\text { Interest payments }\end{array}$ & 0.00 & 0.04 & $\begin{array}{l}-0.07 \\
0.03\end{array}$ & $\begin{array}{l}0.04 \\
0.03\end{array}$ & 0.02 & 0.01 & $\begin{array}{r}0.07 \\
-0.01\end{array}$ & $\begin{array}{l}0.46 \\
-0.02\end{array}$ & $\begin{array}{r}0.54 \\
-0.04\end{array}$ & $\begin{array}{r}0.00 \\
-0.05\end{array}$ & $\begin{array}{l}0.06 \\
-0.07\end{array}$ & $\begin{array}{r}0.11 \\
-0.08\end{array}$ & $\begin{array}{r}0.77 \\
-0.09\end{array}$ \\
\hline Domestic debt & 0.00 & 0.00 & 0.00 & 0.00 & $\begin{array}{l}0.02 \\
0.00\end{array}$ & $\begin{array}{l}0.01 \\
0.00\end{array}$ & $\begin{array}{l}-0.01 \\
0.00\end{array}$ & $\begin{array}{c}-0.02 \\
0.00\end{array}$ & $\begin{array}{l}-0.04 \\
0.00\end{array}$ & $\begin{array}{l}-0.05 \\
0.00\end{array}$ & $\begin{array}{r}-0.01 \\
0.00\end{array}$ & $\begin{array}{l}-0.08 \\
0.00\end{array}$ & $\begin{array}{r}-0.09 \\
0.00\end{array}$ \\
\hline Foreign debt & 0.00 & 0.03 & 0.03 & 0.02 & 0.02 & 0.00 & -0.01 & -0.02 & -0.04 & -0.05 & -0.07 & -0.08 & -0.09 \\
\hline Overall fiscal balance & 0.00 & 0.23 & 0.40 & 0.52 & 0.61 & 0.69 & 0.76 & 0.82 & 0.87 & 0.91 & 0.94 & 0.98 & 1.01 \\
\hline Total financing & 0.00 & -0.23 & -0.40 & -0.52 & -0.61 & -0.69 & -0.76 & -0.82 & -0.87 & -0.91 & -0.94 & -0.98 & -1.01 \\
\hline Foreign financing & 0.00 & -0.23 & -0.40 & -0.52 & -0.61 & -0.69 & -0.76 & -0.82 & -0.87 & -0.91 & -0.94 & -0.98 & -1.01 \\
\hline Domestic borrowing & 0.00 & 0.00 & 0.00 & 0.00 & 0.00 & 0.00 & 0.00 & 0.00 & 0.00 & 0.00 & 0.00 & 0.00 & 0.00 \\
\hline \multicolumn{14}{|l|}{ Prices and Real Exch } \\
\hline GDP at factor cost defla & 0.00 & -0.21 & -0.33 & -0.27 & -0.24 & -0.01 & 0.01 & 0.04 & 0.15 & 0.12 & 0.05 & -0.24 & -0.27 \\
\hline Composite good price (after indirect taxes, \% change) & 0.00 & -5.44 & -0.01 & 0.10 & 0.16 & 0.31 & 0.38 & 0.41 & 0.47 & 0.48 & 0.48 & 0.32 & 0.30 \\
\hline Real exchange rate (\% change) & 0.00 & 5.44 & 0.01 & -0.10 & -0.16 & -0.31 & -0.38 & -0.41 & -0.47 & -0.48 & -0.48 & -0.32 & -0.30 \\
\hline \multicolumn{14}{|l|}{ Memorandum items } \\
\hline Real GDP per capita at factor cost ( $\%$ change) & 0.00 & 0.00 & 0.01 & 0.01 & 0.01 & 0.01 & 0.02 & 0.02 & 0.03 & 0.05 & 0.06 & 0.08 & 0.09 \\
\hline Real GDP per capita at market prices (\% change) & 0.00 & 2.01 & -0.24 & -0.25 & -0.29 & -0.22 & -0.28 & -0.28 & -0.24 & -0.27 & -0.34 & -0.46 & -0.46 \\
\hline Real disposable income per capita (\% change) & 0.00 & 2.05 & -0.48 & -0.52 & -0.53 & -0.43 & -0.46 & -0.44 & -0.37 & -0.38 & -0.44 & -0.56 & -0.54 \\
\hline Private savings rate ( & 0.00 & -0.01 & -0.03 & -0.05 & -0.08 & -0.09 & -0.11 & -0.12 & -0.14 & -0.15 & -0.15 & -0.16 & -0.17 \\
\hline $\begin{array}{l}\text { Real private consumption } p \in \\
\text { Privet }\end{array}$ & 0.00 & 0.69 & 0.34 & 0.09 & -0.09 & -0.20 & -0.27 & -0.32 & -0.34 & -0.35 & -0.37 & & -0.47 \\
\hline $\begin{array}{l}\text { Private investment }(\% \text { of GDP) } \\
\text { Private investment }(0 \text { G tola inv }\end{array}$ & 0.00 & $\begin{array}{l}-0.11 \\
0.16\end{array}$ & -0.10 & -0.09 & -0.07 & -0.05 & $\begin{array}{l}-0.03 \\
-3.93\end{array}$ & $\begin{array}{r}-0.01 \\
-512\end{array}$ & 0.02 & 0.04 & 0.07 & 0.10 & 0.14 \\
\hline $\begin{array}{l}\text { Private investment }(\% \text { of total investment) } \\
\text { Public investment } \% \text { of total public expenditure) }\end{array}$ & $\begin{array}{l}0.00 \\
0.00\end{array}$ & $\begin{array}{r}0.26 \\
-0.40\end{array}$ & $\begin{array}{r}0.09 \\
-0.26\end{array}$ & $\begin{array}{r}-0.75 \\
0.18\end{array}$ & $\begin{array}{c}-1.76 \\
0.68\end{array}$ & $\begin{array}{r}-2.81 \\
1.15\end{array}$ & $\begin{array}{r}-3.93 \\
1.60\end{array}$ & $\begin{array}{l}-5.12 \\
2.02\end{array}$ & $\begin{array}{l}-6.37 \\
2.40\end{array}$ & $\begin{array}{r}-7.64 \\
2.74\end{array}$ & $\begin{array}{r}-8.99 \\
3.05\end{array}$ & $\begin{array}{r}-10.49 \\
3.36\end{array}$ & $\begin{array}{r}-12.30 \\
370\end{array}$ \\
\hline Health (\% of public investment) & 0.00 & 0.00 & $\begin{array}{l}-0.26 \\
0.00\end{array}$ & 0.00 & 0.00 & $\begin{array}{l}1.15 \\
0.00\end{array}$ & $\begin{array}{l}1.60 \\
0.00\end{array}$ & 0.00 & 0.00 & 0.00 & 0.00 & $\begin{array}{l}3.36 \\
0.00\end{array}$ & $\begin{array}{l}3.70 \\
0.00\end{array}$ \\
\hline 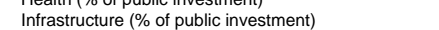 & 0.00 & 0.00 & 0.00 & 0.00 & 0.00 & 0.00 & 0.00 & 0.00 & 0.00 & 0.00 & 0.00 & 0.00 & 0.00 \\
\hline Education (\% of public investment) & 0.00 & 0.00 & 0.00 & 0.00 & 0.00 & 0.00 & 0.00 & 0.00 & 0.00 & 0.00 & 0.00 & 0.00 & 0.00 \\
\hline Other (\% of public investment) & 0.00 & 0.00 & 0.00 & 0.00 & 0.00 & 0.00 & 0.00 & 0.00 & 0.00 & 0.00 & 0.00 & 0.00 & 0.00 \\
\hline Aid (\% of total revenue) & 0.00 & -0.18 & -0.79 & -1.49 & -2.15 & -2.75 & -3.31 & -3.81 & -4.23 & -4.60 & -4.93 & -5.29 & -5.60 \\
\hline Total public investment (\% of aid) & 0.00 & -1.10 & -0.69 & 0.39 & 1.55 & 2.57 & 3.49 & 4.31 & 5.03 & 5.62 & 6.16 & 6.68 & 7.22 \\
\hline Domestic debt (\% of GD & 0.00 & 0.24 & 0.25 & 0.25 & 0.25 & 0.23 & 0.21 & 0.19 & 0.15 & 0.12 & 0.10 & 0.12 & 0.13 \\
\hline $\begin{array}{l}\text { External debt (\% of GD) } \\
\text { Interest navment }\end{array}$ & $\begin{array}{l}0.00 \\
0.00\end{array}$ & $\begin{array}{l}2.34 \\
0.18\end{array}$ & $\begin{array}{l}2.05 \\
0.31\end{array}$ & $\begin{array}{l}1.56 \\
0.41\end{array}$ & $\begin{array}{l}0.99 \\
0.48\end{array}$ & $\begin{array}{l}0.20 \\
0.55\end{array}$ & $\begin{array}{r}-0.64 \\
0.60\end{array}$ & $\begin{array}{r}-1.52 \\
0.65\end{array}$ & $\begin{array}{r}-2.47 \\
0.70\end{array}$ & $\begin{array}{r}-3.40 \\
0.74\end{array}$ & $\begin{array}{r}-4.29 \\
0.79\end{array}$ & $\begin{array}{r}-5.01 \\
0.83\end{array}$ & $\begin{aligned}-5.72 \\
0.87\end{aligned}$ \\
\hline Degree of openness (total trade in $\%$ of GDP) & 0.00 & $\begin{array}{lll}0.187 \\
-4.27\end{array}$ & $\begin{array}{l}-4.31 \\
-45\end{array}$ & -0.41 & $\begin{array}{l}-4.48 \\
-4.55\end{array}$ & -4.81 & $\begin{array}{r}0.00 \\
-5.09\end{array}$ & $\begin{array}{l}0.65 \\
-5.41\end{array}$ & -5.81 & -6.22 & -6.61 & -6.84 & $\begin{array}{c}0.81 \\
-7.09\end{array}$ \\
\hline Educated labor (in $\%$ of population) & 0.00 & 0.00 & 0.00 & 0.00 & 0.00 & $\begin{aligned}-4.01 \\
0.00\end{aligned}$ & 0.00 & 0.00 & $\begin{array}{l}-3.01 \\
0.00\end{array}$ & $\begin{array}{l}-0.22 \\
0.00\end{array}$ & $\begin{array}{r}-0.01 \\
0.00\end{array}$ & $\begin{array}{l}-0.04 \\
0.00\end{array}$ & 0.00 \\
\hline
\end{tabular}


Table 8

Niger: 10 Percent Decrease in Tariff Rate, Increase in Indirect Tax Rate to 4.4 Percent, 2003-15

\begin{tabular}{|c|c|c|c|c|c|c|c|c|c|c|c|c|c|}
\hline & \multicolumn{13}{|c|}{ Years } \\
\hline & 2003 & 2004 & 2005 & 2006 & 2007 & 2008 & 2009 & 2010 & 2011 & 2012 & 2013 & 2014 & 2015 \\
\hline \multicolumn{14}{|l|}{ Real Sector (in billions of current CFA francs) } \\
\hline Total supply of goods and services & 0.00 & -4.09 & -4.15 & -4.15 & -4.18 & -4.23 & -4.19 & -4.28 & -4.35 & -4.46 & -4.66 & -4.80 & -4.96 \\
\hline $\begin{array}{l}\text { Gross domestic product at factor cost } \\
\text { faiffs) }\end{array}$ & 0.00 & -0.09 & -0.40 & -0.65 & -0.87 & -1.07 & -1.02 & -1.20 & -1.27 & -1.36 & -1.58 & -1.72 & -1.85 \\
\hline $\begin{array}{l}\text { Imports of goods and NFS (inclusive of tariffs) } \\
\text { Totat lexpenditure on goods and services }\end{array}$ & 0.00 & $\begin{array}{l}-16.35 \\
-408\end{array}$ & -15.91 & -15.51 & -15.31 & -15.23 & -15.60 & -15.75 & -16.06 & -16.49 & -16.79 & -17.16 & -17.62 \\
\hline $\begin{array}{l}\text { Totalal expenditure on goods and services } \\
\text { Total consumption }\end{array}$ & $\begin{array}{l}0.00 \\
0.00\end{array}$ & $\begin{array}{r}-4.08 \\
-4.11\end{array}$ & $\begin{array}{l}-4.16 \\
-3.71\end{array}$ & $\begin{array}{l}-4.14 \\
-3.47\end{array}$ & $\begin{array}{l}-4.17 \\
-.34\end{array}$ & 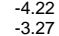 & $\begin{array}{l}-4.19 \\
-3.12\end{array}$ & $\begin{array}{l}-4.27 \\
-312\end{array}$ & $\begin{array}{l}-4.35 \\
-313\end{array}$ & $\begin{array}{l}-4.47 \\
-3.17\end{array}$ & $\begin{array}{l}-4.67 \\
-331\end{array}$ & $\begin{array}{l}-4.81 \\
-3.39\end{array}$ & $\begin{array}{l}-4.98 \\
-350\end{array}$ \\
\hline Private consumption & 0.00 & $\begin{array}{l}-4.11 \\
-4.76\end{array}$ & -4.26 & $\begin{array}{l}-0.4 t \\
-3.97\end{array}$ & $\begin{array}{l}-3.84 \\
-3.80\end{array}$ & $\begin{array}{l}-3.27 \\
-3.71\end{array}$ & $\begin{array}{l}-3.12 \\
-3.55 \\
\end{array}$ & $\begin{array}{ll}-3.12 \\
-3.54\end{array}$ & $\begin{array}{l}-3.13 \\
-3.54\end{array}$ & $\begin{array}{l}-3.17 \\
-3.58\end{array}$ & $\begin{array}{l}-3.31 \\
-3.71\end{array}$ & $\begin{array}{r}-3.39 \\
-3.78\end{array}$ & $\begin{array}{r}-3.50 \\
-3.89\end{array}$ \\
\hline Public spending on goods and services & 0.00 & -0.50 & -0.66 & -0.72 & -0.80 & -0.87 & -0.75 & $\begin{array}{l}-0.34 \\
-0.32\end{array}$ & -0.86 & $\begin{array}{l}-0.50 \\
-0.92\end{array}$ & $\begin{array}{l}-0.11 \\
-1.09\end{array}$ & -1.19 & $\begin{array}{l}-3.89 \\
-1.31\end{array}$ \\
\hline Total investment & 0.00 & -6.54 & -8.34 & 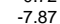 & -7.10 & -6.33 & -5.48 & -4.78 & -3.96 & -3.22 & -2.53 & -1.68 & $\begin{array}{l}-1.31 \\
-0.76\end{array}$ \\
\hline Private investment & 0.00 & -5.80 & -5.84 & -6.05 & -6.07 & -6.00 & -5.81 & -5.67 & -5.49 & -5.29 & -5.13 & -4.87 & -4.62 \\
\hline Public investment & 0.00 & -7.58 & -12.38 & -10.99 & -9.11 & -7.05 & -4.64 & -2.21 & 1.11 & 4.78 & 9.45 & 16.34 & 27.47 \\
\hline Exports of goods and NFS & 0.00 & -2.53 & -4.71 & -6.52 & -8.05 & -9.42 & -10.70 & -11.90 & -13.06 & -14.18 & -15.26 & -16.34 & -17.40 \\
\hline Gross domestic product at market prices & 0.00 & $\begin{array}{c}-0.50 \\
-0.59\end{array}$ & $\begin{array}{l}-0.64 \\
-0.59\end{array}$ & -0.72 & -0.80 & -0.88 & -0.75 & -0.84 & -0.85 & -0.91 & -1.09 & -1.18 & -1.30 \\
\hline \multicolumn{14}{|l|}{ Poverty rate } \\
\hline $\begin{array}{l}\text { Poverty rate } \\
\text { Ravallion's (2004) adjusted elasticity (Gini = 50.5) }\end{array}$ & 0.00 & -0.67 & -1.05 & -1.25 & -1.31 & -1.28 & -1.21 & -1.08 & -0.93 & -0.77 & -0.59 & -0.40 & -0.20 \\
\hline Consumption per capita growth elasticity of -0.5 & 0.00 & -0.30 & -0.47 & -0.56 & -0.59 & -0.58 & -0.55 & -0.49 & -0.43 & -0.36 & -0.27 & -0.19 & -0.09 \\
\hline & & & & -1.11 & & & -1.07 & -0.96 & -0.83 & -0.69 & -0.53 & -0.36 & 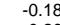 \\
\hline Consumption per capita growth elasticity of -1.5 & 0.00 & -0.89 & -1.39 & -1.65 & -1.73 & -1.68 & -1.58 & -1.41 & -1.22 & -1.00 & -0.77 & -0.51 & -0.26 \\
\hline \multicolumn{14}{|l|}{$\begin{array}{l}\text { External Sector (\% of GDP) } \\
\text { Current account }\end{array}$} \\
\hline Current account & 0.00 & 1.61 & 1.10 & 0.65 & 0.32 & 0.07 & -0.03 & -0.19 & -0.28 & -0.35 & -0.44 & -0.52 & -0.58 \\
\hline Trade balance & 0.00 & 1.65 & 1.15 & 0.70 & 0.38 & 0.12 & 0.01 & -0.14 & -0.24 & -0.30 & -0.40 & -0.47 & -0.53 \\
\hline Exports of goods and NFS & 0.00 & -0.31 & -0.63 & -0.89 & -1.10 & -1.27 & -1.45 & -1.57 & -1.71 & -1.83 & -1.93 & -2.04 & -2.15 \\
\hline $\begin{array}{l}\text { Imports of goods and NFS } \\
\text { Private unrequited transfers }\end{array}$ & $\begin{array}{l}0.00 \\
0.00\end{array}$ & $\begin{array}{r}-1.96 \\
0.00\end{array}$ & $\begin{array}{r}-1.78 \\
0.00\end{array}$ & $\begin{array}{r}-1.60 \\
0.00\end{array}$ & $\begin{array}{r}-1.48 \\
001\end{array}$ & $\begin{array}{r}-1.39 \\
0.01\end{array}$ & $\begin{array}{r}-1.46 \\
-0.00\end{array}$ & $\begin{array}{l}-1.43 \\
-001\end{array}$ & -1.47 & -1.52 & $\begin{array}{r}-1.53 \\
0.1\end{array}$ & -1.57 & -1.62 \\
\hline $\begin{array}{l}\text { Private unrequited transfers } \\
\text { Income (net) }\end{array}$ & $\begin{array}{l}0.00 \\
0.00\end{array}$ & $\begin{array}{l}0.00 \\
0.00\end{array}$ & $\begin{array}{r}0.00 \\
-0.01\end{array}$ & $\begin{array}{r}0.00 \\
-0.01\end{array}$ & $\begin{array}{c}0.01 \\
-0.01\end{array}$ & $\begin{array}{r}0.01 \\
-0.01\end{array}$ & $\begin{array}{r}0.00 \\
-0.01\end{array}$ & $\begin{array}{l}0.01 \\
0.00\end{array}$ & $\begin{array}{l}0.01 \\
0.00\end{array}$ & $\begin{array}{l}0.01 \\
0.00\end{array}$ & $\begin{array}{l}0.01 \\
0.00\end{array}$ & $\begin{array}{l}0.01 \\
0.00\end{array}$ & 0.01 \\
\hline Public & 0.00 & $\begin{array}{r}0.00 \\
-0.01\end{array}$ & $\begin{array}{l}-0.01 \\
-0.01\end{array}$ & $\begin{array}{l}-0.01 \\
-0.01\end{array}$ & $\begin{array}{l}-0.01 \\
-0.01 \\
\end{array}$ & $\begin{array}{l}-0.01 \\
-0.01\end{array}$ & $\begin{array}{l}-0.01 \\
-0.01\end{array}$ & -0.01 & $\begin{array}{r}-0.01 \\
-0.01\end{array}$ & 0.00 & 0.00 & 0.00 & $\begin{array}{l}0.00 \\
0.00\end{array}$ \\
\hline Private & 0.00 & 0.00 & 0.00 & 0.00 & 0.00 & $\begin{aligned}-0.01 \\
0.00\end{aligned}$ & 0.00 & 0.00 & $\begin{array}{l}-0.01 \\
0.00\end{array}$ & 0.00 & 0.00 & 0.00 & 0.00 \\
\hline Aid, total & 0.00 & 0.00 & 0.00 & 0.00 & 0.00 & 0.00 & 0.00 & 0.00 & 0.00 & 0.00 & 0.00 & 0.00 & 0.00 \\
\hline Other current account flows (net) & 0.00 & -0.04 & -0.04 & -0.05 & -0.05 & -0.05 & -0.04 & -0.05 & -0.05 & -0.05 & -0.05 & -0.06 & -0.06 \\
\hline Capital account & 0.00 & 0.32 & 0.06 & -0.01 & -0.04 & -0.07 & -0.09 & -0.11 & -0.11 & -0.11 & -0.10 & -0.10 & -0.09 \\
\hline Private borrowing & 0.00 & 0.00 & 0.00 & 0.00 & 0.00 & 0.00 & 0.00 & 0.00 & 0.00 & 0.00 & 0.00 & 0.00 & 0.00 \\
\hline $\begin{array}{l}\text { Public borrowing } \\
\text { Errors and omissions }\end{array}$ & $\begin{array}{l}0.00 \\
0.00\end{array}$ & $\begin{array}{l}0.32 \\
0.00\end{array}$ & $\begin{array}{l}0.06 \\
0.00\end{array}$ & $\begin{array}{c}-0.01 \\
0.00\end{array}$ & $\begin{array}{r}-0.05 \\
0.00\end{array}$ & $\begin{array}{r}-0.07 \\
0.00\end{array}$ & $\begin{array}{l}-0.09 \\
0.00\end{array}$ & $\begin{array}{c}-0.11 \\
0.00\end{array}$ & $\begin{array}{r}-0.11 \\
0.00\end{array}$ & $\begin{array}{r}-0.11 \\
0.00\end{array}$ & $\begin{array}{l}-0.11 \\
000\end{array}$ & $\begin{array}{r}-0.10 \\
0.00\end{array}$ & -0.09 \\
\hline \\
\hline $\begin{array}{l}\text { Tovernmentsector(\% or ordr) } \\
\text { Total revenue (including grants) }\end{array}$ & 0.00 & -0.29 & -0.15 & 0.01 & 0.14 & 0.25 & 0.33 & 0.41 & 0.46 & 0.50 & 0.53 & 0.56 & 0.59 \\
\hline Domestic taxes & 0.00 & 2.49 & 2.57 & 2.62 & 2.66 & 2.68 & 2.69 & 2.70 & 2.71 & 2.72 & 2.72 & 2.72 & 2.73 \\
\hline Direct taxes & 0.00 & 0.00 & 0.00 & 0.00 & 0.00 & -0.01 & -0.01 & -0.01 & -0.01 & 0.00 & 0.00 & 0.00 & 0.00 \\
\hline $\begin{array}{l}\text { Indirect taxes } \\
\text { nd }\end{array}$ & 0.00 & 2.48 & 2.57 & 2.62 & 2.66 & 2.69 & 2.70 & 2.71 & 2.72 & 2.72 & 2.73 & 2.73 & 2.73 \\
\hline $\begin{array}{l}\text { Indirect taxes on imports } \\
\text { Forign aid (grants) }\end{array}$ & $\begin{array}{l}0.00 \\
0.00\end{array}$ & $\begin{array}{r}-2.78 \\
0.00\end{array}$ & $\begin{array}{r}-2.71 \\
0.00\end{array}$ & $\begin{array}{c}-2.61 \\
0.00\end{array}$ & $\begin{aligned}-2.52 \\
0.00\end{aligned}$ & $\begin{array}{r}-2.43 \\
0.00\end{array}$ & $\begin{array}{l}-2.36 \\
0.00\end{array}$ & $\begin{array}{r}-2.30 \\
0.00\end{array}$ & $\begin{array}{r}-2.25 \\
0.00\end{array}$ & $\begin{array}{l}-2.22 \\
0.00\end{array}$ & $\begin{array}{r}-2.19 \\
0.00\end{array}$ & $\begin{array}{r}-2.16 \\
0.00\end{array}$ & $\begin{array}{r}-2.14 \\
0.00\end{array}$ \\
\hline Total expenditure & 0.00 & $\begin{array}{r}0.00 \\
-0.43\end{array}$ & $\begin{array}{r}0.54 \\
-0.54\end{array}$ & -0.45 & -0.36 & -0.28 & -0.21 & $\begin{array}{l}-0.15 \\
-0.00\end{array}$ & $\begin{array}{r}-0.00 \\
-0.10\end{array}$ & -0.05 & $\begin{array}{c}0.001 \\
-0.00\end{array}$ & 0.03 & $\begin{array}{l}0.00 \\
0.07\end{array}$ \\
\hline $\begin{array}{l}\text { orate expeniture } \\
\text { Spending on goods and services }\end{array}$ & 0.00 & 0.00 & 0.00 & 0.00 & 0.00 & 0.00 & 0.00 & 0.00 & 0.00 & 0.00 & 0.00 & 0.00 & 0.00 \\
\hline Wages and salaries & 0.00 & -0.18 & -0.17 & -0.17 & -0.16 & -0.15 & -0.15 & -0.14 & -0.13 & -0.12 & -0.11 & -0.10 & -0.09 \\
\hline Investment & 0.00 & -0.26 & -0.38 & -0.30 & -0.21 & -0.14 & -0.07 & -0.02 & 0.03 & 0.06 & 0.10 & 0.13 & 0.16 \\
\hline Interest payments & 0.00 & 0.01 & 0.01 & 0.01 & 0.01 & 0.01 & 0.01 & 0.01 & 0.01 & 0.01 & 0.00 & 0.00 & 0.00 \\
\hline Domestic def & 0.00 & 0.00 & 0.00 & 0.00 & 0.00 & 0.00 & 0.00 & 0.00 & 0.00 & 0.00 & 0.00 & 00 & $0.00>>2>0$ \\
\hline $\begin{array}{l}\text { Foreign debt } \\
\end{array}$ & 0.00 & 0.01 & 0.01 & 0.01 & 0.01 & 0.01 & 0.01 & 0.01 & 0.01 & 0.00 & 0.00 & 0.00 & 0.00 \\
\hline $\begin{array}{l}\text { Overall fiscal balance } \\
\text { Totat financing }\end{array}$ & $\begin{array}{l}0.00 \\
0.00\end{array}$ & $\begin{array}{r}-0.32 \\
0.32\end{array}$ & $\begin{array}{r}-0.06 \\
0.06\end{array}$ & $\begin{array}{r}0.01 \\
-0.01\end{array}-1$ & $\begin{array}{r}0.05 \\
-0.05\end{array}$ & $\begin{array}{r}0.07 \\
-0.07\end{array}$ & $\begin{array}{c}0.09 \\
-0.09\end{array}$ & $\begin{aligned} 0.11 \\
-0.11\end{aligned}$ & $\begin{array}{r}0.11 \\
-0.11\end{array}$ & $\begin{array}{r}0.11 \\
-0.11\end{array}$ & 0.11 & 0.10 & 0.09 \\
\hline $\begin{array}{l}\text { Totall inancing } \\
\text { Foreign financing }\end{array}$ & $\begin{array}{l}0.00 \\
0.00\end{array}$ & $\begin{array}{l}0.32 \\
0.32\end{array}$ & $\begin{array}{l}0.06 \\
0.06\end{array}$ & $\begin{array}{l}-0.01 \\
-0.01\end{array}$ & $\begin{array}{l}-0.05 \\
-0.05\end{array}$ & $\begin{array}{l}-0.07 \\
-0.07\end{array}$ & $\begin{array}{l}-0.09 \\
-0.09\end{array}$ & $\begin{array}{l}-0.11 \\
-011\end{array}$ & $\begin{array}{l}-0.11 \\
-0.11\end{array}$ & $\begin{array}{l}-0.11 \\
-0.11\end{array}$ & $\begin{array}{l}-0.11 \\
-0.11\end{array}$ & -0.10 & -0.09 \\
\hline Domestic borrowing & 0.00 & 0.00 & 0.00 & 0.00 & 0.00 & 0.00 & 0.00 & 0.00 & 0.00 & 0.00 & 0.00 & 0.00 & 0.00 \\
\hline \multicolumn{14}{|l|}{ Prices and Real Exchange Rate } \\
\hline GDP at factor & 0.00 & -0.09 & -0.30 & -0.24 & -0.20 & -0.17 & 0.08 & -0.14 & -0.03 & -0.06 & -0.18 & -0.11 & -0.11 \\
\hline Composite good price (after indirect taxes, $\%$ change) & 0.00 & -3.31 & 0.05 & 0.08 & 0.10 & 0.15 & 0.27 & 0.19 & 0.21 & 0.20 & 0.13 & 0.21 & 0.20 \\
\hline Real exchange rate (\% change) & 0.00 & 3.31 & -0.05 & -0.08 & -0.10 & -0.15 & -0.27 & -0.19 & -0.21 & -0.20 & -0.13 & -0.21 & -0.20 \\
\hline \multicolumn{14}{|l|}{ Memorandum items } \\
\hline Real GDP per capita at factor cost (\% change) & 0.00 & 0.00 & -0.01 & -0.01 & -0.02 & -0.03 & -0.04 & -0.04 & -0.04 & -0.04 & -0.03 & -0.03 & -0.03 \\
\hline Real GDP per capita at market prices (\% change) & 0.00 & 2.76 & -0.20 & -0.16 & -0.18 & -0.24 & -0.13 & -0.29 & -0.23 & -0.25 & -0.32 & -0.32 & -0.31 \\
\hline Real disposable income per capita (\% change) & 0.00 & 3.00 & -0.36 & -0.32 & -0.32 & -0.36 & -0.21 & -0.36 & -0.28 & -0.29 & -0.35 & -0.35 & -0.33 \\
\hline Private savir & 0.00 & 0.02 & 0.01 & -0.01 & -0.02 & -0.03 & -0.04 & -0.05 & -0.05 & -0.05 & -0.06 & -0.06 & -0.06 \\
\hline capita (\% change) & 0.00 & 0.94 & 0.54 & 0.29 & 0.11 & -0.03 & -0.09 & -0.16 & -0.21 & -0.23 & -0.26 & -0.29 & -0.30 \\
\hline Private investmen & 0.00 & -0.27 & -0.27 & -0.27 & -0.26 & -0.25 & -0.24 & -0.23 & & -0.19 & -0.17 & -0.15 & -0.13 \\
\hline $\begin{array}{l}\text { Private investment (\% of total investment) } \\
\text { Pation }\end{array}$ & 0.00 & 0.46 & 1.69 & 1.25 & 0.73 & 0.24 & -0.25 & -0.70 & -1.22 & -1.69 & -2.19 & -2.76 & -3.42 \\
\hline $\begin{array}{l}\text { Public investment } \% \text { of total pubbic expenditure) } \\
\text { Health (\% of public investment) }\end{array}$ & $\begin{array}{l}0.00 \\
0.00\end{array}$ & $\begin{array}{l}-0.85 \\
0.00\end{array}$ & $\begin{array}{r}-1.37 \\
0.00\end{array}$ & $\begin{array}{r}-1.10 \\
0.00\end{array}$ & $\begin{array}{r}-0.79 \\
0.00\end{array}$ & $\begin{array}{r}-0.51 \\
0.00\end{array}$ & $\begin{array}{l}-0.26 \\
0.00\end{array}$ & $\begin{array}{r}-0.05 \\
0.00\end{array}$ & $\begin{array}{l}0.16 \\
0.00\end{array}$ & $\begin{array}{l}0.33 \\
0.00\end{array}$ & $\begin{array}{l}0.49 \\
0.00\end{array}$ & $\begin{array}{l}0.64 \\
0.00\end{array}$ & $\begin{array}{l}0.79 \\
0.00\end{array}$ \\
\hline $\begin{array}{l}\text { Healith (\% of public investment) } \\
\text { Infrastructure (\% of public investment) }\end{array}$ & $\begin{array}{l}0.00 \\
0.00\end{array}$ & 0.00 & $\begin{array}{l}0.00 \\
0.00\end{array}$ & $\begin{array}{l}0.00 \\
0.00\end{array}$ & $\begin{array}{l}0.00 \\
0.00\end{array}$ & 0.00 & $\begin{array}{l}0.00 \\
0.00\end{array}$ & $\begin{array}{l}0.00 \\
0.00\end{array}$ & $\begin{array}{l}0.00 \\
0.00\end{array}$ & $\begin{array}{l}0.00 \\
0.00\end{array}$ & $\begin{array}{l}0.00 \\
0.00\end{array}$ & $\begin{array}{l}0.00 \\
0.00\end{array}$ & 0.00 \\
\hline $\begin{array}{l}\text { Intrastructure } \\
\text { Education (\% of public investment) }\end{array}$ & 0.00 & 0.00 & 0.00 & 0.00 & 0.00 & 0.00 & 0.00 & 0.00 & 0.00 & 0.00 & 0.00 & 0.00 & 0.00 \\
\hline Other (\% of public investment) & 0.00 & 0.00 & 0.00 & 0.00 & 0.00 & 0.00 & 0.00 & 0.00 & 0.00 & 0.00 & 0.00 & 0.00 & 0.00 \\
\hline Aid (\% of total revenue) & 0.00 & 0.80 & 0.41 & -0.04 & -0.42 & -0.77 & -1.04 & -1.31 & -1.50 & -1.65 & -1.79 & -1.93 & -2.02 \\
\hline estment ( $\%$ of aid) & 0.00 & -2.43 & -3.54 & -2.79 & -1.98 & -1.28 & -0.69 & -0.21 & 0.25 & 0.60 & 0.91 & 1.20 & 1.47 \\
\hline Domestic debt $(\%$ of G & 0.00 & 0.04 & 0.05 & 0.05 & 0.06 & 0.06 & 0.04 & 0.05 & 0.05 & 0.06 & 0.08 & 0.09 & 0.10 \\
\hline External debt (\% of GDP) & 0.00 & 0.71 & 0.85 & 0.87 & 0.85 & 0.79 & 0.57 & 0.51 & 0.38 & 0.30 & 0.31 & 0.27 & 0.25 \\
\hline $\begin{array}{l}\text { Interest payment on external public debt (\% of exports) } \\
\text { Dearee of openness (totalat trade in } \% \text { of GDP) }\end{array}$ & $\begin{array}{l}0.00 \\
0.00\end{array}$ & $\begin{array}{l}0.17 \\
-506\end{array}$ & $\begin{array}{r}0.35 \\
-5.12\end{array}$ & $\begin{array}{r}0.49 \\
-510\end{array}$ & $\begin{array}{l}0.61 \\
.509\end{array}$ & $\begin{array}{r}0.72 \\
-509\end{array}$ & 0.82 & 0.92 & $\begin{array}{r}1.02 \\
-5.43\end{array}$ & $\begin{array}{l}1.11 \\
-5.57\end{array}$ & $\begin{array}{l}1.21 \\
-565\end{array}$ & $\begin{array}{r}1.30 \\
-577-200\end{array}$ & $\begin{array}{r}1.39 \\
-5.92\end{array}$ \\
\hline $\begin{array}{l}\text { Degree of openness (total trade in \% of GDP) } \\
\text { Educated labor (in } \% \text { of population) }\end{array}$ & 0.00 & $\begin{array}{l}-5.00 \\
0.00\end{array}$ & $\begin{array}{r}-5.12 \\
0.00\end{array}$ & $\begin{array}{r}-5.10 \\
0.00\end{array}$ & $\begin{aligned}-5.09 \\
0.00\end{aligned}$ & $\begin{array}{r}-5.09 \\
0.00\end{array}$ & $\begin{array}{l}-5.27 \\
-0.00\end{array}$ & $\begin{array}{l}-5.30 \\
0.00\end{array}$ & $\begin{array}{r}-5.43 \\
0.00\end{array}$ & $\begin{array}{l}-5.00 \\
0.00\end{array}$ & $\begin{array}{r}-5.65 \\
0.00\end{array}$ & 0.00 & $\begin{array}{r}-5.92 \\
0.00\end{array}$ \\
\hline
\end{tabular}

